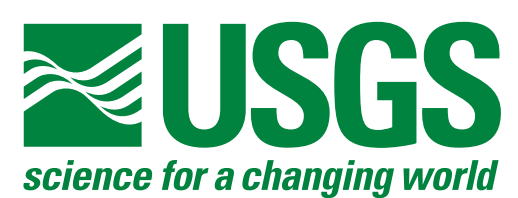

\title{
Survival of Bacterial Indicators and the Functional Diversity of Native Microbial Communities in the Floridan Aquifer System, South Florida
}

By John T. Lisle

Open-File Report 2014-1011

U.S. Department of the Interior

U.S. Geological Survey 


\section{U.S. Department of the Interior \\ SALLY JEWELL, Secretary}

\section{U.S. Geological Survey \\ Suzette M. Kimball, Acting Director}

U.S. Geological Survey, Reston, Virginia: 2014

For more information on the USGS-the Federal source for science about the Earth, its natural and living resources, natural hazards, and the environment-visit http://www.usgs.gov or call 1-888-ASK-USGS

For an overview of USGS information products, including maps, imagery, and publications, visit $h$ ttp://www.usgs.gov/pubprod

To order this and other USGS information products, visit http://store.usgs.gov

Any use of trade, firm, or product names is for descriptive purposes only and does not imply endorsement by the U.S. Government.

Although this information product, for the most part, is in the public domain, it also may contain copyrighted materials as noted in the text. Permission to reproduce copyrighted items must be secured from the copyright owner.

Suggested citation:

Lisle, J.T., 2014, Survival of Bacterial Indicators and the Functional Diversity of Native Microbial Communities in the Floridan Aquifer System, South Florida: U.S. Geological Survey Open-File Report 2014-1011, 70 p., http://dx.doi.org/10.3133/ofr20141011

ISSN 2331-1258 (online) 


\section{Contents}

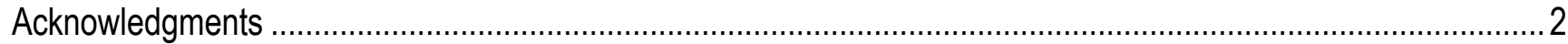

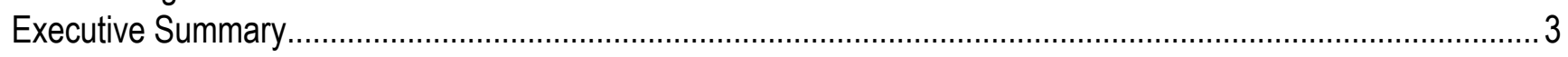

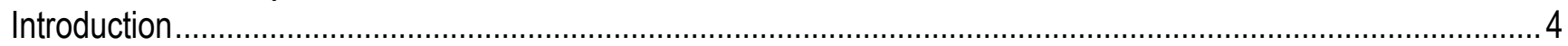

Problem Statement

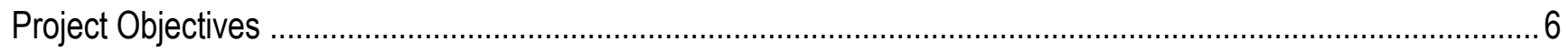

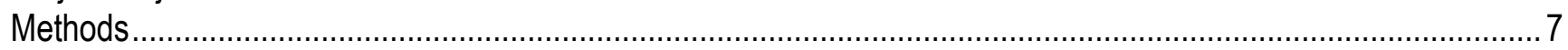

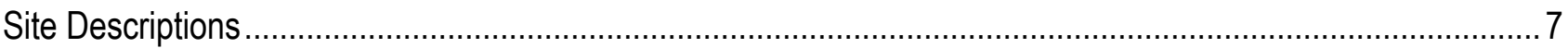

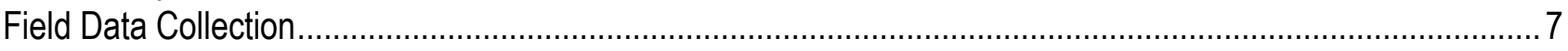

Geochemical and Nutrient Sample Collection and Analyses .................................................................... 7

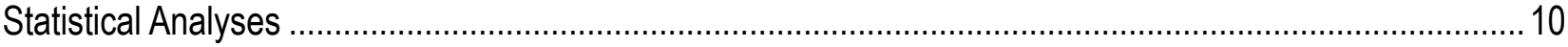

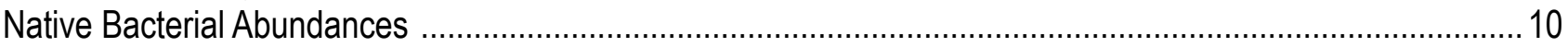

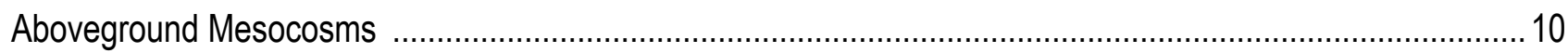

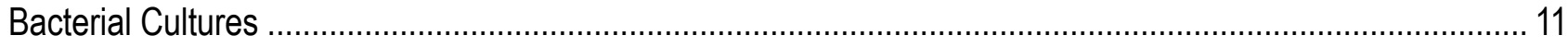

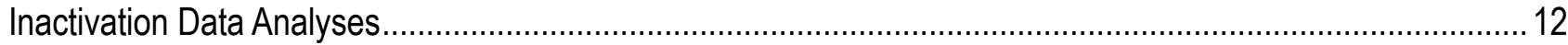

Quantification and Characterization of Dissolved Organic Carbon (DOC) ................................................... 12

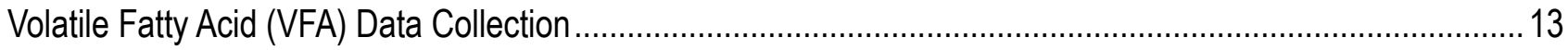

Bacterial Respiration and Carbon Turnover and Carbon Dioxide Production Rates ......................................13

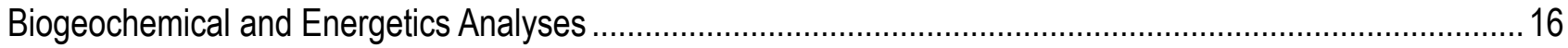

Microbial Community Diversity Sample Collection and Analyses .............................................................. 18

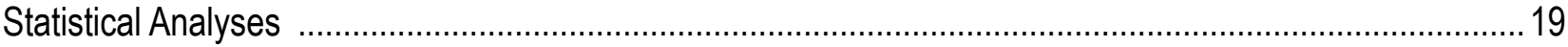

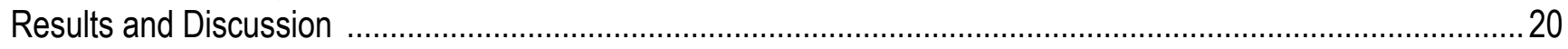

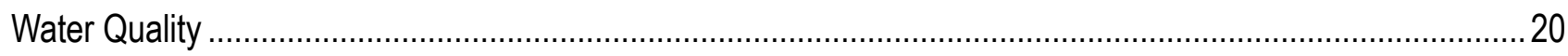

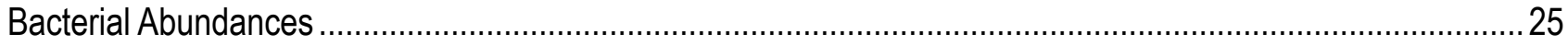

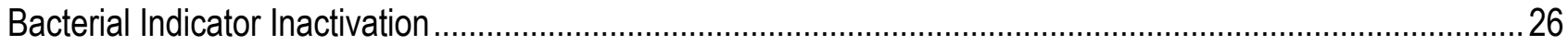

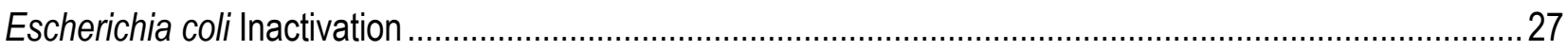

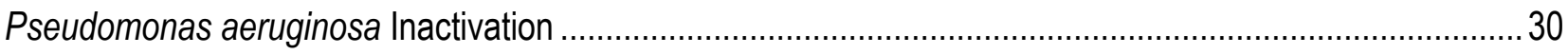

Relevance of Escherichia coli Inactivation Rates in the Upper Floridan aquifer .........................................33

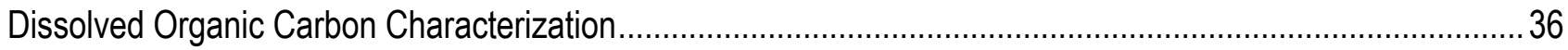

Bacterial Utilization and Turnover of Native Carbon .................................................................................... 37

Microbial Energetics and Sustainability in the Upper Floridan Aquifer .......................................................... 39

Free Energy Yields for Energetically Favorable Biogeochemical Reactions............................................. 40

Chemical Affinities for Energetically Favorable Biogeochemical Reactions ............................................... 41

Free Energy Flux Rates for Energetically Favorable Biogeochemical Reactions .....................................4 43

Functional Bacterial Diversity and the Relationship to Geochemistry in the Upper Floridan Aquifer ................48

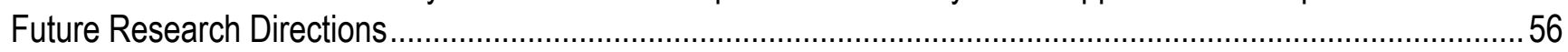

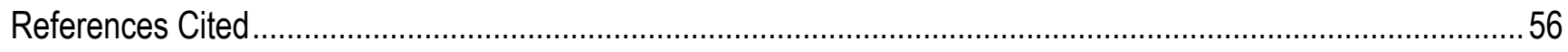

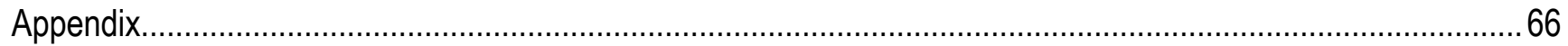




\section{Figures}

1. Aerial photograph showing sampling-site locations, indicated by green triangles. .................................... 8

2. Graph showing principal component analysis of field data from the six sampling sites ..............................20

3. Graph showing principal component analysis of ionic species data from the six sampling sites .................20

4. Graph showing principal component analysis of nutrient data from the six samplng sites .........................21

5. Graph showing principal component analysis of carbon substrate data from the six sampling sites...........21

6. Graph showing principal component analysis of terminal electron acceptor data from the six sampling sites

7. Graph showing principal component analysis of reactant data from the six sampling sites for the thermodynamically favorable biogeochemical reactions

8. Graphs showing Escherichia coli decay rates for the 42U and 42L sampling sites ...................................28

9. Graphs showing Escherichia coli decay rates for the $15 \mathrm{U}$ and $15 \mathrm{M}$ sampling sites ...................................29

10. Graph showing Escherichia coli decay rates for the MZ1 and MZ3 sampling sites ....................................30

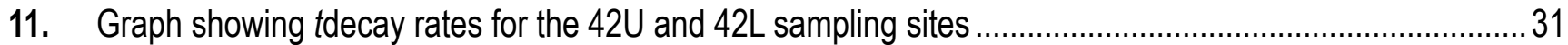

12. Graph showing Pseudomonas aeruginosa decay rates for the $15 \mathrm{U}$ and $15 \mathrm{M}$ sampling sites .....................32

13. Graph showing Pseudomonas aeruginosa decay rates from the MZ1 and MZ3 sampling sites .................33

14. Graph showing chemical affinities of the thermodynamically favorable biogeochemical reactions ..............44

15. Comparisons between the free energy of reaction $(\Delta G)$, free energy flux (FEF), and maximum acquisition rate (MAR) data from the six sampling sites

16. Biogeochemical processes that most likely dominate in the south region of the Upper Floridan aquifer..... 48

17. Bacterial diversity distributions from the six sampling sites.

\section{Tables}

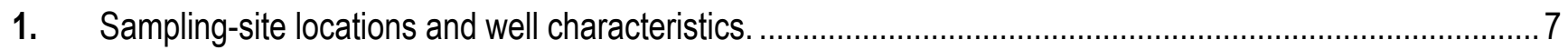

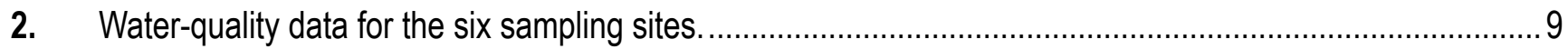

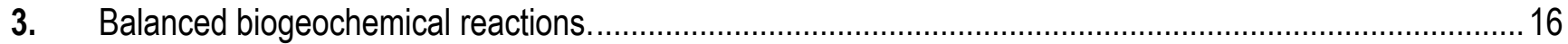

4. Sample volumes for bacterial diversity analyses samples from the six sampling sites............................... 18

5. Principal component analyses eigenvector data for the six sampling sites...............................................2

6. Principal component analyses percent variance per axis data for the six sampling sites.............................24

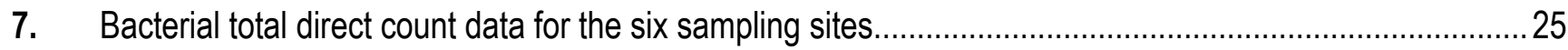

8. Biphasic inactivation rate curve data for Escherichia coli and Pseudomonas aeruginosa from the

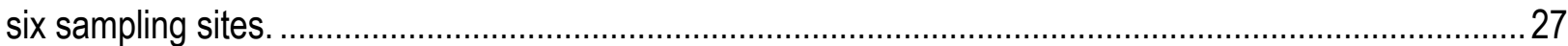

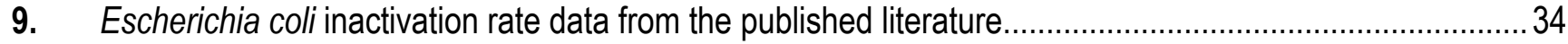

10. The estimated storage time to achieve $1.0 \mathrm{CFU}$ in the recovered water at the six sampling sites..............35

11. Dissolved organic carbon and carbon fluorescent index data for the six sampling sites. ...........................36

12. ${ }^{14} \mathrm{C}$-acetate turnover and utilization rate data for the native bacterial community at the six sampling sites. 38

13. ${ }^{3} \mathrm{H}$-leucine-based bacterial production rates at the six sampling sites. 
14. Bacterial growth efficiency data for the six sampling sites.

15. Free energy flux and maximum acquition rate data for the $42 \mathrm{U}$ and $42 \mathrm{~L}$ sampling sites............................42

16. Free energy flux and maximum acquition rate data for the $15 \mathrm{U}$ and $15 \mathrm{M}$ sampling sites...........................42

17. Free energy flux and maximum acquition rate data for the MZ1 and MZ3 sampling sites..........................42

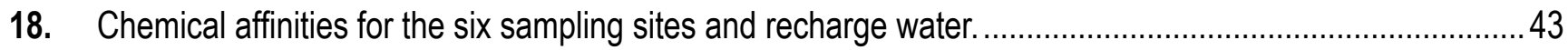

19. Free energy flux and maximum acquition rate data for the recharge water. ............................................4 45

20. Comparisons between the measured and predicted acetate turnover rates in the six sampling sites.........49

21. Bacterial diversity in the six sampling sites and between sampling events............................................50

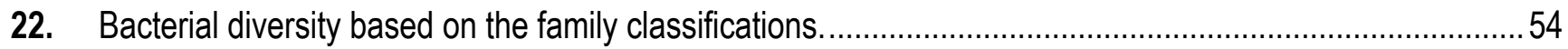

23. Likely biogeochemical processes based on bacterial diversity in all of the sampling sites.........................55

\section{Appendix Figures}

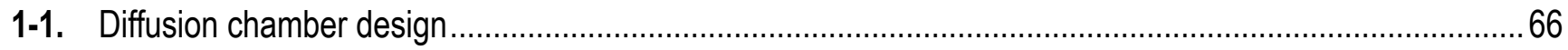

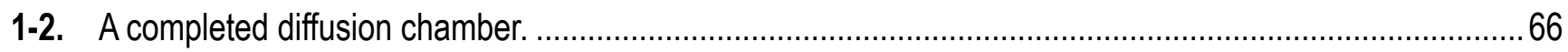

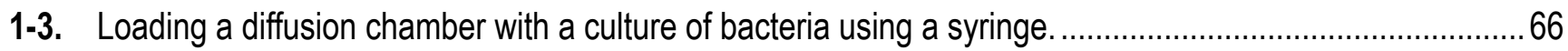

1-4. A diffusion chamber containing the bacterial culture suspended from a cap from the stainless steel

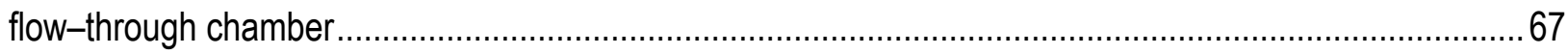

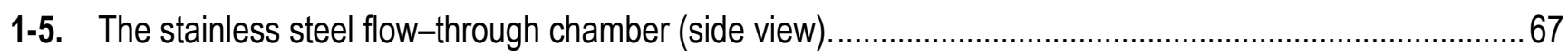

1-6. The stainless steel flow-through chamber showing the baffles and positions of the diffusion chambers (top view).

1-7. The stainless steel flow-through chamber showing the inert polymer top into which the caps that hold the diffusion chambers are inserted (top view).

1-8. The stainless steel flow-through chamber showing the silicon gasket that seals the connection between the polymer top and the stainless steel chamber (side view).

1-9. The complete stainless steel flow-through chamber with diffusion chambers inserted (side view).

1-10. The outer flow-through chamber, flow rate controls and connections for the multiprobe attachment fittings.

1-11. The outer flow-through chamber flow rate controls and multiprobe attachment fittings (rear view) ........... 70

1-12. The outer flow-through chamber discharge and multiprobe fittings...

1-13. An empty outer flow-through chamber showing the connections for the stainless steel flow-through chamber that contains the diffusion chambers.

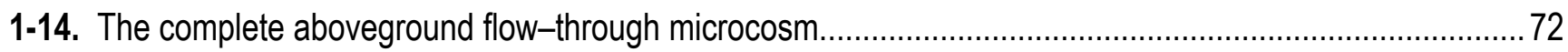

1-15. The above ground flow through microcosm in the field. 


\section{Conversion Factors}

\begin{tabular}{|c|c|c|}
\hline Multiply & By & To obtain \\
\hline \multicolumn{3}{|c|}{ Length } \\
\hline nanometer (nm) & 0.00000003937 & inch (in.) \\
\hline micrometer $(\mu \mathrm{m})$ & 0.00003937 & inch (in.) \\
\hline millimeter (mm) & 0.03937 & inch (in.) \\
\hline centimeter $(\mathrm{cm})$ & 0.394 & inch (in.) \\
\hline meter (m) & 3.281 & foot $(\mathrm{ft})$ \\
\hline meter (m) & 1.094 & yard (yd) \\
\hline kilometer $(\mathrm{km})$ & 0.621 & mile (mi) \\
\hline \multicolumn{3}{|c|}{ Volume } \\
\hline liter (L) & 33.82 & ounce, fluid (fl. oz) \\
\hline liter (L) & 2.113 & pint (pt) \\
\hline liter (L) & 1.057 & quart (qt) \\
\hline liter $(\mathrm{L})$ & 0.264 & gallon (gal) \\
\hline \multicolumn{3}{|c|}{ Flow velocity } \\
\hline meter per day $(\mathrm{m} / \mathrm{d})$ & 3.281 & foot per day (ft/d) \\
\hline \multicolumn{3}{|c|}{ Flow rate } \\
\hline milliliter per minute $(\mathrm{mL} / \mathrm{min})$ & 0.0002642 & gallon per minute (gal/min) \\
\hline liter per minute $(\mathrm{L} / \mathrm{min})$ & 0.2642 & gallon per minute (gal/min) \\
\hline liter per day $(\mathrm{L} / \mathrm{d})$ & 0.2642 & gallon per day (gal/d) \\
\hline \multicolumn{3}{|c|}{ Mass } \\
\hline $\operatorname{gram}(\mathrm{g})$ & 0.03527 & ounce, avoirdupois (oz) \\
\hline \multicolumn{3}{|c|}{ Energy } \\
\hline joule $(\mathrm{J})$ & 0.0000002 & kilowatthour (kWh) \\
\hline kilojoule (kJ) & 0.0002 & kilowatthour (kWh) \\
\hline \multicolumn{3}{|c|}{ Diffusion rate } \\
\hline millimeter per hour $(\mathrm{mm} / \mathrm{hr})$ & 0.03937 & inch per hour (in/hr) \\
\hline \multicolumn{3}{|c|}{ Diffusion coefficient } \\
\hline centimeter squared per second $\left(\mathrm{cm}^{2} / \mathrm{s}\right)$ & 0.1550 & inch squared per second $\left(\mathrm{in}^{2} / \mathrm{s}\right)$ \\
\hline meter squared per second $\left(\mathrm{m}^{2} / \mathrm{s}\right)$ & 10.76 & foot squared per second $\left(\mathrm{ft}^{2} / \mathrm{s}\right)$ \\
\hline
\end{tabular}

Temperature in degrees Celsius $\left({ }^{\circ} \mathrm{C}\right)$ may be converted to degrees Fahrenheit $\left({ }^{\circ} \mathrm{F}\right)$ as follows:

$$
{ }^{\circ} \mathrm{F}=\left(1.8 \mathrm{x}^{\circ} \mathrm{C}\right)+32
$$

Temperature in degrees Fahrenheit $\left({ }^{\circ} \mathrm{F}\right)$ may be converted to degrees Celsius $\left({ }^{\circ} \mathrm{C}\right)$ as follows:

$$
{ }^{\circ} \mathrm{C}=\left({ }^{\circ} \mathrm{F}-32\right) / 1.8
$$

Concentrations of chemical constituents in water are given either in milligrams per liter (mg/L) or micrograms per liter $(\mu \mathrm{g} / \mathrm{L})$. 


\section{Acronyms}

ANAMMOX anaerobic ammonia oxidation

AOM anaerobic oxidation of methane

APPZ Avon Park permeable zone

ASR aquifer storage and recovery

ATP adenosine triphosphate

BGE bacterial growth efficiency

CERP Comprehensive Everglades Restoration Plan

CFU colony forming unit

DIC dissolved inorganic carbon

DNA deoxyribonucleic acid

DOC dissolved organic carbon

DPM disintegrations per minute

EC Escherichia coli

EPA Environmental Protection Agency

FDEP Florida Department of Environmental Protection

FEF free energy flux

fg femtogram

FI fluorescence index

FIB fecal indicator bacteria

HPOA hydrophobic organic acid

MAR maximum acquisition rate

$\lambda \quad$ wavelength

$\mu \mathrm{g} \quad$ microgram

$\mu \mathrm{L} \quad$ microliter

$\mu \mathrm{M} \quad$ micromolar

$\mathrm{mL} \quad$ milliliter

$\mathrm{mM} \quad$ millimolar

$\mathrm{mV} \quad$ millivolt

mol mole
NCBI National Center for Biotechnology Information

nM nanomolar

NMR nuclear magnetic resonance

ORP oxidation/reduction potential

OTU operational taxonomic unit

PA Pseudomonas aeruginosa

PBS phosphate buffered saline

PCA principal component analyses

PCR polymerase chain reaction

PIA Pseudomonas isolation agar

PTFE polytetrafluoroethylene

RASA Regional Aquifer-System Analysis

RMSE root mean sum of squared error

rpm revolutions per minute

rRNA ribosomal ribonucleic acid

SAGMEG South Africa Gold Mine Euarchaeotic Group

SUVA specific ultraviolet absorbance

TCA trichloroacetic acid

TDS total dissolved solids

TEAP terminal electron acceptor process

TOC total organic carbon

TPIA transphilic organic acid

UFA Upper Floridan aquifer

UIC Underground Injection Control

USDW Underground Sources of Drinking Water

USGS U.S. Geological Survey

UV ultraviolet

VFA volatile fatty acid 


\section{Acknowledgments}

The author acknowledges South Florida Water Management District (Robert Verrastro) and the U.S. Geological Survey (USGS) Water Resources Cooperative Water Program (Robert Renken) for funding support; Montana State University and Dr. Gordon McFeters for permission to modify and use their diffusion chamber design; Dr. Christina Kellogg (USGS), Dr. Dale Griffin (USGS) and Dr. June Mirecki (U.S. Army Corps of Engineers) for constructive conversations and editorial comments; and Chris Reich (USGS) and Betsy Boynton (contractor) for assistance with report formatting and graphics. 


\title{
Survival of Bacterial Indicators and the Functional Diversity of Native Microbial Communities in the Floridan Aquifer System, South Florida
}

\author{
By John T. Lisle
}

\section{Executive Summary}

The Upper Floridan aquifer in the southern region of Florida is a multi-use, regional scale aquifer that is used as a potable water source and as a repository for passively recharged untreated surface waters, injected treated surface water and wastewater, industrial wastes, and greenhouse gases (for example, carbon dioxide). The presence of confined zones within the Upper Floridan aquifer that range in salinity from fresh to brackish allow regulatory agencies to permit the injection of these different types of product waters into specific zones without detrimental effects to humans and terrestrial and aquatic ecosystems. The type of recharge that has received the most regulatory attention in south Florida is aquifer storage and recovery (ASR). The treated water, prior to injection and during recovery, must meet primary and secondary drinking water standards. The primary drinking water standard for the microbiological quality is total coliforms, which have been shown to be difficult to inactivate below the regulatory standard during the treatment process at some ASR facilities. The inefficient inactivation of this group of indicator bacteria permits their direct injection into the storage zones of the Upper Floridan aquifer. Prior to this study, the inactivation rates for any member of the total coliform group during exposure to native geochemical conditions in groundwater from any zone of the Floridan aquifer had not been derived.

Aboveground flowthrough mesocosm systems that maintained native groundwater geochemical conditions, except for pressure, were used to quantify the inactivation rates of two bacterial indicators during exposure to groundwater from six wells that collect water from two ASR storage zones: the Upper Floridan aquifer (UFA) and Avon Park Permeable Zone (APPZ). Each mesocosm contained eight membrane diffusion chambers filled with Escherichia coli or Pseudomonas aeruginosa. Both bacterial strains followed a biphasic inactivation model. The $E$. coli populations had slower inactivation rates in the UFA (range: $0.217-0.628$ per hour $\left(\mathrm{h}^{-1}\right)$ during the first phase of the model than when exposed to groundwater from the APPZ (range: $0.540-0.684 \mathrm{~h}^{-1}$ ). These same populations had significantly slower inactivation rates during the second phase of the model, ranging from 0.006 to $0.001 \mathrm{~h}^{-1}$ and 0.013 to $0.018 \mathrm{~h}^{-1}$ for the UFA and APPZ, respectively. Published inactivation rates of E. coli retained in membrane diffusion chambers and exposed to diverse groundwater sources range from 0.004 to $0.029 \mathrm{~h}^{-1}$. The inactivation rates for the first phase of the inactivation models for $P$. aeruginosa were not significantly different between the UFA (range: $0.144-0.770 \mathrm{~h}^{-1}$ ) and APPZ (range: $0.159-0.772 \mathrm{~h}^{-1}$ ) aquifer zones. The inactivation rates for the second phase of the model for this bacterial species were also similar between UFA (range: $\left.0.003-0.008 \mathrm{~h}^{-1}\right)$ and APPZ $\left(0.004-0.005 \mathrm{~h}^{-1}\right)$ zones, although significantly slower than the model's first phase rates. There are currently no inactivation data for $P$. aeruginosa in groundwater that is geochemically similar to that in UFA and APPZ for comparison.

Geochemical data were used to determine which dissimilatory biogeochemical reactions were most likely to proceed under the native conditions in the UFA and APPZ aquifer zones using 
thermodynamics principles to calculate free energy yields and other cell-related energetics data. The biogeochemical processes of acetotrophic and hydrogenotrophic sulfate reduction and methanogenesis and anaerobic oxidation of methane dominated in all six groundwater sites. All energetically favorable reactions proceeded at, or slightly greater than, the minimum free energy yield ( -20 kilojoules per mole, $\left(\mathrm{kJ} \mathrm{mol}^{-1}\right)$ ), which is the threshold for maintaining cell viability. The free-energy flux rates generated per bacterial cell for performing these biogeochemical reactions ranged from $-4.4 \times 10^{-19}$ to $-3.3 \times 10^{-16}$ kilojoules per cell per second $1\left(\mathrm{~kJ} \mathrm{cell}^{-1} \mathrm{~s}^{-1}\right)$. These flux rate values are similar to those recorded in deep subsurface microbial communities and are threefold to three orders of magnitude greater than the average cell maintenance energy requirement of $-1.55 \times 10^{-19} \mathrm{~kJ} \mathrm{cell}^{-1} \mathrm{~s}^{-1}$ ). The maximum acquisition rates of the limiting substrate (that is, hydrogen, acetate, methane) in each of the energetically favorable reactions by the total native bacterial communities at each sample site ranged from 1.1 to 648 micromolar per day $\left(\mu \mathrm{M} \mathrm{d}^{-1}\right)$.

A high throughput microarray platform technology, PhyloChip G3, was used to characterize the functional diversity in the native aquifer bacterial communities (bacteria and archaea). The diversity data were used to corroborate the most likely biogeochemical processes with the presence of one or more bacterial phylotypes capable of performing those processes. The bacterial diversity in the groundwater samples was dominated by members of the Pseudomonadaceae and to a lesser extent by members of Anaerolineaceae, Desulfobacteraceae, Peptostreptococcaceae, Lachnospiraceae and Ruminococcaceae families and the phylum Euryarchaeota. The physiological capabilities of members within these groups have been shown to include the biogeochemical processes of primary and secondary fermentation, acetogenesis, methanogenesis, anaerobic methane oxidation, syntrophy with methanogens, ammonification, and sulfate reduction. The functional bacterial diversity data support the likelihood of the energetically favorable biogeochemical reactions being present in this region of the Upper Floridan aquifer and provide insight into the capacity of the native bacterial communities to perform additional types of processes that would be required to sustain viability over geologic time scales.

The data from this study provide the first determination of bacterial indicator survival during exposure to native geochemical conditions of the Upper Floridan aquifer in south Florida. Additionally, the energetics and functional bacterial diversity characterizations are the first descriptions of native bacterial communities in this region of the Upper Floridan aquifer and reveal how these communities persist under such extreme conditions. Collectively, these types of data can be used to develop and refine groundwater models.

\section{Introduction}

During 2005, the most recent year for which data have been compiled, a total of $3.1 \times 10^{11}$ liters per day $\left(\mathrm{L} \mathrm{d}^{-1}\right)$ of groundwater were withdrawn in the United States and $1.6 \times 10^{10} \mathrm{~L} \mathrm{~d}^{-1}$ were withdrawn in Florida (Kenny and others, 2005). The majority of the groundwater in Florida is removed from the Floridan aquifer system, one of the most productive aquifers in the world (Miller, 1990). Although the Upper Floridan aquifer is a primary source of potable water, it is also a multi-use aquifer system because it contains isolated zones of moderate-to-high salinity. These nonpotable zones are currently targeted for passive recharge of stormwater runoff (Bradner, 1991), injection for the disposal of treated sewage and industrial wastes (Anonymous, 2012; Anonymous, 2013c), and recharge of treated surface water for aquifer storage and recovery (ASR) (Anonymous, 2013c). Additionally, the Cedar Keys Formation in the south Florida region of the Floridan aquifer system (Meyer, 1989; Reese and Alvarez-Zarikian, 
2006) has been identified as a possible carbon dioxide repository (Poiencot and Brown, 2011; Szulczewski and others, 2012).

The retention of any type of recharged water in the injection zone of a well is dependent upon the stratigraphy of the aquifer in that area, which can be highly variable in this region of the Upper Floridan aquifer (Renken and others, 2005). Describing the hydrogeologic framework of the Upper Floridan aquifer was not part of this project. The reader is directed to detailed descriptions of the Upper Floridan aquifer contained within the U.S. Geological Survey's Regional Aquifer-System Analysis (RASA) program reports (Bush and Johnston, 1988; Johnston and Bush, 1988; Krause and Randolph, 1989; Maslia and Hayes, 1988; Miller, 1986; Ryder, 1985; Sprinkle, 1989; Tibbals, 1990). The RASA report by Meyer (1989) specifically describes the hydrogeology of the Upper Floridan aquifer in south Florida where this study was performed. Additionally, the reader is directed to more detailed descriptions of the hydrogeologic framework of two zones within the Floridan aquifer system: the Upper Floridan aquifer (UFA) and Avon Park Permeable Zone (APPZ) (Reese and Richardson, 2008); these zones were sampled during this study.

Although there are several applications for aquifer recharge, ASR has received the most attention in south Florida because of its inclusion in the Comprehensive Everglades Restoration Project (CERP) (http://www.evergladesplan.org) as a source of water to augment Lake Okeechobee and maintain surface-water flow rates through the Everglades during periods of drought (U.S. Army Corps of Engineers and South Florida Water Management District, 1999). ASR has also been used successfully to supplement potable water sources (that is, surface water and groundwater) in coastal communities in south Florida. Recharge water injected into Florida ASR wells will reside in or above zones that contain potential sources of potable water (Anonymous, 2013b; Anonymous, 2013c). To protect these native and pristine potable sources from chemical, nutrient, and microbiological contamination, recharge water must meet primary and secondary drinking water standards prior to injection and during recovery (Anonymous, 2013a). Although significant changes in geochemistry have been shown to occur during storage of recharged water in this region of the Upper Floridan aquifer (Mirecki, 2006), these regulatory-related metrics provide little if any insight into the biogeochemical processes that drive these changes (for example, depletion of dissolved oxygen, reduction in oxidation-reduction potential, increase in hydrogen sulfides, reduction in phosphates, and so forth). In addition, the monitoring criterion for the microbiological quality of recharge water is total coliforms (Anonymous, 2013a). Although this group of bacteria is irrelevant to biogeochemical processes in aquifers, their fate and transport in recharge water during treatment and storage is important from a public health perspective (Anonymous, 1989).

Native bacterial communities are viable and productive inhabitants of all subsurface biospheres, including the Upper Floridan aquifer. These communities are capable of aerobic, fermentative, and anaerobic respiration, which can significantly influence the rates of mineral dissolution and (or) precipitation and the fate and transport of metals, organic substrates, and greenhouse gases within the aquifer. The byproducts of these processes can greatly alter the native geochemistry along a natural flow path and along a similar flow path within an artificially recharged or contaminated zone of an aquifer (Chapelle, 2000; Fredrickson and Balkwill, 2006). The south Florida region of the UFA and APPZ zones in the Upper Floridan aquifer are anaerobic, extremely reduced, and oligotrophic. Few biogeochemical studies have focused on these types of groundwater, and are non-existent for this region of the Upper Floridan aquifer. As the interest in injecting, and possibly recovering, different types of aqueous products into and from one or more zones of the Upper Floridan aquifer increases, the need for modeling the effects of the injectate on the aquifer's geologic matrix and changes in the geochemistry of the native and recharged water will also increase. The inclusion of the bacterial community "variable" in 
geochemical reactive transport models and geochemical interactions in microbial inactivation models will improve the predictive power of those models and their applicability to managing groundwater resources in the Upper Floridan aquifer as well as other aquifer systems.

\section{Problem Statement}

A major component of the Comprehensive Everglades Restoration Plan (CERP) involves the use of ASR wells to pump excess surface water during the summer rainy season into the Upper Floridan aquifer for recovery during drier months for stabilization of water flows through the Everglades ecosystem. The scale of this proposed use for ASR is unprecedented. Under current regulations, ASR wells are classified by the U.S. Environmental Protection Agency (EPA) as Class V Underground Injection Control (UIC) wells, and thus subject to regulation under the U.S. Safe Drinking Water Act. Development of controls on (and oversight of) Class V UIC wells, and generally other classes of UIC wells, falls primarily on State environmental protection agencies. As such, the Florida Department of Environmental Protection (FDEP) has set rules regulating ASR systems utilizing aquifer regions classified as Underground Sources of Drinking Water (USDW), which encompasses aquifers of under 10,000 milligrams per liter ( $\mathrm{mg} \mathrm{L}^{-1}$ ) TDS, including the Upper Floridan aquifer. A key component of these regulations is that ASR wells may not inject water that violates the Total Coliform Rule of the U.S. Safe Drinking Water Act, which specifies that potable water must have no total coliform bacteria per 100 milliliters (mL) (Anonymous, 1989, 2012, 2013a). Because surface water in Florida would most always violate this rule, the water used for injection in ASR systems must be disinfected prior to aquifer recharge to reduce total coliform concentrations below detection in $100 \mathrm{~mL}$ and, if the water is to be utilized for potable water, treated again after withdrawal. The need for this is to avoid introducing harmful microbial organisms possibly present in surface water, such as bacteria, protozoa, and viruses, into relatively pristine groundwater.

To date, only one study has characterized the inactivation rates of members of the total coliform group and other microbes (bacterial pathogens, Giardia sp., Cryptosporidium sp., and viruses) in the Upper Floridan aquifer (John, 2003). This study used autoclaved and oxidized groundwater from the Upper Floridan aquifer in bench top (laboratory beaker) microcosms to investigate the influence of total dissolved solids (TDS) and temperature on the inactivation rates of the microbial indicators and pathogens. The geochemical conditions in these microcosms did not mimic those in the anaerobic and extremely reduced south Florida region of the Upper Floridan aquifer. Therefore, inactivation rates of total coliforms and other microbial indicators and bacterial, encysted parasitic, and viral pathogens during exposure to native geochemical conditions in the Upper Floridan aquifer are still unknown.

\section{Project Objectives}

Determine the inactivation rates of Escherichia coli (a member of the total coliform group) and Pseudomonas aeruginosa (an opportunistic bacterial pathogen common in surface water) when exposed to native geochemical conditions in the Upper Floridan aquifer (UFA) and Avon Park Permeable Zone (APPZ) of the Floridan aquifer system. An aboveground flowthrough mesocosm system was used to maintain native geochemical conditions, except for pressure, during the exposure experiments.

Characterize the geochemistry in the UFA and APPZ in regard to the organic and inorganic carbon and inorganic substrates used by bacterial communities to drive biogeochemical reactions that generate energy for cell maintenance and growth while altering the geochemistry of these zones of the aquifer. 
Identify members of the native bacterial communities that are known to perform the types of biogeochemical reactions that the geochemical data show are thermodynamically feasible. In addition, identify members of these same communities that perform the biogeochemical reactions that would be necessary to maintain the native geochemical conditions in these aquifer zones, even though supporting geochemical data are not available.

\section{Methods}

\section{Site Descriptions}

Three well sites were selected, each being artesian and having dual production zones that accessed groundwater in the Upper Floridan aquifer (UFA) aquifer and Avon Park Permeable Zone (APPZ) of the Floridan aquifer system (table 1). All wells were placed and constructed as monitoring wells for CERP and had never been impacted by artificial or natural recharge (fig. 1).

Table 1. Sampling-site locations and well characteristics.

[fbs, feet below surface; UFA, upper Floridan aquifer; APPZ, Avon Park permeable zone]

\begin{tabular}{|c|c|c|c|c|c|c|c|c|}
\hline \multirow{2}{*}{$\begin{array}{c}\text { Well } \\
\text { designation }\end{array}$} & \multirow{2}{*}{$\begin{array}{l}\text { Station } \\
\text { name }\end{array}$} & \multirow{2}{*}{$\begin{array}{l}\text { Florida } \\
\text { county }\end{array}$} & \multicolumn{2}{|c|}{ Location } & \multirow{2}{*}{$\begin{array}{l}\text { Aquifer } \\
\text { zone }\end{array}$} & \multirow{2}{*}{$\begin{array}{c}\begin{array}{c}\text { Casing } \\
\text { diameter }\end{array} \\
\text { (inches) }\end{array}$} & \multirow{2}{*}{$\begin{array}{c}\begin{array}{c}\text { Production } \\
\text { interval }\end{array} \\
\text { (fbs) }\end{array}$} & \multirow{2}{*}{$\begin{array}{c}\text { Screen } \\
\text { type }\end{array}$} \\
\hline & & & Latitude & Longitude & & & & \\
\hline MZ1 & LAB-MZ1 & Glades & $26^{\circ} 45^{\prime} 11.42^{\prime \prime}$ & $-81^{\circ} 21^{\prime} 17.72^{\prime \prime}$ & UF & 18 & $670-837$ & Annular \\
\hline MZ3 & LAB-MZ3 & & & & APPZ & 7 & $1645-1759$ & Open \\
\hline $42 \mathrm{U}$ & HIF-42U & Highlands & $27^{\circ} 13^{\prime} 11.16^{\prime \prime}$ & $-80^{\circ} 57^{\prime} 21.98^{\prime \prime}$ & UF & 24 & $560-1040$ & Annular \\
\hline $42 \mathrm{~L}$ & HIF-42L & & & & APPZ & 14 & $1310-1540$ & Open \\
\hline $15 \mathrm{U}$ & PBF-15U & Palm Beach & $26^{\circ} 44^{\prime} 16.08^{\prime \prime}$ & $-80^{\circ} 21^{\prime} 48.68^{\prime \prime}$ & UF & 18 & $908-1144$ & Annular \\
\hline $15 \mathrm{M}$ & PBF-15M & & & & APPZ & 12 & $1400-1583$ & Annular \\
\hline
\end{tabular}

\section{Field Data Collection}

During each site visit, data were collected at the wellhead for temperature, specific conductance, dissolved oxygen, $\mathrm{pH}$, and oxidation/reduction potential (ORP) using an YSI 556 MPS system (YSI Inc., Ohio) attached to a flow cell. The flow cell was attached via polytetrafluoroethylene (PTFE) tubing to the stainless steel fitting that had been attached to the wellhead. This same system was also attached to the discharge side of the stainless steel inner chamber that retained the diffusion chambers in the aboveground mesocosm. Regardless of which source was being monitored, the YSI 556 MPS system was allowed to equilibrate to in situ conditions for at least 30 minutes prior to initiating an automatic data collection interval of 5 minutes for at least an hour.

\section{Geochemical and Nutrient Sample Collection and Analyses}

Samples were collected from each well, appropriately preserved and delivered to the TestAmerica Laboratory (Tampa, Fla.) on the day of collection. Each sample was analyzed for the constituents listed in table 2. Separate water samples from each well were collected for determination of dissolved inorganic carbon (DIC) and total alkalinity at the USGS laboratory in St. Petersburg, Fla. 


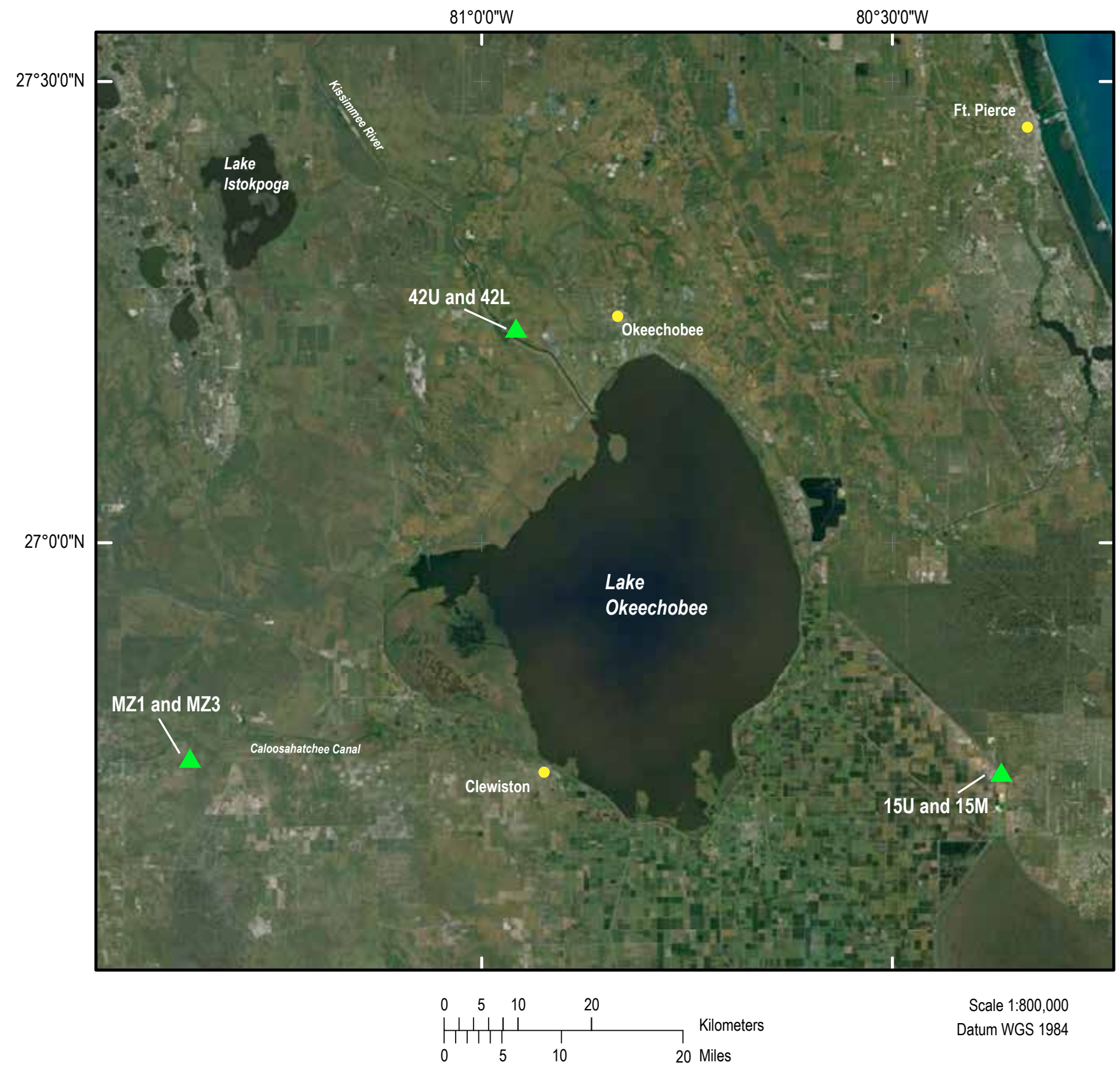

Figure 1. Aerial photograph showing sampling-site locations, indicated by green triangles.

The concentrations of bicarbonate, carbonate, and carbon dioxide were calculated using the $\mathrm{pH}$, DIC, and total alkalinity data using the software program CO2calc (Robbins and others, 2010). Data for the recharge water were provided by Dr. June Mirecki (2013). Samples for quantifying the concentrations of dissolved hydrogen $\left(\mathrm{H}_{2}\right)$ and methane $\left(\mathrm{CH}_{4}\right)$ were collected from all wells using a modified "bubble strip" system and method (Chapelle and others, 1997) as provided by Microseeps, Inc. (Pittsburg, Pa.). Stabilized dissolved-gas samples were shipped to Microseeps, Inc. for analyses. 
Table 2. Water-quality data for the six sampling sites.

[ORP, oxidation/reduction potential; ${ }^{\circ} \mathrm{C}$, degrees centigrade; $\mathrm{mS} / \mathrm{cm}$, millisiemens per centimeter; $\mathrm{g} / \mathrm{L}$, grams per liter; ppt, parts per thousand; $\mathrm{mV}$, millivolts; $\mathrm{mg} / \mathrm{L}$, milligrams per liter; $\mathrm{nM}$, nanomolar; $\mu \mathrm{M}$, micromolar; $\mathrm{BDL}$, below detection limit; ND, not determined]

\begin{tabular}{|c|c|c|c|c|c|c|c|c|}
\hline \multirow{2}{*}{ Parameter } & \multirow{2}{*}{ Units } & \multicolumn{7}{|c|}{ Well designation } \\
\hline & & MZ1 & MZ3 & $42 \mathrm{U}$ & $42 \mathrm{~L}$ & $15 U$ & $15 \mathrm{M}$ & Recharge \\
\hline Temperature & ${ }^{\circ} \mathrm{C}$ & 28.7 & 27.8 & 28.2 & 28.5 & 27.9 & 28.0 & 25.5 \\
\hline Specific conductance & $\mathrm{mS} / \mathrm{cm}$ & 3.146 & 27.98 & 1.029 & 6.044 & 5.876 & 5.009 & 0.223 \\
\hline Total dissolved solids & $g / L$ & 2.045 & 18.19 & 0.669 & 3.928 & 3.819 & 3.255 & 0.208 \\
\hline Salinity & ppt & 1.63 & 17.03 & 0.5 & 3.26 & 3.17 & 2.67 & ND \\
\hline $\mathrm{pH}$ & & 8.02 & 7.38 & 8.04 & 7.61 & 7.60 & 7.64 & 6.70 \\
\hline ORP & $\mathrm{mV}$ & -312 & -309 & -338 & -351 & -355 & -365 & 132 \\
\hline Aluminum & $\mathrm{mg} / \mathrm{L}$ & $\mathrm{BDL}$ & $\mathrm{BDL}$ & $\mathrm{BDL}$ & $\mathrm{BDL}$ & $\mathrm{BDL}$ & $\mathrm{BDL}$ & 0.091 \\
\hline Barium & $\mathrm{mg} / \mathrm{L}$ & 0.039 & 0.035 & 0.034 & 0.040 & 0.015 & 0.028 & 0.019 \\
\hline Bromine & $\mathrm{mg} / \mathrm{L}$ & 2.0 & 34.0 & $\mathrm{BDL}$ & 5.1 & 4.8 & 4.3 & 0.1 \\
\hline Calcium & $\mathrm{mg} / \mathrm{L}$ & 80 & 550 & 44 & 200 & 120 & 110 & 19 \\
\hline Chloride & $\mathrm{mg} / \mathrm{L}$ & 640 & 9700 & 160 & 1600 & 1600 & 1300 & 31 \\
\hline Chromium & $\mathrm{mg} / \mathrm{L}$ & $\mathrm{BDL}$ & $\mathrm{BDL}$ & $\mathrm{BDL}$ & $\mathrm{BDL}$ & $\mathrm{BDL}$ & $\mathrm{BDL}$ & 0.001 \\
\hline Cobalt & $\mathrm{mg} / \mathrm{L}$ & $\mathrm{BDL}$ & BDL & BDL & 0.002 & BDL & $\mathrm{BDL}$ & 0.0001 \\
\hline Copper & $\mathrm{mg} / \mathrm{L}$ & BDL & BDL & BDL & BDL & BDL & $\mathrm{BDL}$ & 0.0010 \\
\hline Fluoride & $\mathrm{mg} / \mathrm{L}$ & 0.78 & $\mathrm{BDL}$ & 0.57 & 0.29 & 0.97 & 1.10 & 0.10 \\
\hline Lead & $\mathrm{mg} / \mathrm{L}$ & BDL & $\mathrm{BDL}$ & $\mathrm{BDL}$ & BDL & $\mathrm{BDL}$ & $\mathrm{BDL}$ & 0.0003 \\
\hline Magnesium & $\mathrm{mg} / \mathrm{L}$ & 75.0 & 650.0 & 33.0 & 140.0 & 130.0 & 120.0 & 6.9 \\
\hline Nickel & $\mathrm{mg} / \mathrm{L}$ & BDL & BDL & BDL & BDL & $\mathrm{BDL}$ & BDL & 0.0007 \\
\hline Potassium & $\mathrm{mg} / \mathrm{L}$ & 24.0 & 230.0 & 5.5 & 40.0 & 36.0 & 29.0 & 4.0 \\
\hline Selenium & $\mathrm{mg} / \mathrm{L}$ & $\mathrm{BDL}$ & $\mathrm{BDL}$ & $\mathrm{BDL}$ & $\mathrm{BDL}$ & $\mathrm{BDL}$ & $\mathrm{BDL}$ & 0.0009 \\
\hline Silica & $\mathrm{mg} / \mathrm{L}$ & 9.8 & 9.1 & 14.0 & 12.0 & 13.0 & 13.0 & 1.2 \\
\hline Sodium & $\mathrm{mg} / \mathrm{L}$ & 440 & 4700 & 98 & 800 & 890 & 740 & 16 \\
\hline Zinc & $\mathrm{mg} / \mathrm{L}$ & BDL & $\mathrm{BDL}$ & $\mathrm{BDL}$ & $\mathrm{BDL}$ & $\mathrm{BDL}$ & $\mathrm{BDL}$ & 0.0447 \\
\hline Dissolved oxygen & $\mathrm{mg} / \mathrm{L}$ & 0 & 0 & 0 & 0 & 0 & 0 & 4.4 \\
\hline Manganese & $\mathrm{mg} / \mathrm{L}$ & 0.013 & 0.035 & 0.007 & 0.006 & 0.011 & 0.010 & 0.005 \\
\hline Ferric iron & $\mathrm{mg} / \mathrm{L}$ & 0.14 & 0.19 & 0.10 & 0.17 & 0.28 & 0.38 & ND \\
\hline Ferrous iron & $\mathrm{mg} / \mathrm{L}$ & 0.03 & 0.03 & 0.03 & 0.03 & 0.06 & 0.02 & ND \\
\hline Iron (total) & $\mathrm{mg} / \mathrm{L}$ & 0.17 & 0.22 & 0.12 & 0.20 & 0.34 & 0.40 & 0.26 \\
\hline Ammonium & $\mathrm{mg} / \mathrm{L}$ & 0.19 & 0.28 & 0.20 & 0.26 & 0.44 & 0.33 & 0.09 \\
\hline Nitrate & $\mathrm{mg} / \mathrm{L}$ & BDL & $\mathrm{BDL}$ & $\mathrm{BDL}$ & $\mathrm{BDL}$ & BDL & $\mathrm{BDL}$ & 0.15 \\
\hline Nitrite & $\mathrm{mg} / \mathrm{L}$ & BDL & $\mathrm{BDL}$ & $\mathrm{BDL}$ & $\mathrm{BDL}$ & $\mathrm{BDL}$ & $\mathrm{BDL}$ & 0.016 \\
\hline Kjeldahl Nitrogen & $\mathrm{mg} / \mathrm{L}$ & 0.25 & 0.38 & 0.21 & 0.29 & 0.52 & 0.53 & 1.10 \\
\hline Sulfate & $\mathrm{mg} / \mathrm{L}$ & 380 & 1800 & 180 & 510 & 450 & 370 & 16 \\
\hline Sulfide & $\mathrm{mg} / \mathrm{L}$ & 2.1 & 1.6 & 1.4 & 1.6 & 3.7 & 4.2 & $\mathrm{BDL}$ \\
\hline Phosphate & $\mathrm{mg} / \mathrm{L}$ & BDL & $\mathrm{BDL}$ & $\mathrm{BDL}$ & $\mathrm{BDL}$ & $\mathrm{BDL}$ & BDL & 0.067 \\
\hline Dissolved organic carbon & $\mathrm{mg} / \mathrm{L}$ & 1.2 & 1.1 & 1.1 & 1.2 & 1.7 & 1.9 & 15.7 \\
\hline Acetic acid & $\mathrm{mg} / \mathrm{L}$ & 0.120 & 0.070 & 0.095 & 0.070 & 0.120 & 0.070 & ND \\
\hline Lactic acid & $\mathrm{mg} / \mathrm{L}$ & BDL & 3.8 & $\mathrm{BDL}$ & $\mathrm{BDL}$ & $\mathrm{BDL}$ & BDL & ND \\
\hline Propionic acid & $\mathrm{mg} / \mathrm{L}$ & 0.071 & $\mathrm{BDL}$ & BDL & $\mathrm{BDL}$ & $\mathrm{BDL}$ & 0.190 & ND \\
\hline Pyruvic acid & $\mathrm{mg} / \mathrm{L}$ & 0.067 & BDL & BDL & $\mathrm{BDL}$ & $\mathrm{BDL}$ & $\mathrm{BDL}$ & ND \\
\hline Total inorganic carbon & $\mathrm{mg} / \mathrm{L}$ & 160 & 200 & 210 & 190 & 310 & 330 & ND \\
\hline Bicarbonate & $\mathrm{mg} / \mathrm{L}$ & 151.5 & 190.0 & 199.1 & 181.7 & 296.4 & 315.8 & ND \\
\hline Carbonate & $\mathrm{mg} / \mathrm{L}$ & 6.8 & 4.2 & 8.8 & 3.4 & 5.3 & 6.0 & ND \\
\hline
\end{tabular}


Table 2. Water-quality data for the six sampling sites.- Continued.

[ORP, oxidation/reduction potential; ${ }^{\circ} \mathrm{C}$, degrees centigrade; $\mathrm{mS} / \mathrm{cm}$, millisiemens per centimeter; $\mathrm{g} / \mathrm{L}$, grams per liter; ppt, parts per thousand; $\mathrm{mV}$, millivolts; $\mathrm{mg} / \mathrm{L}$, milligrams per liter; $\mathrm{nM}$, nanomolar; $\mu \mathrm{M}$, micromolar; BDL, below detection limit; ND, not determined]

\begin{tabular}{lcccccccc}
\hline \multirow{2}{*}{ Parameter } & \multirow{2}{*}{ Units } & \multicolumn{9}{c}{ Well designation } \\
\cline { 3 - 9 } & & MZ1 & MZ3 & 42U & 42L & 15U & 15M & Recharge \\
\hline Carbon dioxide & $\mathrm{mg} / \mathrm{L}$ & 1.7 & 5.9 & 2.2 & 4.9 & 8.3 & 8.2 & ND \\
Hydrogen & $\mathrm{nM}$ & 120.0 & 1.2 & 95.0 & 6.4 & 62.0 & 35.0 & ND \\
Methane & $\mu \mathrm{M}$ & 2.00 & 0.94 & 0.69 & 0.54 & 1.00 & 1.06 & $\mathrm{ND}$ \\
\hline
\end{tabular}

\section{Statistical Analyses}

The geochemical data from the respective wells were analyzed using the multivariate statistical procedure for principal component analyses (PCA) on a derived correlation matrix. The oxidation/ reduction potential (ORP) data for all wells were negative because of the reduced conditions. Prior to the data processing, these were changed to positive values to allow data transformation. All data were $\log 10$-transformed, normalized, and used to derive a correlation matrix on which the PCA was performed. These data were used to determine relative similarities between each well site and each depth within a well site. All statistical analyses were conducted using PRIMER 6 (version 6.1.12; PRIMER-E, Ltd., Plymouth, U.K.).

\section{Native Bacterial Abundances}

Samples $(50 \mathrm{~mL})$ were collected from each well and immediately preserved with filter-sterilized formalin at a final concentration of 3.0 percent. The samples were placed in an container and kept in the dark during transport. Upon return to the USGS laboratory in St. Petersburg, Fla., samples were stored at $4{ }^{\circ} \mathrm{C}$. Samples were filtered and stained using SYBR Gold (Molecular Probes, Inc.), as previously described for the enumeration of bacteria (Lisle and Priscu, 2004). All bacteria on the prepared slides were counted using an epifluorescent microscope equipped with a filter cube set specifically designed to optimize the visualization of the SYBR Gold stain.

\section{Aboveground Mesocosms}

The diffusion chambers used in this study are an alternative design of the McFeters diffusion chamber (McFeters and others, 1974; McFeters and Stuart, 1972; McFeters and Terzieva, 1991; Terzieva and McFeters, 1991; Zaske and others, 1980). A series of diffusion chambers were used to retain the previously described bacterial suspensions, using 0.02 -micrometer $(\mu \mathrm{m})$-pore-size membranes (Lisle, 2005). The membrane physically isolates the E. coli and P. aeruginosa cells from predation by native bacteria, while allowing the diffusion of dissolved groundwater constituents into and from the chambers.

The diffusion chambers, when constructed, measure $(\mathrm{w} \times 1 \times \mathrm{d}) 4.0 \times 12.0 \times 2.3$ centimeters $(\mathrm{cm})$ with an internal volume of approximately $15.0 \mathrm{~mL}$ (appendix 1). Because of wellhead access constraints and the multiple time point sampling design of the experiments, down-well deployments of the diffusion chambers were not practical. An aboveground mesocosm system was designed that allowed easy access to the diffusion chambers while insulating the chambers from the elevated surface temperatures and minimizing alterations in the geochemistry of the native groundwater (appendix 1).

The mesocosm system is a two chamber system; the outermost chamber is a commercial icecooler adapted to connect directly to the wellhead via PTFE tubing on one end with a $5.0 \times 15.0-\mathrm{cm}$ discharge opening on the other to allow high flow rates through the chamber (appendix 1). The PTFE tubing leading from the wellhead has a valve system connected that allows the diversion of water through a flow-regulating valve and then through the side of the chamber. The second chamber is stainless 
steel $(45.1 \times 20.3 \times 17.8 \mathrm{~cm})$, sits inside the outer chamber, and has an internal volume of approximately 16.0 liters (L). The inner chamber is baffled with vertical stainless steel inserts that ensure laminar and plug flow, while allowing the placement of diffusion chambers between the baffles. The lid of the inner chamber is made of a nontoxic polymer that has been engineered to receive threaded plugs made of the same material, preventing water outside of this chamber from entering. These plugs have attachment points on their undersides for hanging diffusion chambers that contain the bacterial suspensions. There are eight plugs per stainless steel chamber. The PTFE tubing leading from the flow regulating valve is attached to one end of the outer chamber. A discharge PTFE tube is connected to the down-flow end of this chamber and run to the outside the outermost chamber (that is, the cooler). Flow through the outer most chamber (approximately 10.0 liters per minute $\left.\left(\mathrm{L} \mathrm{min}^{-1}\right)\right)$ is maintained at high enough rates that the water insulates from temperature and isolates from oxygen the water and diffusion chambers that contain the bacterial suspensions inside the stainless steel chamber. The flow rate inside the stainless steel chamber was maintained at approximately 152 milliliters per minute $\left(\mathrm{mL} \mathrm{min}^{-1}\right)$ for all of the wells. This flow rate provides a linear flow velocity of approximately 6.0 meters per day $\left(\mathrm{m} \mathrm{d}^{-1}\right)$ with a residence time of approximately 2.0 hours. Therefore, the flow rate through the outermost chamber is approximately 64 times greater than that inside the stainless steel chamber. The ambient air and groundwater temperatures at the wellhead and in the outer and inner chambers were monitored throughout each experiment using HOBO Pro v2 temperature loggers (Onset Computer Corp., Inc., Pocasset, Mass.).

\section{Bacterial Cultures}

Treated surface water that will be injected into aquifers is regulated for chemical and microbiological quality as per the Safe Drinking Water Act; therefore, fecal indicator bacteria (FIB) in the treated water is a regulatory concern. However, data on the in situ inactivation and survival of FIB in the Upper Floridan aquifer are not available. To model the inactivation of FIB in the region of the Upper Floridan aquifer that underlies south Florida, two representative bacterial strains were selected from a commercial source. An E. coli (ATCC \#BAA-1159) (EC) and P. aeruginosa (ATCC\#29260) (PA) strain were selected that had been originally isolated from freshwater sources. The EC strain is the most recognizable member of the FIB group and the PA strain was selected because it is an emerging opportunistic pathogen of public health concern in recreational waters.

Both bacterial strains were grown, processed, and used to load the diffusion chambers as follows. A 5.0-mL primary culture of the EC and PA strains were grown in Tryptic Soy Broth (\#211824; BD Diagnostics, Md.) and Nutrient Broth (\#233000; BD Diagnostics, Md.), respectively, at $37{ }^{\circ} \mathrm{C}$ with gently rotational shaking $(160 \mathrm{rpm})$ overnight. A 100 -microliter $(\mu \mathrm{L})$ sample of each primary culture was used to inoculate a secondary $5.0-\mathrm{mL}$ culture of the same media and grown under the same conditions. The next day, $1.0 \mathrm{~mL}$ of each culture was used to inoculate a $150-\mathrm{mL}$ culture of the same media and again grown overnight under the same conditions. Between 20 and $25 \mathrm{~mL}$ of each of these overnight cultures were centrifuged for 5 minutes at $10,000 \times \mathrm{g}$ and $4{ }^{\circ} \mathrm{C}$. The resulting pellets were resuspended in $20 \mathrm{~mL}$ of phosphate buffered saline (PBS) (137.0 millimolar $(\mathrm{mM}) \mathrm{NaCl} ; 2.7 \mathrm{mM} \mathrm{KCl} ; 11.9 \mathrm{mM} \mathrm{PO}$; $\mathrm{pH}$ 7.3-7.5) and centrifuged again using the same parameters. The resulting pellet from this step was then adjusted to a spectrophotometric absorbance value $(\lambda=420$ nanometers $(\mathrm{nm}))$ using PBS that represented a cell concentration of $5 \times 10^{9}$ cells $\mathrm{mL}^{-1}$ based on a laboratory-generated standard curve. These adjusted cell suspensions were placed in a cooler with coolant and transported to the well site. The travel time ranged from 1.5 to 3.0 hours.

At the well site, 1.0 L of the native groundwater was collected in sterile bottles and filter steril-

ized. Two 198-mL volumes were transferred to separate flasks, one for EC and the other for PA, and 
$2.0 \mathrm{~mL}$ of the respective concentrated cell suspensions were added. These final bacterial suspensions were gently mixed, and $15.0 \mathrm{~mL}$ of each were transferred by syringe to fill a separate diffusion chamber for each strain, giving an estimated cell concentration of $5 \times 10^{8}$ to $1 \times 10^{9}$ cells per chamber (approximately $3-7 \times 10^{7}$ cells $\mathrm{mL}^{-1}$ ). This process was repeated for a total of eight diffusion chambers per strain. Each loaded diffusion chamber was immediately transferred to the stainless steel inner chamber, which was filled with native groundwater, sealed, and submerged in the native groundwater flowing through the outer chamber of the aboveground mesocosm.

At each sampling time point, the groundwater flow into the outer chamber of the aboveground mesocosm was diverted to waste and the remaining water in the outer chamber drained until it was below the top of the inner chamber, which contained the diffusion chambers. One EC and one PA diffusion chamber were removed and immediately transferred to a container filled with native groundwater that was placed in a cooler and stored in the dark. The inner chamber was then resealed, groundwater flow into the aboveground mesocosm system was restarted, and the diffusion chambers were taken to the field laboratory. Once in the laboratory, the water in each chamber was extracted using a syringe and transferred to sterile tubes; the extracted volume was serially diluted with PBS. Selected dilutions were filtered through membrane filters (47-millimeter $(\mathrm{mm})$ diameter, $0.45-\mu \mathrm{m}$ pore size) and placed on modified mTEC agar (BD Diagnostics, Md.; \#214884), hereafter referred to as mTEC agar, for EC and incubated at $35^{\circ} \mathrm{C}$ for 2 hours and then transferred to a $44.5^{\circ} \mathrm{C}$ incubator for an additional 22 to 24 hours. mTEC agar was included because this medium is one of the required media listed in the U.S. EPA regulations for the recovery of EC from water samples (U.S. Environmental Protection Agency, 2002).

The membrane filters inoculated with PA were placed on Pseudomonas Isolation Agar (BD Diagnostics, Md.; \#292710) and incubated at 35.0 ${ }^{\circ} \mathrm{C}$ for 18 to 48 hours. At the end of the respective incubation periods, all filters were counted for the number of colony forming units (CFU) per filter based on the diagnostic colony characteristics (Zimbro and others, 2009). All data were normalized to volumes plated and expressed as $\mathrm{CFU} \mathrm{mL}^{-1}$

In addition to the strain specific media, a select set of the dilutions for both strains were also plated on R2A agar (BD Diagnostics, Md.; \#218263) using a modified drop plate technique (Hoben and Somasegaran, 1982). These samples were incubated at room temperature in the dark for as many days as it took for the CFU values to stabilize, namely between 10 and 14 days. All data were normalized to volumes plated and expressed as CFU mL $\mathrm{mL}^{-1}$ The concentrations of EC and PA in the native groundwater were also quantified using the same media, dilution scheme, and respective incubation conditions as described previously.

\section{Inactivation Data Analyses}

The CFU mL $\mathrm{mL}^{-1}$ data for EC and PA on $\mathrm{mTEC}$ and PA agars, respectively, and R2A agar were used to model the inactivation rates in native groundwater from each well, as measured by the loss of culturability on the respective media over time. The best-fit inactivation model was selected by analyzing each dataset with a suite of six equations that have been shown to represent the most common inactivation data distributions for bacteria based on culturability (Crane and Moore, 1986; Xiong and others, 1999).

\section{Quantification and Characterization of Dissolved Organic Carbon (DOC)}

Routine monitoring of groundwater systems includes quantification of total organic carbon (TOC). Although of general interest from an operational perspective, this parameter provides little 
insight into how carbon is utilized by the microbial populations in groundwater systems. The percentage of TOC that is assimilable for microbial populations is typically very small, making this parameter relatively insensitive when trying to assess microbial processes. The dissolved organic carbon (DOC) component of TOC has been shown in all ecosystems studies to be the preferred source of carbon for microbial populations. Not all DOC is available for microbial assimilation, however, so an understanding of which DOC constituents are bioavailable is of interest. In addition, the source of the DOC in this region of the Upper Floridan aquifer is of interest because it is assumed that photosynthetically fixed carbon has not been introduced into this groundwater since it was recharged into the subsurface over 20,000 years before present (Meyer, 1989; Plummer and Sprinkle, 2001).

Groundwater samples $(3.0 \mathrm{~L})$ were collected in sterile bottles from each well, packed in coolers, and shipped overnight to the USGS National Research Program laboratory in Boulder, Colo. The samples were processed upon receipt by passing the water through a series of XAD resin columns as previously described for the separate isolation and elution of hydrophobic organic acid (HPOA) and transphilic organic acid (TPIA) fractions of the total DOC (Aiken and others, 1992; Aiken, 1992). The different eluted samples were characterized by elemental, molecular-weight titration and ${ }^{13} \mathrm{C}-\mathrm{NMR}$ analyses. The specific UV absorbance (SUVA) was also determined for each eluted fraction at a wavelength of $254 \mathrm{~nm}$ (Weishaar and others, 2003).

The analysis just described was used to estimate the quantity of dissolved aromatic carbon constituents in the water samples. In addition, the fluorescence index (FI) was determined for the total and eluted fractions of the DOC (McKnight and others, 2001). The FI provides information about the source (terrestrial versus microbial) of fluorescing organic matter in the samples. FI values are normally in the range of 1.0 to 2.0, with values of 1.0 to 1.3 indicating the DOC is from a terrestrial source and 1.7 to 2.0 indicating microbial source. FI values of 1.4 to 1.6 indicate mixtures of DOC that originate from terrestrial and microbial sources.

\section{Volatile Fatty Acid (VFA) Data Collection}

Volatile fatty acids are short carbon-chain compounds that are byproducts of, and nutrient sources for, bacterial communities in groundwater systems. Samples were collected (100 mL) from each well, preserved and packaged per the analyzing laboratory's instructions, and shipped overnight to Microseeps, Inc. (Pittsburg, Pa.). This additional analysis was necessary because one of the VFAs, namely acetic acid $\left(\mathrm{CH}_{3} \mathrm{COO}^{-}\right)$or acetate $\left(\mathrm{CH}_{3} \mathrm{COOH}\right)$, was used as the substrate to determine bacterial community respiration rates. For the derived respiration rate data to be meaningful, the concentration of acetate added to the assay must be significantly lower than the native concentration (Wright and Burnison, 1979). In addition, the presence and relative concentrations of VFAs provide insight into the microbial biogeochemical processes (for example, fermentation, acetogenesis, and sulfate reduction) that most likely dominate in these aquifer systems.

\section{Bacterial Respiration and Carbon Turnover and Carbon Dioxide Production Rates}

Respiratory rates of the native bacterial populations were determined using radiolabelled substrates, which are appropriate for the geochemical conditions in aquifers (Hobbie, 1973; Wright, 1978; Wright and Hobbie, 1966). ${ }^{14} \mathrm{C}$-labeled acetate was the choice for these groundwater systems because this volatile fatty acid is naturally present and assumed to be a carbon source the native bacterial populations could utilize. All sample processing in the field and laboratory was performed under a constant stream of nitrogen gas to ensure the in situ anaerobic conditions were maintained. Prior to the collection of the 
groundwater samples, the appropriate volume of ${ }^{14} \mathrm{C}$-acetate was added to sterile flasks to achieve a final concentration in the sample of 20 nanomolar $(\mathrm{nM})$ and left open under continuous nitrogen gas flow until the ethanol carrier had evaporated. This step ensured a second and nonradiolabelled carbon substrate (that is, ethanol) was not available for assimilation by the microbial communities, thereby confounding the growth-rate measurements based on radiolabelled acetate. A 70-mL sample from each well was added to pre-dosed flasks, and gently mixed; after which $5.0 \mathrm{~mL}$ subsamples were transferred to separate $25-\mathrm{mL}$ serum bottles that were immediately sealed with butyl rubber stoppers. The biological activity in the time-zero replicate set of bottles was immediately inactivated by adding 500 microliters $(\mu \mathrm{L})$ of $4 \mathrm{~N} \mathrm{H}_{2} \mathrm{SO}_{4}$. After adding the acid, each bottle was gently shaken on a rotary shaker between 8-16 hours. The remaining samples were returned to the laboratory and placed in an anaerobic chamber that had been flushed and filled with nitrogen gas for continued incubation at room temperature in the dark.

For the time-zero samples and those for all other time points, both bottles of the replicate set were processed for the recovery of ${ }^{14} \mathrm{CO}_{2}$ and ${ }^{14} \mathrm{C}$-labelled bacterial biomass. Each sample bottle was connected to $\mathrm{a} \mathrm{CO}_{2}$ scrubbing system that consisted of three airtight vials, the last two of which contained $4.0 \mathrm{~mL}$ of Carbo-Sorb ETM (PerkinElmer, Waltham, Mass.). The sample was inactivated, as described previously, and gently shaken for 5 minutes. A nitrogen gas source was then attached and used to gently flush the head space of the sample and scrubbing bottles for 5 minutes. The two bottles containing the Carbo-Sorb E were removed and $5.0 \mathrm{~mL}$ of Permafluor E E $^{+\mathbf{T M}}$ (PerkinElmer, Waltham, Mass.) added. The acidified sample in each bottle, which contains the bacterial biomass, was filtered through a 25 -mm-diameter 0.20 - $\mu \mathrm{m}$-pore-size filter. The filters were then rinsed three times with sterile water, briefly dried, and placed in a scintillation vial to which $5.0 \mathrm{~mL}$ of Permafluor $\mathrm{E}^{+}$was added. All scintillation vials were allowed to set overnight at room temperature to quench, and then read the next day in a scintillation counter to record disintegrations per minute (DPM). The DPM data from the two bottles of Carbo-Sorb E per sample were added to give a single value that was used to calculate the mean DPM at each time point. Each set of mean DPM per unit time data were used in all respiration and productivity calculations.

The DPM per unit time data were used to calculate the acetate turnover rates using the following relationship (Wright and Burnison, 1979):

$$
T_{n}=\frac{S_{n}+A}{v_{n}}=\frac{t}{f},
$$

where

$T_{n} \quad$ is the turnover rate for, in this case, acetate;

$S_{n} \quad$ is the natural concentration of acetate in the groundwater;

$A \quad$ is the concentration of radiolabeled acetate added to each experiment;

$t \quad$ is the time of each experiment;

$f \quad$ is the decimal fraction of total radiolabelled acetate utilized by the microbial community during the experiment; and

$v_{n} \quad$ is the acetate utilization rate by the native microbial communities.

The rates of community respiration and production $\left(v_{n}\right)$ were the slopes of the mean DPM per unit time data in the linear portion of each dataset and subsequently analyzed using model I linear regression. 
Bacterial community biomass turnover rates can also be estimated from the incorporation rates of an amino acid, leucine, into cellular proteins (Bastviken and Tranvik, 2001; Buesing and Marxsen, 2005; Phelps and others, 1994; Simon and Azam, 1989). Accordingly, tritium-labeled leucine $\left({ }^{3} \mathrm{H}\right.$-leucine) was added to the native groundwater from the six wells following the method of Kirchman (2001). Briefly, ${ }^{3} \mathrm{H}$-leucine was added to $35 \mathrm{~mL}$ of the respective groundwater sources to achieve a final concentration of $20 \mathrm{nM}$ leucine, gently mixed, then followed by the transfer of $1.7 \mathrm{~mL}$ of the suspension to multiple $2.0-\mathrm{mL}$ screw-cap vials under a continuous flow of nitrogen gas. A set of three vials representing the time-zero samples were immediately inactivated with the addition of $89 \mu \mathrm{L}$ of ice-cold trichloroacetic acid (TCA) and gently mixed. The vials were centrifuged at approximately $16,000 \times \mathrm{g}$ for 10 minutes at room temperature and the supernatant aspirated. A 1.0-mL volume of ice-cold 5.0-percent (v/v) TCA was added to each vial, gently mixed, and centrifuged as before. The supernatant was again aspirated and $1.0 \mathrm{~mL}$ of ice-cold 80 -percent (v/v) ethanol was added, gently mixed, and centrifuged as described. The supernatant was aspirated and the remaining pellet air-dried to remove residual ethanol. To each dried pellet, $1.0 \mathrm{~mL}$ of Ultima Gold ${ }^{\mathrm{TM}}$ (PerkinElmer, Mass.) scintillation fluid was added, gently mixed, and allowed to sit at room temperature overnight. The remaining sample vials were transferred to an activated GasPak ${ }^{\mathrm{TM}}$ (BD Diagnostics, N.J.) for transportation back to the laboratory where the vials were transferred to an anaerobic chamber for incubation at room temperature in the dark. At each time point, three vials from each groundwater source were inactivated and processed as described previously. All processed samples were analyzed in a scintillation counter to record the DPM.

The equation used for relating leucine incorporation rates to bacterial biomass production (Kirchman, 1993; Kirchman and Ducklow, 1993) ( $B P_{\text {leu }}$; grams carbon per liter per hour) is

$$
B P_{l e u}=\operatorname{Leu}_{i} \cdot M W_{l e u} \cdot \operatorname{Leu}_{f}^{-1} \cdot C P R \cdot D_{i}
$$

where

$M W_{\text {leu }}$ is the formula weight of leucine (131.2 grams per mole $\left.\left(\mathrm{g} \mathrm{mol}^{-1}\right)\right)$;

$\mathrm{Leu}_{f} \quad$ is the fraction of leucine in bacterial proteins $(0.073)$;

$C P R \quad$ is the cellular carbon-to-protein ratio in bacteria (0.86);

$D_{i} \quad$ is the isotope dilution factor (2); and

$\mathrm{Leu}_{i} \quad$ is the leucine incorporation rate (moles leucine per liter per hour), which was determined from linear portion of the scintillation count (DPM) per unit time regression data as described for the ${ }^{14} \mathrm{C}$-acetate experiments.

The acetate mineralization and leucine assimilation rates were used to calculate the quantity of bacterial biomass produced per unit of organic carbon substrate assimilated as expressed by bacterial growth efficiencies $(B G E)$ (del Giorgio and Cole, 1998). The $B G E$ for the respective native microbial communities is estimated from the following equation:

$$
B G E=B P /(B P+B R),
$$

where

$B P \quad$ is the microbial community production rate (that is, ${ }^{3} \mathrm{H}$-leucine data for biomass production expressed as micrograms carbon per hour); and

$B R$ is the microbial community respiration rate (that is, $\mathrm{CO}_{2}$ production from ${ }^{14} \mathrm{C}$-acetate expressed as micrograms carbon per hour). 


\section{Biogeochemical and Energetics Analyses}

Data for the biogeochemical analyses were selected from those groundwater constituents in table 2 that were above the respective detection limits. Based on the geochemical data that provided a complete set of reactants and products for the respective reactions, a set of 14 biogeochemical reactions were selected that are commonly known to be driven by bacteria in groundwater systems (Davidson and others, 2011; Onstott, 2005) (table 3).

Table 3. Balanced biogeochemical reactions.

\begin{tabular}{cl}
\hline Reaction number & \multicolumn{1}{c}{ Reaction equations } \\
\hline 1 & $4 \mathrm{H}_{2}+\mathrm{H}^{+}+\mathrm{SO}_{4}^{2-} \rightarrow \mathrm{HS}^{-}+4 \mathrm{H}_{2} \mathrm{O}$ \\
2 & $\mathrm{CH}_{3} \mathrm{COO}^{-}+\mathrm{SO}_{4}^{2-} \rightarrow 2 \mathrm{HCO}_{3}^{-}+\mathrm{HS}^{-}$ \\
3 & $4 \mathrm{H}_{2}+\mathrm{H}^{+}+\mathrm{HCO}_{3}^{-} \rightarrow \mathrm{CH}_{4}+3 \mathrm{H}_{2} \mathrm{O}$ \\
4 & $\mathrm{CH}_{3} \mathrm{COO}^{-}+\mathrm{H}_{2} \mathrm{O} \rightarrow \mathrm{CH}_{4}+\mathrm{HCO}_{3}^{-}$ \\
5 & $4 \mathrm{HCOO}^{-}+\mathrm{H}^{+}+\mathrm{H}_{2} \mathrm{O} \rightarrow \mathrm{CH}_{4}+3 \mathrm{HCO}_{3}^{-}$ \\
6 & $4 \mathrm{H}_{2}+\mathrm{H}^{+}+2 \mathrm{HCO}_{3}^{-} \rightarrow \mathrm{CH}_{3} \mathrm{COOH}_{4}+4 \mathrm{H}_{2} \mathrm{O}$ \\
7 & $2 \mathrm{CO}_{2}+4 \mathrm{H}_{2} \rightarrow \mathrm{CH}_{3} \mathrm{COOH}^{-2} \mathrm{H}_{2} \mathrm{O}$ \\
10 & $\mathrm{HS}^{-}+\mathrm{NO}_{3}^{-}+\mathrm{H}_{2} \mathrm{O}^{-} \mathrm{SO}_{4}^{2-}+\mathrm{NH}_{3}$ \\
12 & $\mathrm{CH}_{4}+\mathrm{SO}_{4}^{2-} \rightarrow \mathrm{H}_{2} \mathrm{O}^{2}+\mathrm{HCO}_{3}^{-}+\mathrm{HS}^{-}$ \\
17 & $\mathrm{H}_{2} \mathrm{~S}+4 \mathrm{NO}_{3}^{-} \rightarrow \mathrm{SO}_{4}^{2-}+4 \mathrm{NO}_{2}^{-}+2 \mathrm{H}^{+}$ \\
19 & $3 \mathrm{H}_{2} \mathrm{~S}^{-}+4 \mathrm{NO}_{2}^{-}+2 \mathrm{H}^{+}+4 \mathrm{H}_{2} \mathrm{O} \rightarrow 3 \mathrm{SO}_{4}^{2-}+4 \mathrm{NH}_{4}^{+}$ \\
25 & $\mathrm{NH}_{3}+1.5 \mathrm{O}_{2} \rightarrow \mathrm{NO}_{2}^{-}+\mathrm{H}^{+}+\mathrm{H}_{2} \mathrm{O}$ \\
26 & $2 \mathrm{NO}_{2}^{-}+\mathrm{O}_{2} \rightarrow 2 \mathrm{NO}_{3}^{-}$ \\
27 & $\mathrm{HS}^{-}+2 \mathrm{O}_{2}+\mathrm{H}_{2} \mathrm{O}^{-} \rightarrow \mathrm{SO}_{4}^{2-}+\mathrm{H}^{+}$ \\
\hline
\end{tabular}

The biogeochemical data were also used to calculate the ionic strength of the groundwater in each well and the respective activities coefficients of each reactant and product using Geochemist's Workbench (release 7.0) (RockWare, Inc., Golden, Colo.). The activity coefficients were used to adjust the concentrations of the constituents to their respective activities, and these activities were used in the biogeochemical reaction calculations, exemplified by

$$
a A+b B \rightleftarrows c C+d D,
$$

where

$A, B$ and $C, D$ represent the activities of the reactants and products, respectively, and $a, b, c, d \quad$ are the respective stoichiometric reaction constants from the balanced equations. The Gibbs free energies (in joules per mole), under standard conditions $\left(\Delta G^{\circ}\right)$ (that is, $298.15^{\circ} \mathrm{K}, 1.0$ atmosphere, $\mathrm{pH}=0$, ionic strength $=0$, and the concentrations of all reactants and products are 1.0 molar) were calculated for the balanced reactions, as follows:

$$
\Delta G^{\circ}=\sum \Delta G_{f}^{\circ}(\text { products })-\sum \Delta G_{f}^{\circ}(\text { reactants }),
$$

where $\Delta G_{f}^{\circ}$ (joules per mole) represents the standard free energy of formation values for the respective products and reactants in each reaction. The equilibrium constant $\left(K_{e q}\right)$ for each reaction was derived using the $\Delta G^{\circ}$ values from equation 4 and solving for $K_{e q}$ : 


$$
K_{e q}=e^{-\left(\Delta G^{\circ} / R T\right)},
$$

where

$R \quad$ is the universal gas constant $\left(8.3145\right.$ joules per degree Kelvin per mole $\left.\left(\mathrm{J}^{\circ} \mathrm{K}^{-1} \mathrm{~mol}^{-1}\right)\right)$, and $T \quad$ is temperature $\left({ }^{\circ} \mathrm{K}\right)$.

The $\Delta G^{\circ}$ data were used to calculate the free energy values under in situ conditions $\left(\Delta G_{r}\right)$ for each reaction using the groundwater temperatures (table 2 ) and activities of the reactants and products (table 3), denoted by square brackets, using the following relationship:

$$
\Delta G_{r}=\Delta G^{\circ}+R T \ln Q,
$$

where

$$
Q=\frac{[C]^{c}}{[A]^{a}} \frac{[D]^{d}}{[B]^{b}} .
$$

Each reaction was balanced and $\Delta G^{\circ}$ and $\Delta G_{r}$ values calculated using the CHNOSZ software package (Dick, 2008).

The quantity of energy that can be released from biogeochemical reactions can be assessed by comparing the energy available at equilibrium to the energy available under in situ conditions. A convenient method for doing these types of comparisons is chemical affinities $(A)$ (kilojoules per mole):

$$
A=R T \ln \frac{K_{e q}}{Q} .
$$

Positive chemical affinity values indicate the reaction, as written, will proceed to the right and release the calculated free energy for use by the members of the microbial community that are capable of performing that reaction.

The calculation of free energy yields provide insight into which of the biogeochemical reactions has the greatest likelihood of occurring under in situ conditions in the aquifers; however, these estimates do not indicate the rates at which the microorganisms acquire the necessary energy for cellular activities. Because molecular diffusion is the mechanism through which microorganisms obtain the required reactants for biogeochemical reactions, the limiting reactant's rate of diffusion from the groundwater to the microbial cell surface will equal the overall reaction rate (Schulz and Jorgensen, 2001).

The amount of energy the bacterial cell can potentially generate from performing the biogeochemical reaction, assuming the reaction rate is controlled by the limiting reactant, can be expressed as the steady state free energy flux ( $F E F$, in kilojoules per cell per second):

$$
F E F=4 \pi \cdot r \cdot D_{c} \cdot C \cdot \Delta G_{r},
$$

where

$r \quad$ is the radius (micrometers) of the microbial cell,

$D_{c} \quad$ (meters squared per second) is the diffusion coefficient of the limiting reactant,

$C \quad$ (moles per cubic meter) is the concentration of the limiting reactant, and

$\Delta G_{r} \quad$ is the free energy of reaction (kilojoules per cell per second) for the respective biogeochemical reactions. 
The relationship between the FEF and the list of biogeochemical reactions in table 3 is predicated on the use of the calculated free energy yields for the production of adenosine triphosphate (ATP) (Schink, 1997; Thauer and others, 1977). In addition to the dependence on diffusion rates, this relationship is based on the additional assumptions that the conservation of energy occurs through electron transport processes for all of the biogeochemical reactions shown in table 3 and that the conversion of this energy to ATP proceeds with maximum efficiency, which sets a minimum free energy yield for ATP production. This minimum free energy yield is commonly set at -20 kilojoules per mole $\left(\mathrm{kJ} \mathrm{mol}^{-1}\right)$ of limiting reactant. Accordingly, only those biogeochemical reactions whose $\Delta G r$ were $<-20 \mathrm{~kJ}$ mol-1 (that is, more negative) were used in the FEF calculations. The rate at which a cell can access the limiting reactant is expressed by the maximum acquisition rate ( $M A R$, in micromoles per day) (Onstott and others, 2006):

$$
M A R=4 \pi \cdot r \cdot D_{c} \cdot C \cdot B A,
$$

where $B A$ is the abundance of bacterial cells (cells per liter) in the respective groundwater samples.

\section{Microbial Community Diversity Sample Collection and Analyses}

Samples were collected from each well into sterile 20-L carboys during three sampling events (table 4). A cartridge filter (Sterivex GP, 0.22- $\mu$ m pore size; Millipore Corp., Mass.) was connected to each carboy and, under gravity-induced flow, allowed to filter until flow had stopped. After removing the cartridge filter, its protective plastic housing was aseptically removed and the filter transferred to a sterile container. All filters were stored at $-80^{\circ} \mathrm{C}$ in separate containers. All filters were shipped frozen and on dry ice to Second Genome, Inc. (San Bruno, Calif.) for DNA extraction, amplification, and application on their proprietary PhyloChip ${ }^{\mathrm{TM}}$ G3 Array technology. The PhyloChip G3 microarray is capable of identifying approximately 60,000 operational taxonomic units (OTU) that represent approximately

Table 4. Sample volumes for bacterial diversity analyses samples from the six sampling sites.

\begin{tabular}{cccc}
\hline Well site & Sample date & Volume collected (Liters) & Total volume (Liters) \\
\hline MZ1 & $8 / 3 / 2010$ & 7.3 & 18.4 \\
& $9 / 20 / 2010$ & 11.1 & \\
& & & 17.6 \\
MZ3 & $8 / 3 / 2010$ & 7.0 & \\
& $9 / 20 / 2010$ & 10.6 & 16.3 \\
$42 \mathrm{U}$ & $9 / 1 / 2010$ & 6.7 & \\
& $9 / 21 / 2010$ & 9.6 & 14.7 \\
$42 \mathrm{~L}$ & $9 / 1 / 2010$ & 5.2 & \\
& $9 / 21 / 2010$ & 9.5 & 17.9 \\
& & & \\
$15 \mathrm{U}$ & $9 / 1 / 2010$ & 5.9 & 17.7 \\
& $9 / 27 / 2010$ & 12.0 & \\
& & & \\
$15 \mathrm{M}$ & $9 / 1 / 2010$ & 5.7 & \\
& $9 / 27 / 2010$ & 12.0 & \\
\hline
\end{tabular}


840 subfamilies within the Eubacteria and Archaea kingdoms (DeSantis and others, 2007; Hazen and others, 2010). The coverage of total bacterial diversity by the PhyloChip G3 has been shown to be comparable to 454 pyrosequencing technology (DeAngelis and others, 2011).

DNA was isolated and polymerase chain reactions (PCR) were carried out using bacterial and archaeal primers. The eubacterial 16S rRNA genes were amplified using the degenerate forward primer, 27F.1 (5'-AGRGTTTGATCMTGGCTCAG-3'), and the nondegenerate reverse primer, 1492R (5'- GGTTACCTTGTTACGACTT-3'). The archaeal 16S rRNA genes were amplified using the degenerate forward primer, 4fa (5'-TCCGGTTGATCCTGCCRG-3'), and the nondegenerate reverse primer, 1492R (5'-GGTTACCTTGTTACGACTT-3') (Hazen and others, 2010). Twenty seven cycles of PCR for eubacterial 16S rRNA gene amplification and 32 cycles of PCR for archaeal 16S rRNA gene amplification was performed. For each sample, amplified products were concentrated by centrifuge filtration and quantified by electrophoresis using an Agilent 2100 Bioanalyzer. PhyloChip Control Mix was added to each amplified product.

PCR products from each sample were pooled, 5 parts to 1 part, and fragmented, biotin labeled, and hybridized to the PhyloChip Array, version G3. PhyloChip arrays were washed, stained, and scanned using a GeneArray ${ }^{\circledR}$ scanner, and each scan was captured using GeneChip ${ }^{\circledR}$ Microarray Analysis Suite (Affymetrix, Inc., Santa Clara, Calif.). Hybridization values, the fluorescence intensity, for each taxon were calculated as a trimmed average, with maximum and minimum values removed before averaging. To calculate the summary intensity for each feature on each array, the central nine pixels of individual features were ranked by intensity and the 75th percentile was used. Probe intensities were background-subtracted and scaled to the PhyloChip Control Mix. The hybridization score for an OTU was calculated as the mean intensity of the perfectly matching probes exclusive of the maximum and minimum.

The description and discussion of OTU data treat "bacteria" as an inclusive term for the eubacterial and archaeal OTUs. In this report, the term "bacteria" is used synonymously to describe the prokaryotes collectively, namely the members of the domains Bacteria (Eubacteria) and Archaea (Archaebacteria) (that is, organisms that are not eukaryotes). Although profound differences between Bacteria and Archaea are acknowledged, the two are quite similar with respect to basic cellular organization and general functional properties, such as biogeochemical processes in anaerobic systems. Because one of the objectives of this study was to characterize the functional diversity of prokaryotic communities and how these diversities influence groundwater geochemistry in the Upper Floridan aquifer, it was less important to, for example, describe which members of the Bacteria and Archaea reduce sulfate than to determine that sulfate reduction is energetically favorable, regardless of which members in each domain were driving the process.

\section{Statistical Analyses}

The presence and (or) absence microbial community diversity data generated from the PhyloChip G3 array for each groundwater sample were inter-compared in a pairwise fashion using the Sorensen index to determine dissimilarity scores, which were stored in a distance matrix. The statistical significance between comparisons was determined using the adonis test. These statistical analyses were conducted by Second Genome, Inc. 


\section{Results and Discussion}

\section{Water Quality}

The underlying hypothesis that the geochemistry of the Upper Floridan aquifer was relatively consistent between and within sample sites was tested using principal component analysis (PCA). A visual estimation of relatedness between sample sites can be made by comparing the relative closeness of the well site designations along the $\mathrm{x}$-axis (that is, PC1) and then the y-axis (that is, PC2) (figs 2-7).

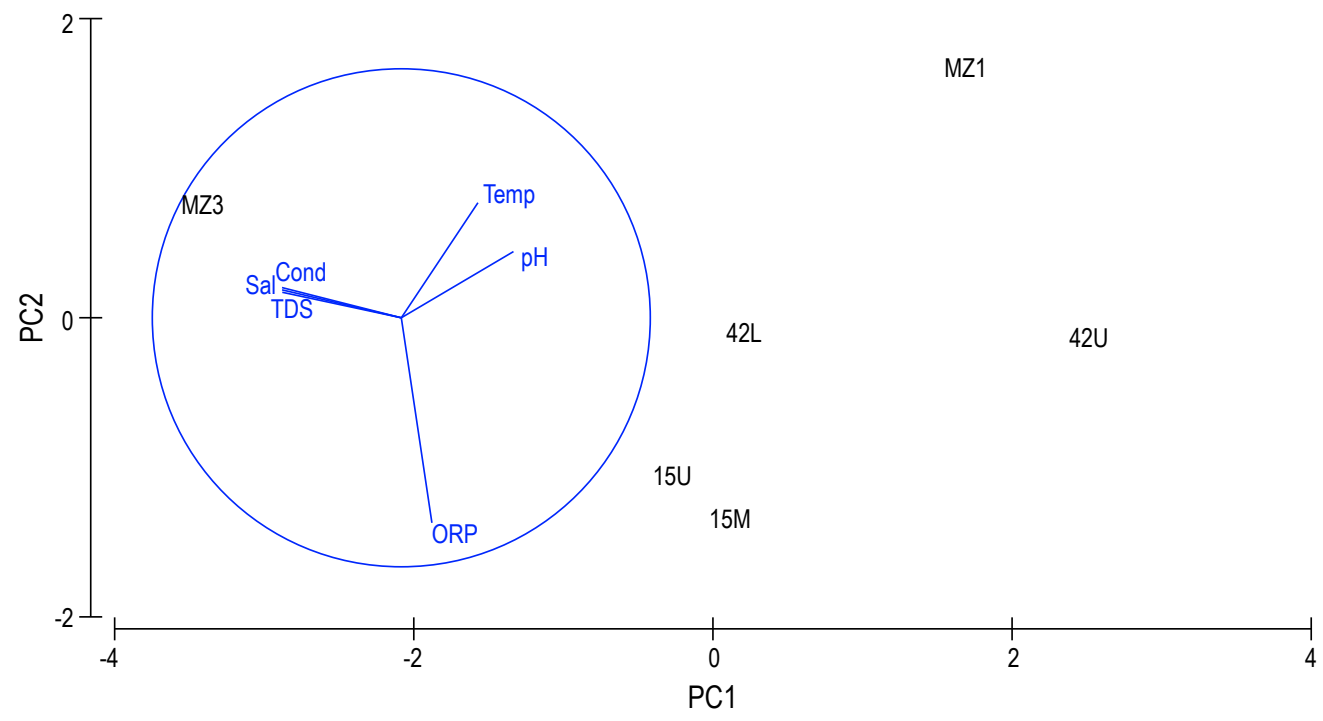

Figure 2. Graph showing principal component analysis of field data from the six sampling sites [PC1, principal component 1; PC2, principal component 2].

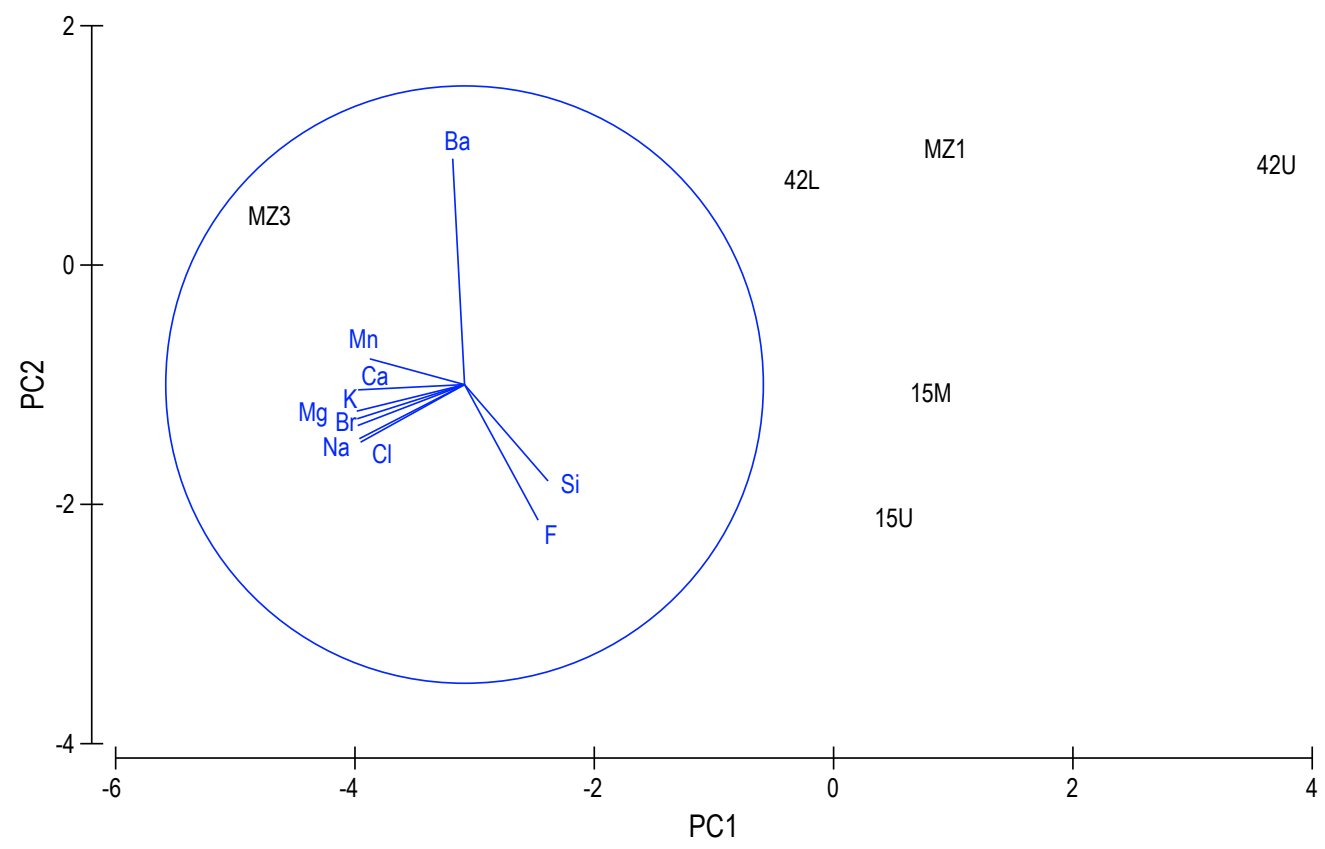

Figure 3. Graph showing principal component analysis of ionic species data from the six sampling sites [PC1, principal component 1; PC2, principal component 2]. 


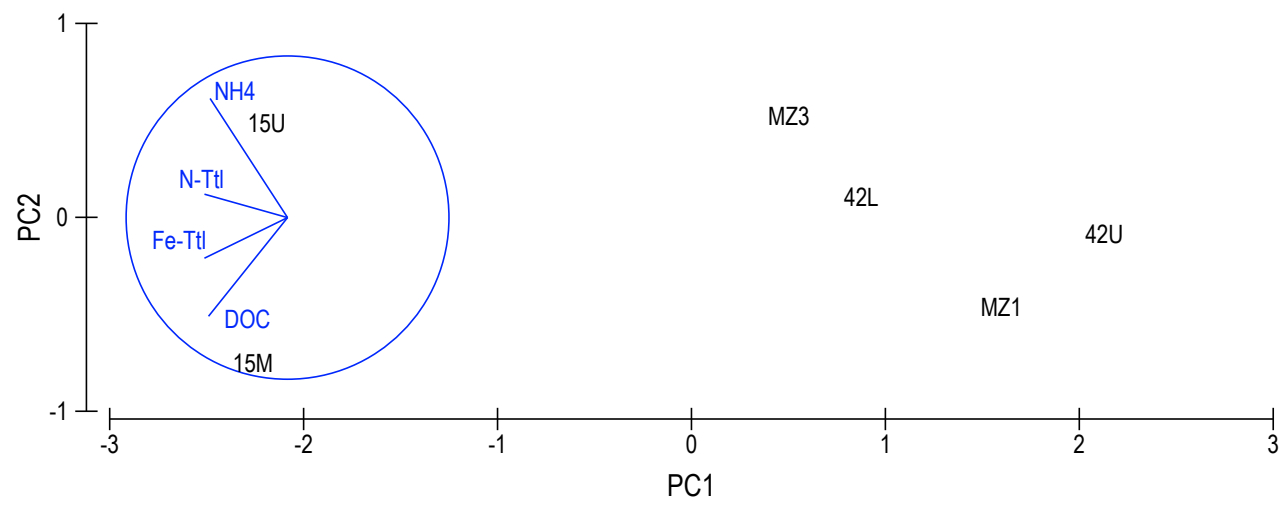

Figure 4. Graph showing principal component analysis of nutrient data from the six samplng sites [PC1, principal component 1; PC2, principal component 2] .

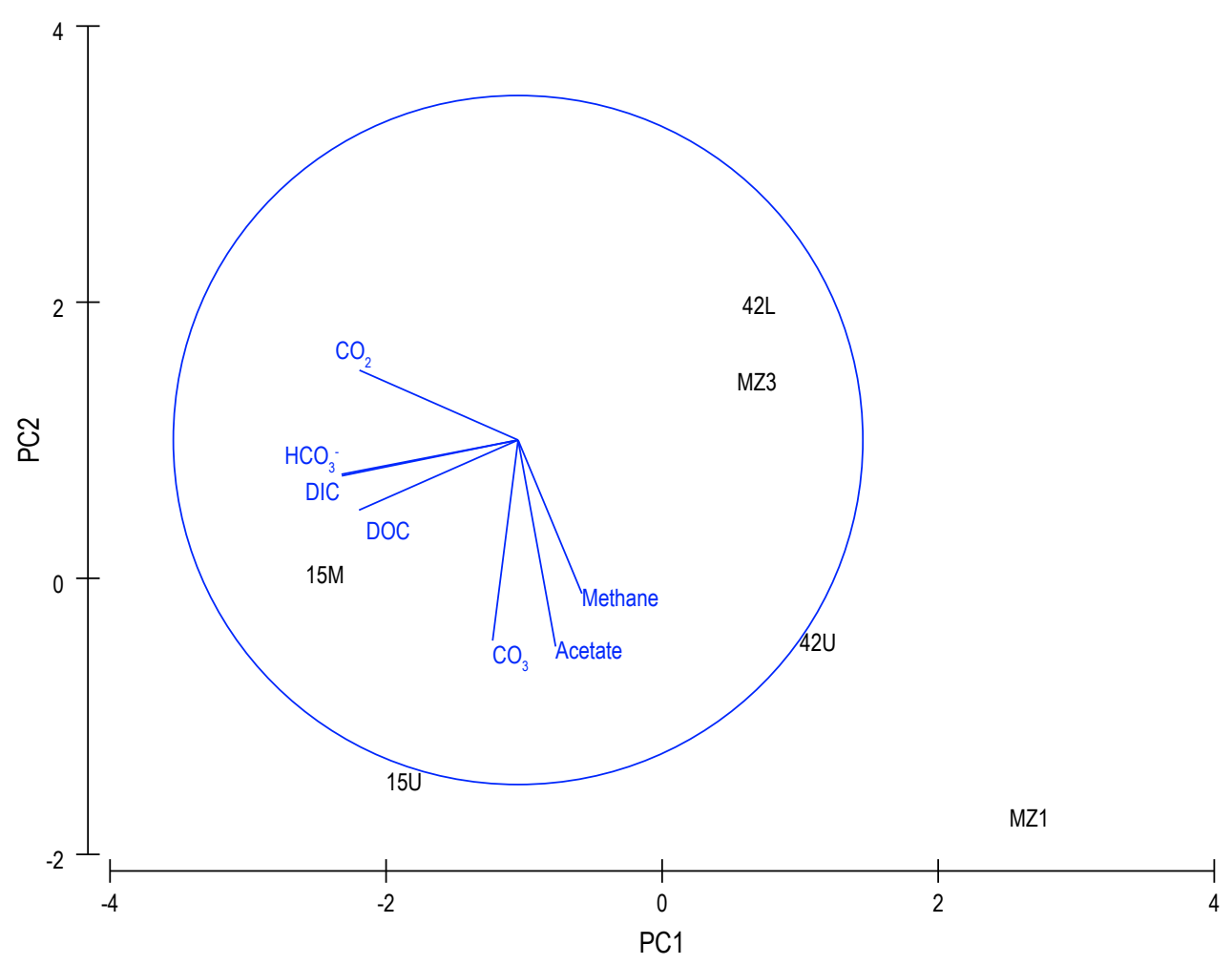

Figure 5. Graph showing principal component analysis of carbon substrate data from the six sampling sites [PC1, principal component 1; PC2, principal component 2] .

The proximity of well-site names along the respective axes is directly proportional to the similarity of their geochemical data (table 2). The interpretation of the PCA graphs for the water-quality variables is facilitated by the superimposition of the calculated eigenvectors (table 5), whose direction is most like the variable (for example, $\mathrm{pH}$ ) represented by the vector. The length of the vector is proportional to that variable's contribution to the overall variance; that is, the longer the vector, the more significant the influence of that variable on the overall variance.

The PCA was applied to subsets of the data in table 2. These data subsets were grouped as follows: field data (fig. 2), ionic geochemical species (fig. 3), nutrients (fig. 4), organic and inorganic carbon (fig. 5), geochemical constituents that predominate in terminal electron acceptor processes (TEAPs) (fig. 6), and the geochemical constituents that were used as the reactants and products in the energetics 

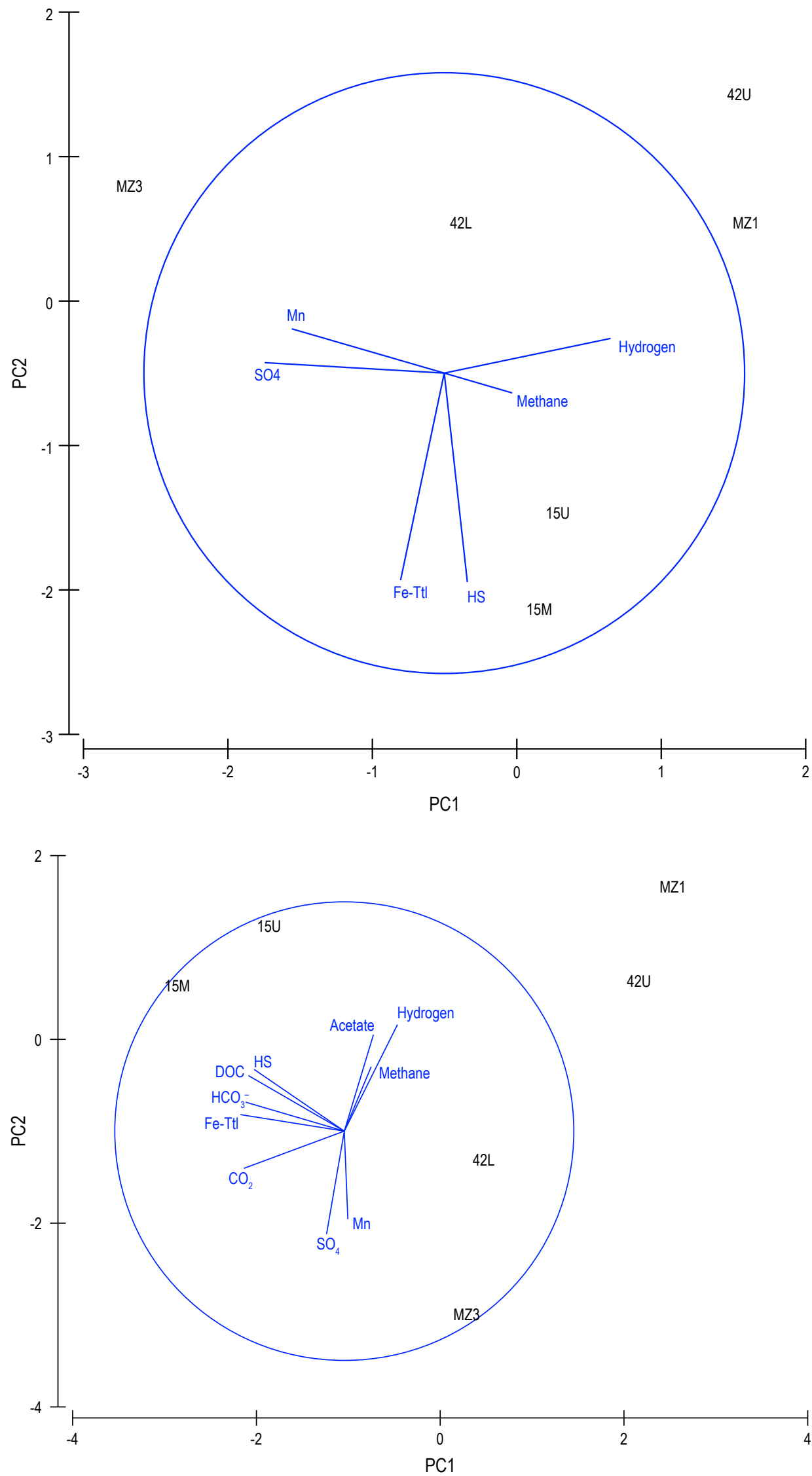

Figure 6. Graph showing principal component analysis of terminal electron acceptor data from the six sampling sites [PC1, principal component 1; PC2, principal component 2].
Figure 7. Graph showing principal component analysis of reactant data from the six sampling sites for the thermodynamically favorable biogeochemical reactions [PC1, principal component 1; PC2, principal component 2] . 
Table 5. Principal component analyses eigenvector data for the six sampling sites.

\begin{tabular}{|c|c|c|c|c|}
\hline \multirow{2}{*}{ Comparison group } & \multirow{2}{*}{ Variable } & \multirow{2}{*}{ Graph notation } & \multicolumn{2}{|c|}{ Principal components } \\
\hline & & & PC1 coefficients & PC2 coefficients \\
\hline \multirow[t]{6}{*}{ Field data } & Protons & $\mathrm{pH}$ & 0.450 & 0.266 \\
\hline & Temperature & Temp & 0.308 & 0.462 \\
\hline & Oxidation/reduction Potential & ORP & 0.123 & -0.823 \\
\hline & Conductivity & Cond & -0.478 & 0.102 \\
\hline & Total dissolved solids & TDS & -0.479 & 0.112 \\
\hline & Salinity & Sal & -0.479 & 0.121 \\
\hline \multirow[t]{10}{*}{ Ionic species } & Silica & $\mathrm{Si}$ & 0.279 & -0.323 \\
\hline & Fluorine & $\mathrm{F}$ & 0.246 & -0.454 \\
\hline & Potassium & $\mathrm{K}$ & -0.361 & -0.089 \\
\hline & Magnesium & $\mathrm{Mg}$ & -0.359 & -0.114 \\
\hline & Bromine & $\mathrm{Br}$ & -0.358 & -0.137 \\
\hline & Calcium & $\mathrm{Ca}$ & -0.356 & -0.018 \\
\hline & Sodium & $\mathrm{Na}$ & -0.352 & -0.181 \\
\hline & Chlorine & $\mathrm{Cl}$ & -0.348 & -0.193 \\
\hline & Manganese & $\mathrm{Mn}$ & -0.317 & 0.086 \\
\hline & Barium & $\mathrm{Ba}$ & -0.040 & 0.757 \\
\hline \multirow[t]{4}{*}{ Nutrients } & Ammonium & $\mathrm{NH} 4$ & -0.480 & 0.737 \\
\hline & Dissolved organic carbon & DOC & -0.490 & -0.610 \\
\hline & Total iron & Fe-Ttl & -0.515 & -0.251 \\
\hline & Total nitrogen & N-Ttl & -0.515 & 0.145 \\
\hline \multirow[t]{7}{*}{ Organic and inorganic carbon } & Bicarbonate & $\mathrm{HCO} 3-$ & 0.512 & -0.099 \\
\hline & Dissolved inorganic carbon & DIC & 0.511 & -0.104 \\
\hline & Dissolved organic carbon & DOC & 0.461 & -0.204 \\
\hline & Carbon dioxide & $\mathrm{CO} 2$ & 0.460 & 0.203 \\
\hline & Carbonate & $\mathrm{CO} 3$ & 0.074 & -0.582 \\
\hline & Acetate & Acetate & -0.109 & -0.599 \\
\hline & Methane & Methane & -0.185 & -0.446 \\
\hline \multirow{6}{*}{$\begin{array}{l}\text { Terminal electron acceptor process } \\
\text { substrates (TEAPs) }\end{array}$} & Di-hydrogen & Hydrogen & 0.554 & 0.115 \\
\hline & Methane & Methane & 0.226 & -0.066 \\
\hline & Hydrogen sulfide & HS & 0.077 & -0.696 \\
\hline & Total iron & $\mathrm{Fe}-\mathrm{Ttl}$ & -0.145 & -0.689 \\
\hline & Manganese & $\mathrm{Mn}$ & -0.508 & 0.147 \\
\hline & Sulfate & $\mathrm{SO} 4$ & -0.598 & 0.035 \\
\hline \multirow[t]{10}{*}{ Reactants } & Di-hydrogen & Hydrogen & 0.232 & 0.465 \\
\hline & Acetate & Acetate & 0.127 & 0.421 \\
\hline & Methane & Methane & 0.117 & 0.281 \\
\hline & Manganese & $\mathrm{Mn}$ & 0.015 & -0.385 \\
\hline & Sulfate & $\mathrm{SO} 4$ & -0.077 & -0.449 \\
\hline & Hydrogen sulfide & HS & -0.393 & 0.269 \\
\hline & Dissolved organic carbon & DOC & -0.418 & 0.242 \\
\hline & Bicarbonate & HCO3- & -0.430 & 0.126 \\
\hline & Carbon dioxide & $\mathrm{CO} 2$ & -0.438 & -0.163 \\
\hline & Total iron & $\mathrm{Fe}-\mathrm{Ttl}$ & -0.453 & 0.072 \\
\hline
\end{tabular}


Table 6. Principal component analyses percent variance per axis data for the six sampling sites. [TEAPs, terminal electron acceptor process substrates]

\begin{tabular}{lccc}
\hline \multirow{2}{*}{ Data sets } & \multicolumn{2}{c}{ Percent variation } & $\begin{array}{c}\text { Cumulative percent } \\
\text { variation }\end{array}$ \\
\cline { 2 - 3 } & PC 1 & PC 2 & 92.0 \\
Field data & 71.0 & 21.0 & 91.2 \\
Ionic species & 75.4 & 15.8 & 74.2 \\
TEAPs & 41.0 & 33.2 & 97.8 \\
Nutrients & 91.2 & 6.6 & 85.1 \\
Organic and inorganic carbon & 52.7 & 32.4 & 78.0 \\
Reactants & 45.9 & 32.1 & \\
\hline
\end{tabular}

calculations (fig. 7). The eigenvector loadings for the first two principal components (PC1 and PC2) for each of these comparisons are provided in table 5. Table 6 lists the respective contributions to the overall variance that each principal component represents. The cumulative percent variation represented by the first two principal components for each data comparison was relatively high, ranging from approximately 76 to 96 percent, indicating the relationships between variables are reasonably represented by $\mathrm{PC} 1$ and $\mathrm{PC} 2$ in the data distributions.

The field data coefficients for PC1 (table 5) indicate the horizontal relationships are best described by specific conductance, TDS, and salinity data at one extreme (negative coefficients) and $\mathrm{pH}$ (positive coefficient) at the other. The MZ3 site is most influenced by the variables related to specificconductance, whereas $42 \mathrm{U}$ is most influenced by $\mathrm{pH}$, relative to the other sites. The alignment of the other well sites between these two extremes indicates these sites are more related to each other and less related to the MZ3 and 42U sites (fig. 2). PC2 is dominated by ORP and, to a lesser extent, temperature (table 5). Figure 2 shows that the groundwater from $15 \mathrm{U}$ and $15 \mathrm{M}$ are similar and most influenced by ORP. Groundwater temperature separates MZ1 from the other wells, whereas 42U, 42L, and MZ3 are similar to each other in regard to the field data variables included in this analysis.

The ionic geochemical species, except for silica and fluorine, were all similarly weighted (table 5). The groundwater from MZ3 was most impacted by these constituents, whereas 42U was least influenced. The vertical distribution of the remaining sites indicates these groundwaters were all similar in regard to these ionic species. The PC2 data indicate that barium concentrations in MZ1, MZ3, 42U, and $42 \mathrm{~L}$ were similar and different from those in $15 \mathrm{U}$ and $15 \mathrm{M}$. The groundwater in $15 \mathrm{U}$ and $15 \mathrm{M}$ had relatively higher concentrations of silica and fluorine (fig. 3).

The groundwater nutrients were all similarly weighted for PC1. The groundwater from $15 \mathrm{U}$ and $15 \mathrm{M}$ were most similar to each other and dissimilar from MZ1, MZ3, 42U, and 42L. These similarities and differences are due to the relatively higher concentrations of all the nutrients in $15 \mathrm{U}$ and $15 \mathrm{M}$ groundwaters (table 5). PC2 was dominated by ammonium and total nitrogen at the upper end of the continuum and total iron and DOC at the lower end (fig. 4). This combination of nutrient factors shows $15 \mathrm{U}, \mathrm{MZ3}$, and 42L being relatively similar in their nitrogen-based nutrients and $15 \mathrm{M}, \mathrm{MZ1}$, and 42U being relatively similar in the DOC and total iron concentration (fig. 4).

The principal components for the inorganic and organic carbon data were weighted for the inorganic and dissolved organic carbon substrates that drive chemolithotrophic and heterotrophic metabolisms, respectively (table 5). In regard to PC1, MZ1 was most dissimilar to $15 \mathrm{U}$ and 15M, with the other three groundwater samples being similar to each other but slightly dissimilar to the groundwater at each extreme of the PC1 axis. PC2 is best described by the concentrations of methane, acetate, and carbonate (fig. 5). Samples from the APPZ from 15U, 42U, and MZ1 were most influenced by their respective 
concentrations of these organic and inorganic carbon substrates, which are known to be primary energy sources in anaerobic and reduced ecosystems like this region of the Upper Floridan aquifer.

The TEAPs PCA (fig. 6) shows that PC1 is dominated by hydrogen concentrations in the

groundwater, with all sites having higher concentrations relative to MZ3 grouped together (table 5). The total iron and sulfides data dominate PC2, with the higher concentrations of both in $15 \mathrm{U}$ and $15 \mathrm{M}$ driving their location as more dissimilar than the other four groundwater samples (fig. 6).

When assessing each groundwater for the constituents used in the biogeochemical reactions, PC1 is dominated by the inorganic carbon variables, total iron, and hydrogen sulfide concentrations (table 5). Again, 15U and 15M are similar and distinctly different from the remaining sites, which are more similar in their hydrogen, acetate, and methane concentrations (fig. 7). The relationships derived from PC2 are not as definitive (table 5); 42L and MZ3 are more similar in their sulfate and manganese concentrations, whereas the remaining sites are more similar in their hydrogen, acetate, and methane concentrations (fig. 7).

Collectively, the PCA analyses show that groundwaters within the UFA and APPZ are, as would be predicted, geochemically different. These zones are not homogenous on a regional basis, however, because there are significant differences in geochemistry between sites for a given zone. The types of water-quality variables (for example, methane, hydrogen, total inorganic carbon, acetate, sulfides, and ammonium) that show differences within and between zones in this region of the Upper Floridan aquifer indicate these differences are driven by microbial activities. The application of multivariate statistical analyses to geochemical data from groundwater samples provides (1) a quantitative platform for establishing native geochemical conditions and determining which variables are most influential in the aquifer, (2) baseline datasets to which temporally distinct data from the same site can be compared for determining if changes in geochemistry have occurred, and (3) a method to identify which geochemical variables change over time and the influence of those changes on the overall geochemistry following an event that disrupts the aquifer ecosystem (for example, aquifer recharge, storage and recovery, groundwater extraction, treated waste water injection, and carbon dioxide sequestration).

\section{Bacterial Abundances}

The mean bacterial abundances in all groundwater samples were relatively consistent, ranging from $3.92 \times 10^{4}$ to $8.01 \times 10^{5}$ cells $\mathrm{mL}^{-1}$ (table 7 ). These bacterial abundances are similar to those recovered from a series of samples collected from wells in the Upper Floridan aquifer located in central and south Florida (Lisle, 2005).

Additionally, native groundwater from each of the well sites was collected during each sampling event and filtered or directly plated onto each of the media used in the inactivation experiments. None

Table 7. Bacterial total direct count data for the six sampling sites.

\begin{tabular}{cl}
\hline Well site & Cells per milliliter \\
\hline $42 \mathrm{U}$ & $3.92 \times 10^{4} \pm 1.49 \times 10^{3}$ \\
$42 \mathrm{~L}$ & $4.12 \times 10^{5} \pm 3.32 \times 10^{4}$ \\
$15 \mathrm{U}$ & $7.21 \times 10^{5} \pm 7.80 \times 10^{4}$ \\
$15 \mathrm{M}$ & $7.28 \times 10^{5} \pm 8.10 \times 10^{4}$ \\
$\mathrm{MZ1}$ & $8.01 \times 10^{5} \pm 6.87 \times 10^{4}$ \\
$\mathrm{MZ3}$ & $6.79 \times 10^{5} \pm 3.84 \times 10^{4}$ \\
\hline
\end{tabular}


of the native water samples produced colonies on mTEC agar, an average of $0.7 \mathrm{CFU} \mathrm{mL}^{-1}$ (range: 0.04-1.1 CFU mL $\mathrm{m}^{-1}$ ) were recovered on the PIA agar and $0.7 \mathrm{CFU} \mathrm{mL}^{-1}$ (range: $0-1 \mathrm{CFU} \mathrm{mL}^{-1}$ ) on R2A agar; none of these colonies were identified. The recovery of culturable bacteria from the native waters on the nonselective PIA and R2A agars is not surprising because these groundwater systems contain viable bacteria and both media promote the recovery of heterotrophic bacteria, regardless of their identity. More importantly, the numbers of culturable bacteria on these media are not great enough to influence the colony counts of the $E$. coli or P. aeruginosa recovered from the diffusion chambers, even if a contamination event (such as a membrane rupture, chamber gasket leak, or contamination during chamber recovery) had occurred.

\section{Bacterial Indicator Inactivation}

The colony counts from each of the experiments were first $\log _{10}$-transformed and analyzed using a suite of bacterial inactivation models to determine the best-fit model. The biphasic model (Cerf, 1977) provided the best fit for all datasets based on root mean sum of squared error (RMSE) values (data not shown).

This biphasic model describes the inactivation of bacterial communities that can be subdivided into two subpopulations. One subpopulation is more susceptible to inactivation than the other, which generates an inactivation curve with an initial steep and negative slope that follows into a tail with a significantly smaller negative slope. The two subpopulations are assumed to be independently and irreversibly inactivated with the respective inactivation rates following first order reaction kinetics. The equation for this inactivation model is

$$
\frac{N_{t}}{N_{0}}=f e^{-k_{1} t}+(1-f) e^{-k_{2} t},
$$

where

$N_{0}$ and $N_{t} \quad$ are the $\log _{10}$-transformed colony counts at time zero and time $t$, respectively;

$t \quad$ is the elapsed time (hours);

$f \quad$ is the decimal fraction of the total bacterial community in the major subpopulation that is inactivated at a higher rate (that is, less resistant $)\left(k_{1} ; \log _{10} \mathrm{CFU}\right.$ per milliliter per hour); and

$(1-f) \quad$ is the decimal fraction of the total bacterial community in the minor subpopulation that is inactivated at a slower rate (that is, more resistant) $\left(k_{2} ; \log _{10}\right.$ CFU per milliliter per hour); the higher the $k$-value, the faster the inactivation rate.

An estimation of the time required for a $1.0 \log _{10}$ reduction $\left(t_{\log _{10}}\right)$ in the two bacterial subpopulations was derived using the following relationship:

$$
t_{\log _{10}}=2.303 / k_{n},
$$

where $k_{\mathrm{n}}$ is the $k_{1}$ or $k_{2}$ inactivation rate (table 8 ). The calculated inactivation curves for each experiment are given for $E$. coli in figures 8-10 and $P$. aeruginosa in figures 11-13. The general biphasic curve shape is evident in each dataset. Table 8 lists the data for each of the inactivation relevant variables described for the biphasic equation. 
Table 8. Biphasic inactivation rate curve data for Escherichia coli and Pseudomonas aeruginosa from the six sampling sites.

$\left[\mathrm{k}_{1}\right.$ and $\mathrm{k}_{2}$, inactivation rate constants; $f$, decimel fraction of total bacterial counts; $\mathrm{t}_{\log 10}$, time to achieve a one $\log$ reduction in bacterial cell counts; ${ }^{-1}$, per hour; \%, percent; hrs, hours]

\begin{tabular}{|c|c|c|c|c|c|c|c|c|c|}
\hline \multirow{2}{*}{ Indicator bacterium } & \multirow{2}{*}{ Medium } & \multirow{2}{*}{ Variable } & \multirow{2}{*}{ Units } & \multicolumn{6}{|c|}{ Well designation } \\
\hline & & & & $42 U$ & $42 \mathrm{~L}$ & $15 U$ & $15 \mathrm{M}$ & MZ1 & MZ3 \\
\hline \multirow[t]{12}{*}{ Escherichia coli } & mTEC & $\mathrm{k}_{1}$ & $\mathrm{hr}^{-1}$ & 0.2950 & 0.6842 & 0.2171 & 0.5400 & 0.6275 & 0.5642 \\
\hline & & $\mathrm{f}$ & $\%$ & 98.3 & 95.9 & 99.8 & 99.0 & 98.3 & 98.8 \\
\hline & & $t_{\log 10}$ & hrs & 7.8 & 3.4 & 10.6 & 4.3 & 3.7 & 4.1 \\
\hline & & $\mathrm{k}_{2}$ & $\mathrm{hr}^{-1}$ & 0.0088 & 0.0182 & 0.0064 & 0.0135 & 0.0112 & 0.0125 \\
\hline & & $1-f$ & $\%$ & 1.7 & 4.1 & 0.2 & 1.0 & 1.5 & 1.2 \\
\hline & & $t_{\log 10}$ & days & 11.0 & 5.3 & 15.1 & 7.1 & 8.6 & 7.7 \\
\hline & $\mathrm{R} 2 \mathrm{~A}$ & $\mathrm{k}_{1}$ & $\mathrm{hr}^{-1}$ & 0.1850 & 0.1721 & 0.2013 & 0.1950 & 0.6063 & 0.2550 \\
\hline & & $\mathrm{f}$ & $\%$ & 98.2 & 99.6 & 99.6 & 99.5 & 99.5 & 99.8 \\
\hline & & $t_{\log 10}$ & hrs & 12.5 & 13.4 & 11.4 & 11.8 & 3.8 & 9.0 \\
\hline & & $\mathrm{k}_{2}$ & $\mathrm{hr}^{-1}$ & 0.0065 & 0.0003 & $<0.0001$ & 0.0026 & 0.0080 & 0.0035 \\
\hline & & $1-f$ & $\%$ & 1.8 & 0.4 & 0.4 & 0.5 & 0.5 & 0.2 \\
\hline & & $t_{\log 10}$ & days & 14.7 & 329.0 & $>959.58$ & 36.6 & 12.1 & 27.1 \\
\hline \multirow[t]{12}{*}{ Pseudomonas aeruginosa } & PIA & $\mathrm{k}_{1}$ & $\mathrm{hr}^{-1}$ & 0.7696 & 0.6917 & 0.1442 & 0.1592 & 0.3871 & 0.7717 \\
\hline & & $\mathrm{f}$ & $\%$ & 70.9 & 78.2 & 98.2 & 94.0 & 97.0 & 95.6 \\
\hline & & $t_{\log 10}$ & hrs & 3.0 & 3.3 & 16.0 & 14.5 & 6.0 & 3.0 \\
\hline & & $\mathrm{k}_{2}$ & $\mathrm{hr}^{-1}$ & 0.0048 & 0.0044 & 0.0034 & 0.0054 & 0.0080 & 0.0050 \\
\hline & & $1-f$ & $\%$ & 29.1 & 21.8 & 1.8 & 6.0 & 3.0 & 4.4 \\
\hline & & $t_{\log 10}$ & days & 20.0 & 21.9 & 28.1 & 17.7 & 12.0 & 19.4 \\
\hline & $\mathrm{R} 2 \mathrm{~A}$ & $\mathrm{k}_{1}$ & $\mathrm{hr}^{-1}$ & 0.2917 & 0.0479 & 0.4696 & 0.6833 & 0.6213 & 0.6704 \\
\hline & & $\mathrm{f}$ & $\%$ & 83.9 & 86.0 & 96.7 & 92.8 & 97.3 & 96.7 \\
\hline & & $t_{\log 10}$ & hrs & 7.9 & 48.1 & 4.9 & 3.4 & 3.7 & 3.4 \\
\hline & & $\mathrm{k}_{2}$ & $\mathrm{hr}^{-1}$ & 0.0041 & 0.0040 & 0.0023 & 0.0047 & 0.0094 & 0.0074 \\
\hline & & $1-f$ & $\%$ & 16.1 & 14.0 & 3.3 & 7.2 & 2.7 & 3.3 \\
\hline & & $t_{\log 10}$ & days & 23.3 & 23.7 & 41.9 & 20.4 & 10.2 & 12.9 \\
\hline
\end{tabular}

\section{Escherichia coli Inactivation}

The E. coli inactivation rates (that is, loss of cultivability over time) calculated from the mTEC agar data for the most susceptible subpopulation $\left(\mathrm{k}_{1}\right)$ were relatively consistent for $42 \mathrm{~L}\left(0.6842 \mathrm{~h}^{-1}\right)$, $15 \mathrm{M}\left(0.5400 \mathrm{~h}^{-1}\right)$, MZ1 $\left(0.6275 \mathrm{~h}^{-1}\right)$, and MZ3 $\left(0.5642 \mathrm{~h}^{-1}\right)($ table 8$)$. The inactivation rates in $42 \mathrm{U}\left(0.2950 \mathrm{~h}^{-1}\right)$ and $15 \mathrm{U}\left(0.2171 \mathrm{~h}^{-1}\right)$ were approximately 2 to 3 times slower. When expressing the inactivation rates as time required for a $1.0 \log _{10}$ reduction in $\mathrm{CFU} \mathrm{mL} \mathrm{mL}^{-1}\left(t_{\log _{10}}\right)$, the most sensitive $E$. coli subpopulation required between 3.4 and 10.6 hours (table 8 ). 

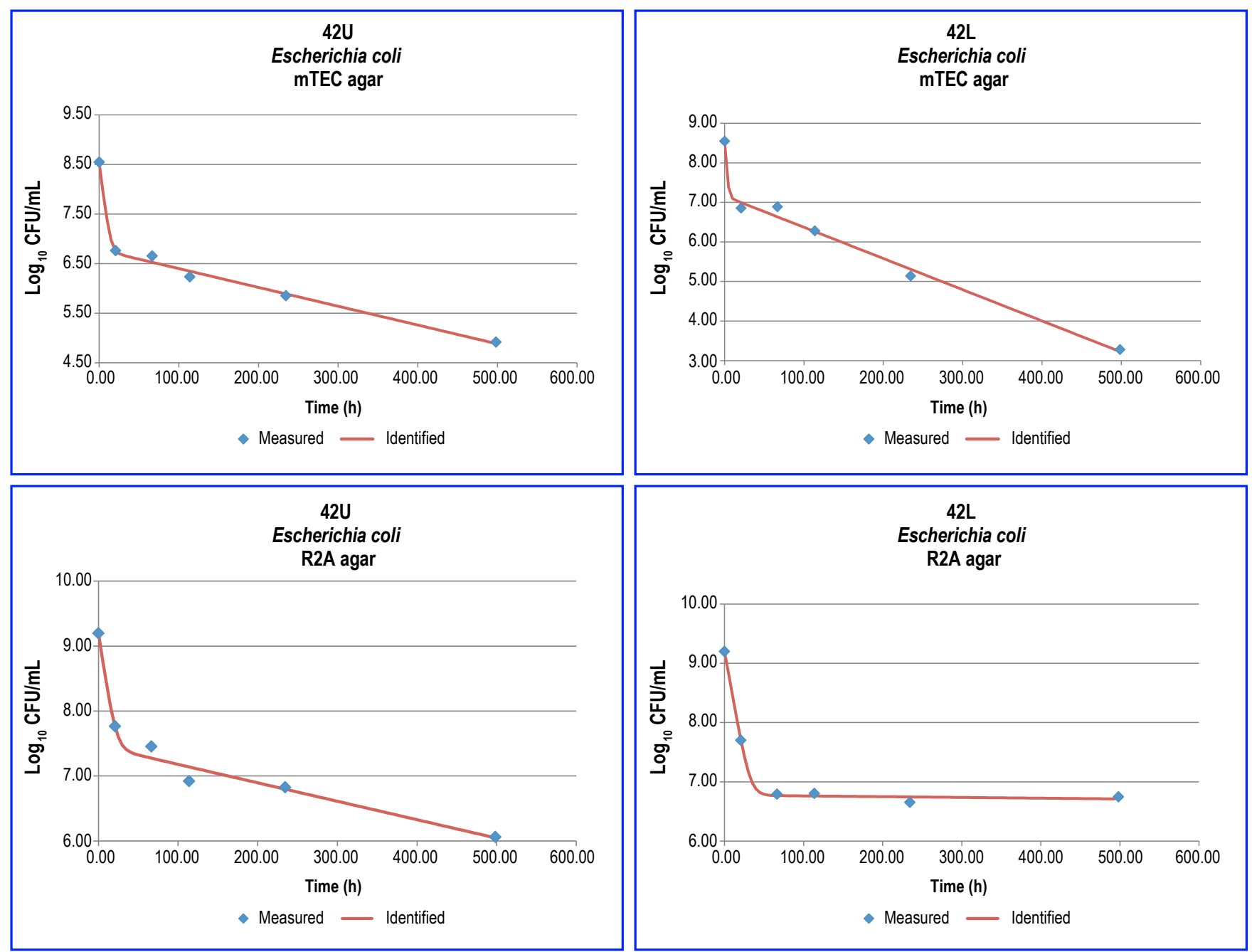

Figure 8. Graphs showing Escherichia coli decay rates for the $42 \mathrm{U}$ and $42 \mathrm{~L}$ sampling sites $\left[\log _{10} \mathrm{CFU} / \mathrm{mL}\right.$, $\log _{10}$ colony-forming units per milliliter; $h$, hours].

The inactivation rates for the less susceptible E. coli population $\left(k_{2}\right)$ followed a similar ranking as those for $k_{1}$, but the rates were between approximately 33 to 56 times slower (table 8). The times required for a $1.0 \log _{10}$ reduction were similar for $42 \mathrm{~L}, 15 \mathrm{M}, \mathrm{MZ1}$, and MZ3 (range: 5.3-8.6 d) and approximately two times slower than the other groundwater for 42U (11.0 d) and 15U (15.1 d) (table 8).

The $E$. coli $k_{1}$ inactivation rates calculated from the R2A agar data also were relatively consistent, ranging between 0.1721 and $0.2550 \mathrm{~h}^{-1}$, except for MZ1 (0.6063) (table 8). These rates are between 1.0 to 4.0 times slower than the $k_{1}$ values for the same groundwater on mTEC agar. The $k_{1}$ rates for the R2A agar data are between 1.1 to 4.0 times slower than the respective $k_{1}$ rates on mTEC agar (table 8). The time required for a $1.0 \log _{10}$ reduction on R2A agar for this subpopulation was similar to that on mTEC agar, ranging from 3.8 to 13.4 hours (table 8 ).

The inactivation rates for the less susceptible $E$. coli populations $\left(k_{2}\right)$ on R2A agar for $15 \mathrm{M}$, $\mathrm{MZ1}$, and MZ3 were approximately 72 to 75 times slower than their respective $k_{1}$ rates, whereas the $42 \mathrm{~L}$ rate was 590 times slower (table 8 ). The $k_{2}$ rate in the groundwater from $15 \mathrm{U}$ was approximately 2,000 times slower than the $k_{1}$ value because of the persistent culturability of this strain of $E$. coli after the initial inactivation event (table 8 ). When compared to the $k_{2}$ values from the mTEC agar data, the 

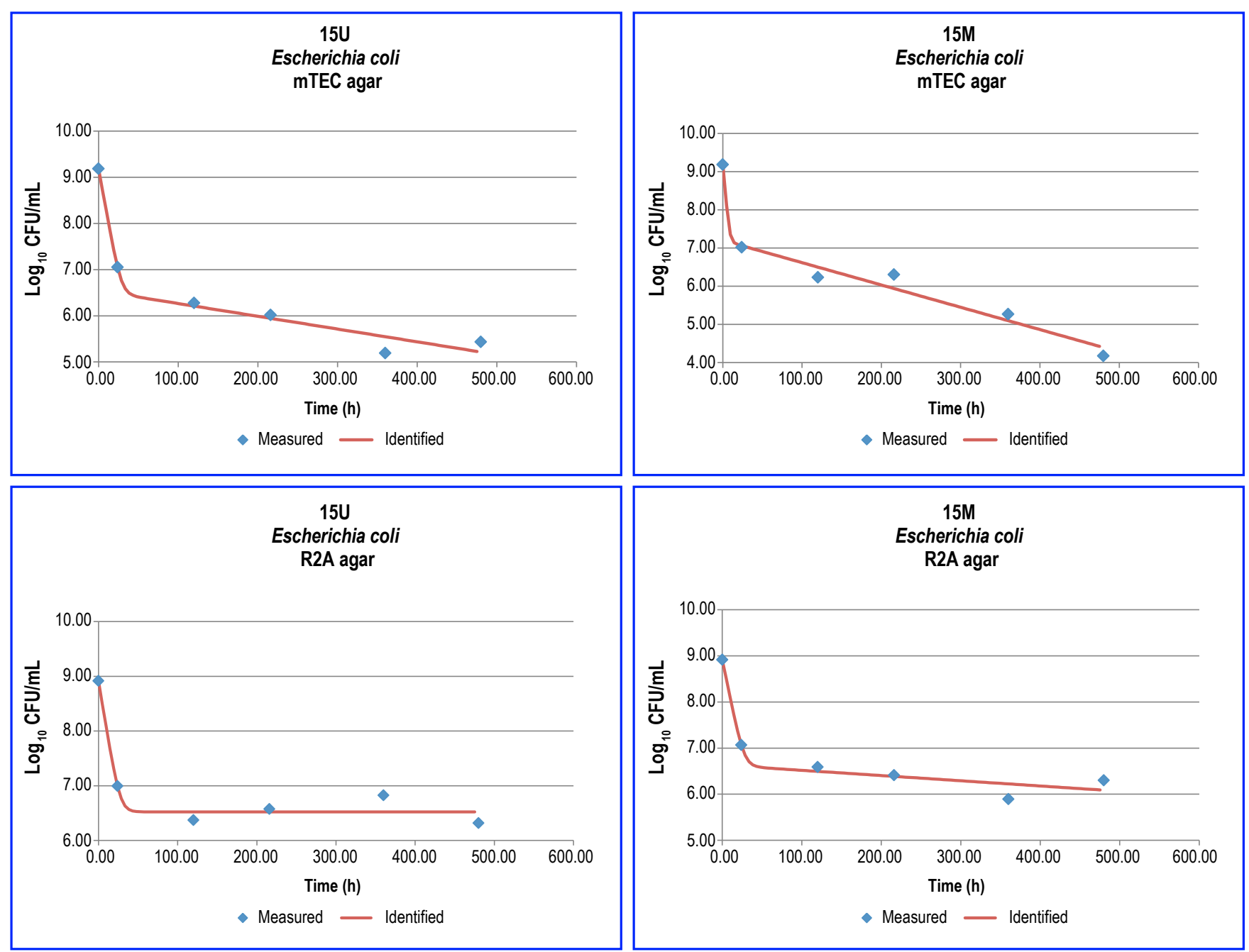

Figure 9. Graphs showing Escherichia coli decay rates for the $15 \mathrm{U}$ and $15 \mathrm{M}$ sampling sites $\left[\log _{10} \mathrm{CFU} / \mathrm{mL}, \log _{10}\right.$ colony-forming units per milliliter; $h$, hours].

values from the R2A agar data are between 1.3 and 5.1 times slower for 42U, 15M, MZ1, and MZ3 and approximately 63 times slower for $42 \mathrm{~L}$ and $15 \mathrm{U}$. Although the $1.0 \log _{10}$ reduction times for the more susceptible subpopulations were similar between mTEC and R2A agars, this was not the case for the more resistant subpopulations at all of the well sites. 42U (14.7 days) and MZ1 (12.1 days) were similar to each other and their respective mTEC agar data. It took approximately a month to achieve this level of inactivation at 15M (36.6 days) and MZ3 (27.1 days). The significantly lower inactivation rate for $42 \mathrm{~L}$ and persistent culturability recorded in $15 \mathrm{U}$ provided estimated $1.0 \log _{10}$ reduction times of 329 days and $>960$ days, respectively.

The differences in inactivation rates and times between mTEC agar and R2A agar, regardless of the groundwater source, can be partially attributed to the different compositions of the media. mTEC agar is a selective and differential medium whose formulation and incubation conditions (that is, elevated temperature) were specifically designed to preferentially recover $E$. coli in water samples while inhibiting the growth of all other bacteria (Zimbro and others, 2009). Additionally, mTEC agar contains a chromogenic substrate that, when catabolized by E. coli, imparts a diagnostic color to each colony, whereas colonies formed by other bacteria remain colorless. Collectively, these conditions also apply 

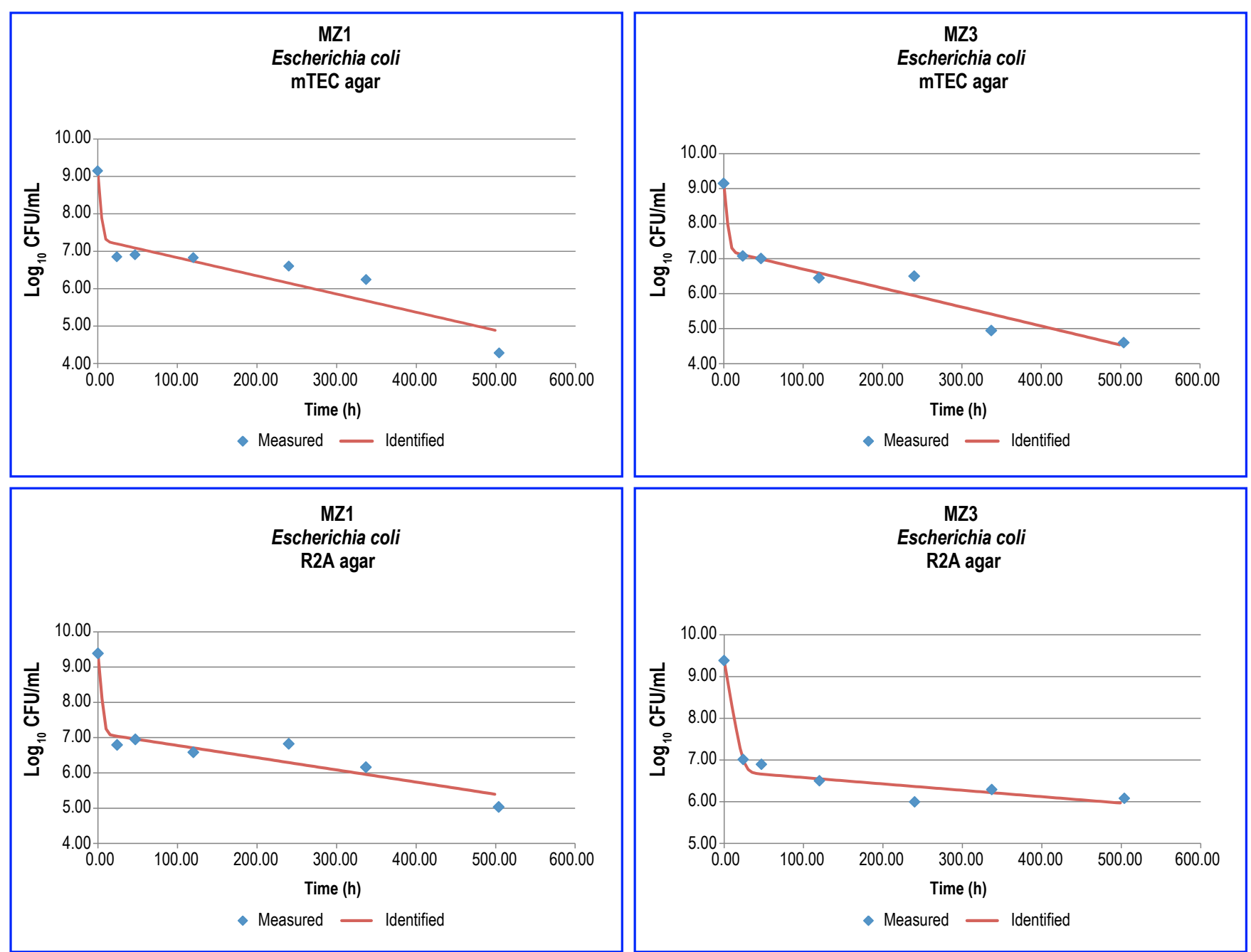

Figure 10. Graph showing Escherichia coli decay rates for the MZ1 and MZ3 sampling sites $\left[\log _{10} \mathrm{CFU} / \mathrm{mL}\right.$, log 10 colony-forming units per milliliter; $h$, hours].

additional physiological stresses on $E$. coli cells that have been shown to reduce bacterial recovery efficiencies, resulting in lower final CFU mL ${ }^{-1}$ values (Bissonnette and others, 1975; LeChevallier and others, 1983; McFeters, 1990). On the contrary, the formulation of R2A agar was designed to minimize the physiological stresses from incubation conditions, components of the recovery media, disinfectants, and environmental conditions, thereby increasing the recovery of injured and non-injured bacteria from water samples (Reasoner and Geldreich, 1985). R2A agar is a nonselective medium that contains reduced concentrations of nutrients that are essential for bacterial growth under environmental stress (that is, natural conditions) and following disinfection. Recovery rates of all heterotrophic bacteria are enhanced on this medium if incubated at lower temperatures, as described for this study. R2A agar has been used to compare recovery rates of $E$. coli and other bacteria of public health concern to those on selective media following starvation and disinfection (Keswick and others, 1982; Lisle and others, 1998).

\section{Pseudomonas aeruginosa Inactivation}

The $\mathrm{k}_{1}$ inactivation rates calculated from the PIA agar data for $P$. aeruginos $a$ were relatively similar for $42 \mathrm{U}\left(0.7696 \mathrm{~h}^{-1}\right), 42 \mathrm{~L}\left(0.6917 \mathrm{~h}^{-1}\right)$, and $\mathrm{MZ3}\left(0.7717 \mathrm{~h}^{-1}\right)$, with $15 \mathrm{U}\left(0.1442 \mathrm{~h}^{-1}\right)$ and 

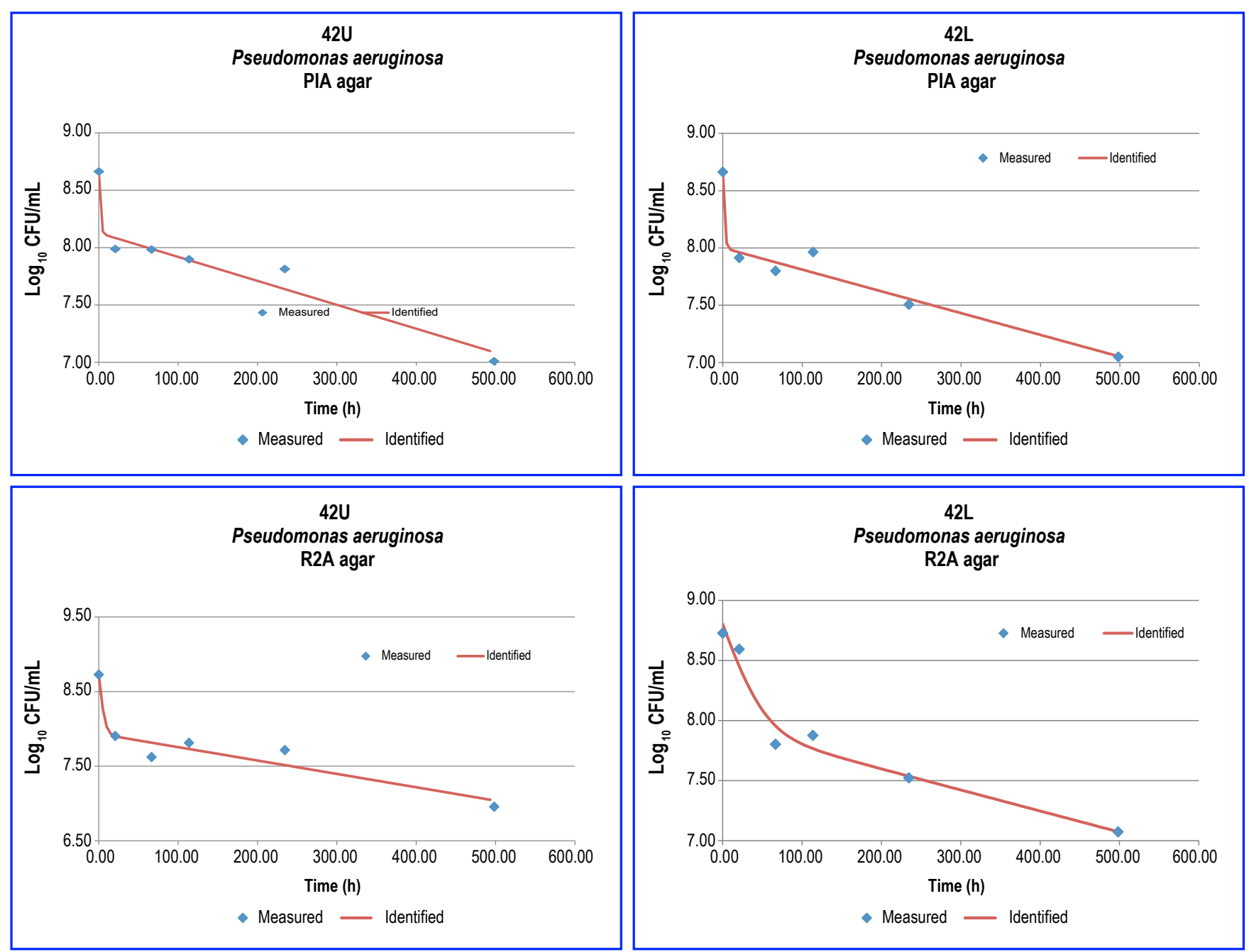

Figure 11. Graph showing Pseudomonas aeruginosa decay rates for the $42 \mathrm{U}$ and $42 \mathrm{~L}$ sampling sites $\left[\log _{10} \mathrm{CFU} / \mathrm{mL}, \log _{10}\right.$ colony-forming units per milliliter; $h$, hours].

$15 \mathrm{M}\left(0.1592 \mathrm{~h}^{-1}\right)$ being approximately 5 times slower and MZ1 $\left(0.3871 \mathrm{~h}^{-1}\right)$ positioned between the two sets of inactivation rates (table 8). The more susceptible subpopulations in the 42U, 42L, MZ1, and MZ3 diffusion chambers had similar $1.0 \log _{10}$ reduction times, ranging from 3.0 to $6.0 \mathrm{~h}$ (table 8 ). These reduction times were 2 to 5 times slower for $15 \mathrm{U}(16.0 \mathrm{~h})$ and $15 \mathrm{M}(14.5 \mathrm{~h})$ (table 8).

The $k_{2}$ inactivation rates from these same experiments were similar for $42 \mathrm{U}, 42 \mathrm{~L}, 15 \mathrm{U}, 15 \mathrm{M}$, and MZ3 (range: $\left.0.0034-0.0054 \mathrm{~h}^{-1}\right)$, with MZ1 being moderately higher $\left(0.0080 \mathrm{~h}^{-1}\right)$ (table 8$)$. The $k_{2}$ inactivation rates were 29.4 to 48.4 times slower than the respective $k_{1}$ rates for $15 \mathrm{M}, 15 \mathrm{U}$, and MZ1 and 155.6 to 160.6 times slower for MZ3, 42U, and 42L (table 8). The $t_{\log _{10}}$ values were grouped by site as for the $\mathrm{k}_{2}$ rates, ranging from 17.7 to 28.1 days, with MZ1 having a moderately faster rate of 12.0 days.

The $k_{1}$ inactivation rates for P. aeruginos $a$ on R2A agar were similar and relatively greater for $15 \mathrm{M}\left(0.6833 \mathrm{~h}^{-1}\right), \mathrm{MZ} 1\left(0.6213 \mathrm{~h}^{-1}\right)$, and MZ3 $\left(0.6704 \mathrm{~h}^{-1}\right)$. The $k_{1}$ rate for $15 \mathrm{U}\left(0.4696 \mathrm{~h}^{-1}\right)$ was slightly slower than the other rates, whereas the $42 \mathrm{U}\left(0.2917 \mathrm{~h}^{-1}\right)$ and $42 \mathrm{~L}\left(0.0479 \mathrm{~h}^{-1}\right)$ rates were significantly slower (table 8$)$. The $k_{2}$ inactivation rates were similar and relatively greater for MZ1 $\left(0.0094 \mathrm{~h}^{-1}\right)$ and MZ3 $\left(0.0074 \mathrm{~h}^{-1}\right)$, which were approximately two times greater than the rates from 42U $(0.0041$ $\left.\mathrm{h}^{-1}\right), 42 \mathrm{~L}\left(0.0040 \mathrm{~h}^{-1}\right)$, and $15 \mathrm{M}\left(0.0047 \mathrm{~h}^{-1}\right)$ and four times greater than $15 \mathrm{U}\left(0.0023 \mathrm{~h}^{-1}\right)($ table 8$)$. 

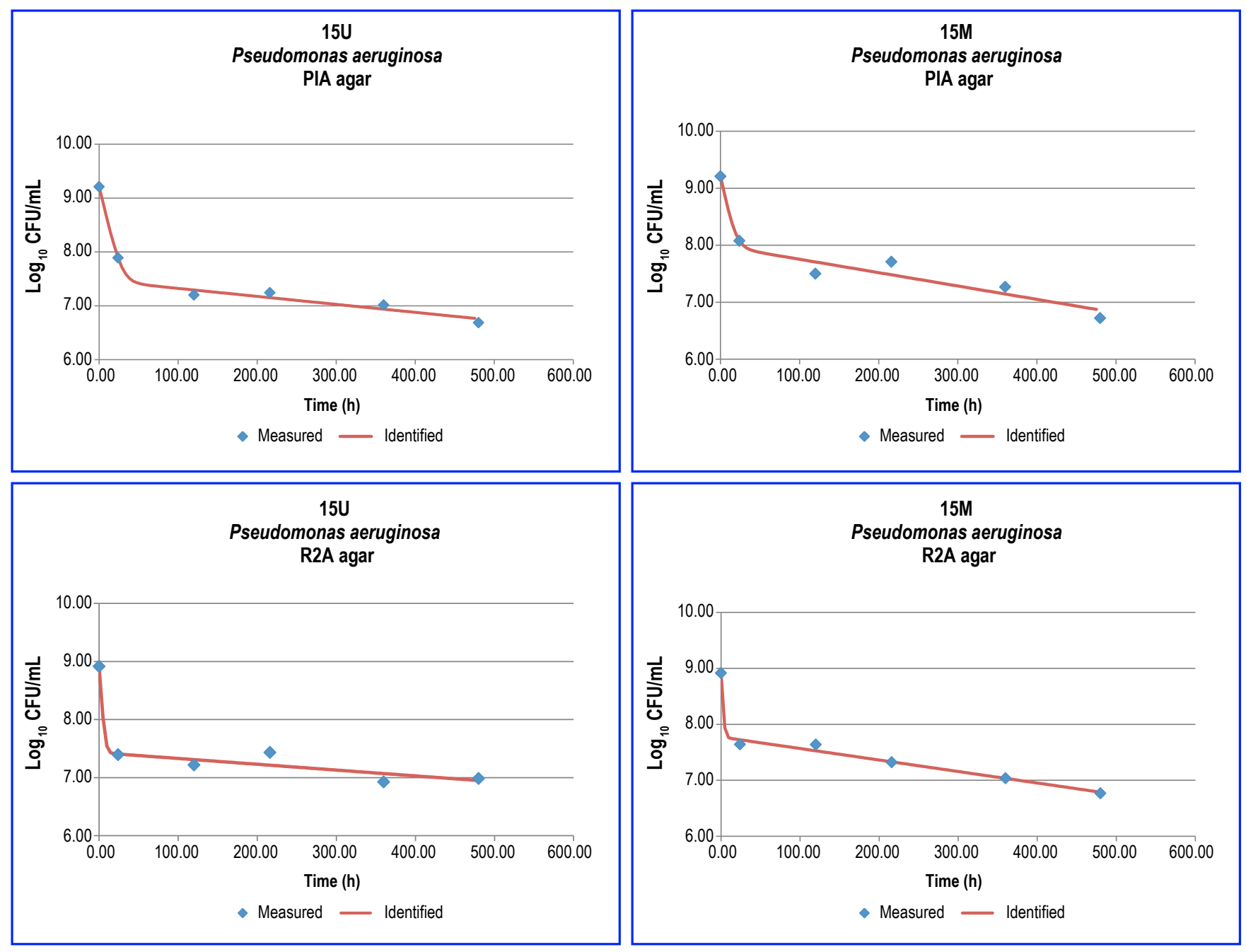

Figure 12. Graph showing Pseudomonas aeruginosa decay rates for the $15 \mathrm{U}$ and $15 \mathrm{M}$ sampling sites $\left[\log _{10} \mathrm{CFU} / \mathrm{mL}, \log _{10}\right.$ colony-forming units per milliliter; $h$, hours].

This second phase of the respective inactivation models was between approximately 12 times (42L) and 205 times (15U) slower than the respective $k_{1}$ inactivation rates (table 8). The time periods for a $1.0 \log _{10}$ reduction of the more susceptible subpopulations on R2A agar were not consistently similar to those from the PIA agar data, except for MZ3 (3.4 and 3.0 h, respectively) (table 8). Unlike the systematic differences between these same rates on mTEC and R2A agars, where the R2A agar data were all slower (with the exception of MZ1), some of the $t_{\log _{10}}$ rates from the PIA agar were greater than those on R2A agar (15U, 15M, and MZ1), whereas those for 42U and 42L were significantly slower (table 8).

PIA agar is also a selective and differential medium but the selective agents are not identical to those in mTEC agar in regard to their structures, activities, and degrees of inhibition (Zimbro and others, 2009). The higher incubation temperature for mTEC agar also increases the inhibitory effects. Collectively, the media formulation of and incubation conditions for mTEC agar exerts a significantly greater level of physiological stress on target bacteria than PIA agar. The lack of consistent differences between the recovery and inactivation data for PIA and R2A agars, as with the mTEC and R2A agar data, are due to the lower physiological stresses. 

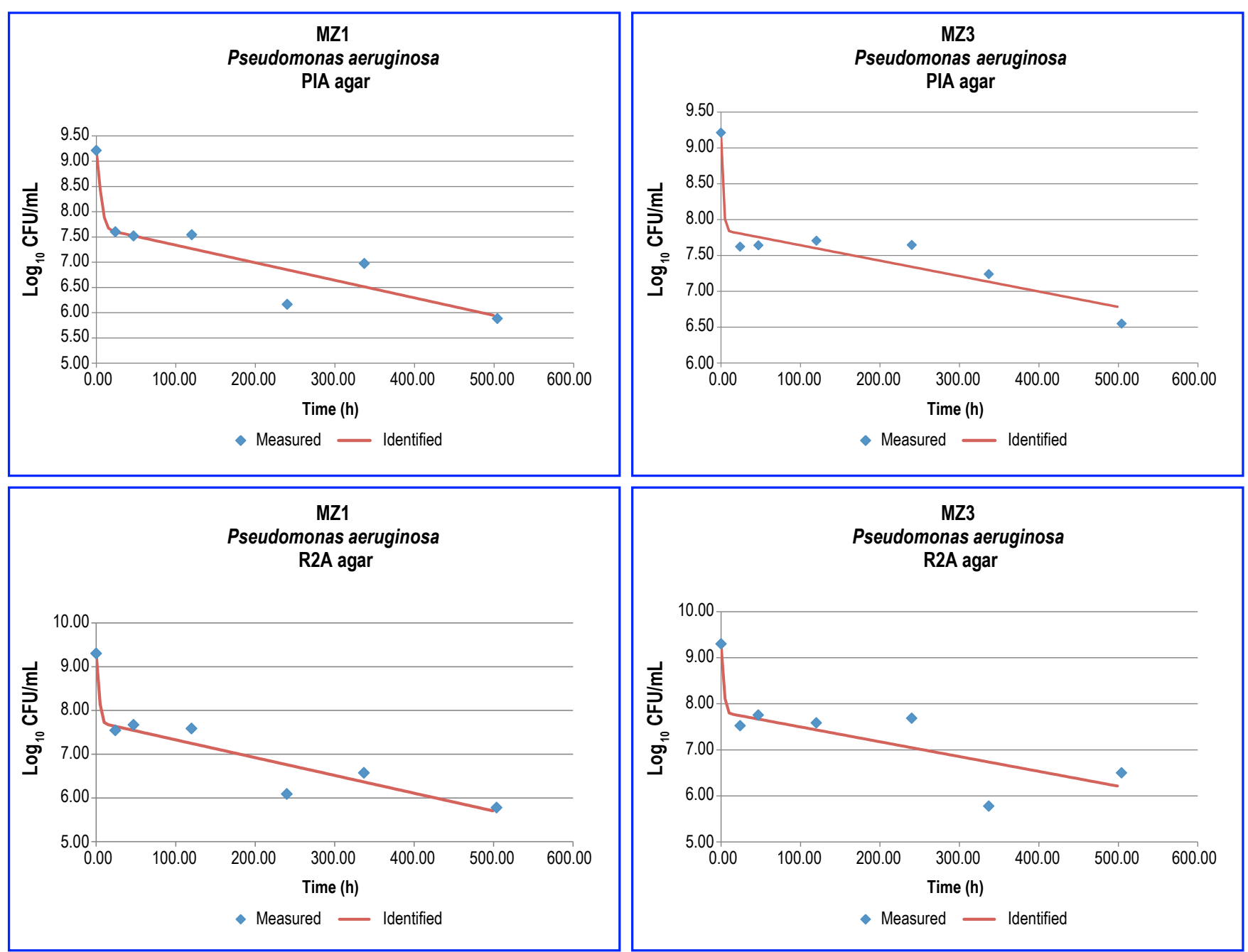

Figure 13. Graph showing Pseudomonas aeruginosa decay rates from the $M Z 1$ and $M Z 3$ sampling sites $\left[\log _{10} \mathrm{CFU} / \mathrm{mL}, \log _{10}\right.$ colony-forming units per milliliter; $h$, hours].

\section{Relevance of Escherichia coli Inactivation Rates in the Upper Floridan aquifer}

The number of published studies on inactivation rates of $E$. coli in groundwater are few (John and Rose, 2005). Of these, a small percentage describe the use of diffusion chambers, and studies that have used diffusion chambers in situ or in systems that maintain in situ conditions are rare. Table 9 lists the published studies that have specifically quantified inactivation rates of $E$. coli in groundwater. Except for the study by Sidhu and Toze (2012), these studies did not record the native groundwater geochemical conditions, nor make an effort to maintain those conditions during the inactivation experiments. In addition, all of the studies listed in table 9 used linear regression methods to derive the inactivation rates, except for John (2003), who selectively used a polynomial equation to model data with an initial increase that was followed by a decrease in culturability. A visual inspection of the graphed data presented in these publications revealed that most of the datasets were not linear throughout the entire time of the experiments, especially for the first few sampling events. Most datasets appeared to have an initial and rapid decrease in culturability, followed by a more gradual decrease that closely resembled the data from this study (figs. 8-13). 
Table 9. Escherichia coli inactivation rate data from the published literature.

$\left[\mathrm{hr}^{-1}\right.$, per hour; $\mathrm{mL}$, milliliter]

\begin{tabular}{lll}
\hline $\begin{array}{c}\text { Inactivation rate } \\
\left(\mathrm{hr}^{-1}\right)\end{array}$ & \multicolumn{1}{c}{ Experimental design } & \multicolumn{1}{c}{ Reference } \\
\hline 0.013 & Diffusion chambers in an above ground container open to air & Bitton and others (1983) \\
0.0066 & Spiked groundwater in bench top flasks & Cook and Bolster (2007) \\
$0.004-0.007$ & Spiked groundwater in bench top flasks & Davies and Davies (2010) \\
0.004 & Spiked groundwater in 50 mL tubes & Keswick and others (1982) \\
0.029 & Diffusion chambers that were placed in situ & Sidhu and Toze (2012) \\
\hline
\end{tabular}

In the Sidhu and Toze (2012) study, diffusion chambers filled with E. coli cells were inserted into the production zones of groundwater wells. Although this aspect of their study is similar to this study, the geochemistry of their groundwater systems was significantly different from that in the region of the Upper Floridan aquifer investigated in this study. For example, the aquifer in their study maintained a dissolved oxygen concentration of $2.0 \mathrm{mg} \mathrm{L}^{-1}$ and an ORP of 222 millivolts $(\mathrm{mV})$, whereas all of the groundwaters in this study are strictly anaerobic and extremely reduced (table 2 ).

It is worth noting that the doctoral dissertation by John (2003) describes a set of experiments that used water from two wells whose production zones are located in the Upper Floridan aquifer (ROMP TR7-4: lat 27.427781, long -82.489095 and PBF-3: lat 26.675833, long-80.103056). The focus of his experimental design was the influence of total dissolved solids (TDS) on the survival of microbial indicators in groundwater. The groundwater collected for these experiments was pasteurized at $70{ }^{\circ} \mathrm{C}$ for 30 minutes and stored at $4{ }^{\circ} \mathrm{C}$ until used for the bench-top microcosm (that is, open beaker) studies. Only temperature, $\mathrm{pH}$, total organic carbon, specific conductance, and TDS data were collected. No geochemical data were collected on the native or pasteurized groundwater samples prior to, during, or after each experiment. The $k_{1}$ rates from this study are orders of magnitude greater, and the $k_{2}$ rates are 1.3 to 2.6 times greater than the fastest inactivation rate of $0.007 \mathrm{~h}^{-1}$ in John (2008) , except for rates obtained for $15 \mathrm{U}$ which were similar between these studies (tables 8 and 9).

To place the $E$. coli inactivation rates in a more applied context, an example that uses data from the Hillsboro ASR pilot project's treatment facility is presented. The pumping rate for recharge water by this facility is 5 million gallons per day $\left(\mathrm{Mgal} \mathrm{d}^{-1}\right)$. This facility has detected E. coli in the recharge water at a concentration ranging from below detection $\left(<1.0 \mathrm{CFU} 100 \mathrm{~mL}^{-1}\right)$ to $65 \mathrm{CFU} 100 \mathrm{~mL}^{-1}$. At this recharge rate and maximum $E$. coli concentration, there could be $1.23 \times 10^{10} \mathrm{E}$. coli introduced into the aquifer at the completion of a 1-day recharge event. The biphasic model used to calculate the inactivation rate data in table 8 assumes that both subpopulations independently follow first order reaction kinetics, which permits the use of Chick's Law for calculating the times required for total inactivation of both subpopulations. The most familiar form of Chick's Law is as follows:

$$
\frac{N_{t}}{N_{0}}=e^{-k t},
$$

where
$N_{t}$
$N_{0}$
is the concentration (CFU per milliliter) of injected bacteria at time $t$ (hours), is the concentration (CFU per milliliter) of bacteria at the end of the recharge event, and
$k \quad$ is the inactivation rate constant (per hour). 
The variable $N_{t}$ is set at 0.9 (assuming a value of $<1.0 \mathrm{CFU}$ represents total inactivation), $N_{0}$ is adjusted for the respective subpopulations using the $f$ or $1-f$ values, and the $k_{1}$ and $k_{2}$ values (table 8 ) are used with the appropriate $N_{0}$ values. Solving for $t$ yields an estimate of the length of storage time required for the respective subpopulations of $E$. coli to be reduced to less than 1.0 CFU (table 10). The more sensitive subpopulation of $E$. coli $\left(k_{1}\right.$ data) was reduced to less than $1.0 \mathrm{CFU}$ in all the wells at a similar rate when using mTEC agar, ranging from 1.4 to 4.5 days (table 10). The same subpopulation on R2A agar was completely inactivated at a generally slower rate, ranging from 1.6 to $5.6 \mathrm{~d}$.

The more resistant subpopulations $\left(k_{2}\right.$ data) were inactivated at significantly slower rates, regardless of which medium was used. Using the mTEC agar data, this $E$. coli subpopulation was inactivated after 1.5 to 3.7 months of storage in the respective aquifer zones. The R2A agar data were generally slower than the rates calculated from the mTEC agar data, ranging from 3.1 to 9.5 months for 42U, $15 \mathrm{M}, \mathrm{MZ1}$, and MZ3, and 7.1 years for $42 \mathrm{~L}$. The outlier in the dataset is for $15 \mathrm{U}$, where a predicted $>120.6$ years of storage are required to totally inactivate the more resistant $E$. coli subpopulation to less than 1 CFU (table 10).

Bacteria that live in natural environments are considered to be under varying degrees of physiological stress that result in significant reductions or loss of culturability (Finkel and others, 2000; McDougald and others, 1998; Nystrom, 2004). The type and severity of stress is dependent upon the in situ physical and geochemical conditions of the natural systems, disinfectants (for example, oxidants, UV irradiation) in engineered systems, and culture media and incubation conditions. However, the loss of culturability does not necessarily ensure that the noncultured cells are nonviable (that is, dead). The recovery or resuscitation of stressed and previously nonculturable bacteria from aquatic systems has been demonstrated (Barer and others, 1993; Barer and Harwood, 1999; Blatchley and others, 2007; Kell and others, 1998). This nonculturable physiological state in stressed bacteria (Roszak and Colwell, 1987) has important implications when monitoring groundwater systems for the presence of bacterial indicators of fecal contamination. As shown in this study, for both bacterial strains, the geochemical conditions in the aquifer reduce the culturability of a proportion of the total bacterial populations in the diffusion chambers. Under treatment-plant operational conditions, the storage of recharged water in this region of the Upper Floridan aquifer may contribute to filtration and disinfection log reduction credits as defined by regulatory agencies.

Additional inactivation of microbial indicators because of the secondary physiological stress of culture media and incubation conditions may reduce recovery rates even further. At low concentrations

Table 10. The estimated storage time to achieve 1.0 CFU in the recovered water at the six sampling sites.

[f, decimel fraction of total bacterial counts]

\begin{tabular}{|c|c|c|c|c|c|c|c|c|c|}
\hline \multirow{2}{*}{ Bacterium } & \multirow{2}{*}{ Media } & \multirow{2}{*}{ Population } & \multirow{2}{*}{ Time } & \multicolumn{6}{|c|}{ Well designation } \\
\hline & & & & $42 \mathrm{U}$ & 42L & $15 \mathrm{U}$ & $15 \mathrm{M}$ & MZ1 & MZ3 \\
\hline \multirow[t]{4}{*}{ Escherichia coli } & mTEC & $f$ & days & 3.3 & 1.4 & 4.5 & 1.8 & 1.5 & 1.7 \\
\hline & & $1-f$ & months & 3.1 & 1.5 & 3.7 & 1.9 & 2.4 & 2.1 \\
\hline & $\mathrm{R} 2 \mathrm{~A}$ & $f$ & days & 5.3 & 5.6 & 4.8 & 5.0 & 1.6 & 3.8 \\
\hline & & $1-f$ & months & 4.1 & 84.8 & $>247.5$ & 9.5 & 3.1 & 6.7 \\
\hline \multirow[t]{4}{*}{ Pseudomonas aeruginosa } & PIA & $f$ & days & 1.2 & 1.4 & 6.7 & 6.1 & 2.5 & 1.3 \\
\hline & & $1-f$ & months & 6.4 & 6.9 & 7.9 & 5.3 & 3.4 & 5.7 \\
\hline & $\mathrm{R} 2 \mathrm{~A}$ & $f$ & days & 3.3 & 20.2 & 2.1 & 1.4 & 1.6 & 1.4 \\
\hline & & $1-f$ & months & 7.2 & 7.3 & 12.1 & 6.1 & 2.9 & 3.7 \\
\hline
\end{tabular}


of bacteria such as $E$. coli, these additional reductions in recovery rates may provide data below the regulatory maximum contaminant level, thereby promoting a false sense of confidence in the microbiological quality of the tested waters.

\section{Dissolved Organic Carbon Characterization}

The dissolved organic carbon (DOC) concentrations in the groundwater samples were similar, ranging from 1.1 to $1.9 \mathrm{mg} \mathrm{L}^{-1}$ (table 11). These data are similar in magnitude to the DOC concentrations found in the Upper Floridan aquifer (UFA) in the Miami area (Lisle, 2005), which is also considered an isolated aquifer like that sampled during this study (table 11). The fluorescence index (FI) values were also similar between groundwater samples and with the UFA sample previously cited, ranging from 1.70 to 1.77 (table 11). When compared to FI data from the Biscayne aquifer (Lisle, 2005), which is a mix of terrestrial and microbially derived carbon, and Lake Okeechobee water, where the source of DOC is predominantly terrestrial, the DOC in the groundwater sampled during this study is classified as microbially derived. These data support the contention that the aquifer zones sampled during this study are isolated from surface-water intrusion that would carry DOC from terrestrial sources.

Volatile fatty acids (VFA) (for example, acetate, lactate, propionate, and pyruvate) (table 2) are components of DOC. Most microbial cells in anaerobic and reduced aquatic ecosystems readily metabolize volatile fatty acids. The total VFA (VFA) concentrations in the respective groundwater samples ranged from 70 micrograms per liter $\left(\mu \mathrm{g} \mathrm{L}^{-1}\right)$ to $3.87 \mathrm{mg} \mathrm{L}^{-1}$ (table 2) and accounted for 7.1 to 21.5 percent of the measured DOC (table 11). The 351.8 percent value for MZ3 is due to the extremely high concentration of lactate (table 2). A simple explanation for such an elevated lactate concentration in one sample is unlikely and this could only be resolved after completing additional sampling and analyses.

In regard to carbon concentrations in recharge water, the DOC concentration in Lake

Okeechobee water is approximately 20 times higher than in any of the sampled groundwater (table 11). Any treatment process that does not remove DOC from this surface-water source, or any other source, prior to injection will introduce carbon substrates into these subsurface ecosystems at concentrations that have not been available since the initial recharge event approximately 20,000-25,000 years before present (Meyer, 1989; Plummer and Sprinkle, 2001). This sudden increase in carbon would initiate a dramatic shift of the native geochemical signature in the receiving aquifer because of biogeochemical responses of the native and introduced microbial communities.

\begin{tabular}{|c|c|c|c|}
\hline Well designation & $\begin{array}{c}\text { DOC } \\
\left(\mathrm{mg} \mathrm{mL}^{-1}\right)\end{array}$ & FI & $\begin{array}{c}\text { VFA } \\
\text { (\% of DOC) }\end{array}$ \\
\hline $42 \mathrm{U}$ & 1.1 & 1.71 & 8.6 \\
\hline $42 \mathrm{~L}$ & 1.2 & 1.70 & 5.8 \\
\hline $15 \mathrm{U}$ & 1.7 & ND & 7.1 \\
\hline $15 \mathrm{M}$ & 1.9 & ND & 13.7 \\
\hline MZ1 & 1.2 & 1.73 & 21.5 \\
\hline MZ3 & 1.1 & 1.73 & 351.8 \\
\hline Upper Floridan Aquifer (Miami) & 1.2 & 1.77 & \\
\hline Biscayne Aquifer (Miami) & 3.1 & 1.49 & \\
\hline Lake Okeechobee & 19.7 & 1.32 & \\
\hline
\end{tabular}




\section{Bacterial Utilization and Turnover of Native Carbon}

Access to, and utilization of, organic and inorganic carbon by native microbial communities that persist in ecosystems like this region of the Upper Floridan aquifer is required for maintaining viability. Because of the extended period of time since this region of the Upper Floridan aquifer has been impacted by the introduction of surface waters and photosynthetically fixed carbon, the organic carbon concentrations are very low and their source is predominantly from microbial recycling of organic carbon and autotrophic inorganic carbon fixation. A commonly found carbon substrate in anaerobic groundwater is acetate, a volatile fatty acid. Acetate was detected in all groundwater sampled during this study, making it well suited for assessing the total carbon utilization rates in the native microbial communities, which includes mineralization (production of $\mathrm{CO}_{2}$ ) and assimilation (incorporation into biomass).

Table 12 summarizes the acetate utilization rates in each of the groundwater sources sampled during this study. The respiration-associated rates are similar and lowest for 15M and MZ1 and moderately greater for $42 \mathrm{U}, 42 \mathrm{~L}$, and MZ3. The native microbial community in $15 \mathrm{U}$ had the highest utilization rate $\left(5.8\right.$ nanomoles per hour $\left.\left(\mathrm{nM} \mathrm{h}^{-1}\right)\right)$, being between 1.5 to 2 times greater than those for the other sites. The rates of incorporating acetate into the microbial biomass (range: $3.3-9.0 \mathrm{nM} \mathrm{h}^{-1}$ ) were similar to those for respiration at $42 \mathrm{~L}$ and $15 \mathrm{U}$, approximately 1.5 times greater at $42 \mathrm{U}$ and $15 \mathrm{M}$ and 2.5 times greater at MZ3. The biomass production rates being approximately equal or greater than respiration rates indicate the native microbial populations in these zones of the Upper Floridan aquifer are capable of producing low levels of new biomass (that is, cells) in the native conditions of strict anaerobiosis, extremely low redox potentials, and low carbon concentrations.

When taking the sum of the acetate respiration and production rates, the total acetate utilization and turnover rates can be calculated (table 12). The collective utilization rates (range: 6.9-12.2 nM $\mathrm{h}^{-1}$ ) for $42 \mathrm{~L}, 15 \mathrm{M}$, and MZ1 are similar and the lowest of the sampling sites, whereas the rates for $15 \mathrm{U}$ and MZ3 are highest. The acetate turnover rates, which estimate the times required to utilize all of the acetate in sampled groundwater assuming no replenishment of acetate during the time interval, range from 4.1 days (MZ3) to 12.1 days (MZ1) (table 12).

Another method of estimating bacterial production is the use of ${ }^{3} \mathrm{H}$-leucine, an amino acid. The rates of incorporation of this amino acid into cellular proteins have been correlated with carbon content in bacterial cells (Kirchman, 2001). The derivation of the relationship between incorporated leucine rates and bacterial biomass production rates is dependent on a set of empirical factors, as described previously. Biomass production, in units of carbon (nanomoles carbon per hour), can then be related to the number of bacterial cells produced per unit time using the relationship of an average carbon content per bacterial cell of 20 femtograms carbon per cell (fg C cell ${ }^{-1}$ ) (Lee and Fuhrman, 1987). The ${ }^{3} \mathrm{H}$-leucine based biomass production rates ranged from 0.03 to 0.91 nanomoles carbon per liter per hour (nM C L ${ }^{-1} \mathrm{~h}^{-1}$ ), which will support the production of between $4.25 \times 10^{5}$ to $1.31 \times 10^{7}$ cells per liter per day $\left(\mathrm{L}^{-1} \mathrm{~d}^{-1}\right)$ (table 13). These cell production rates account for only 0.06 to 3.17 percent (table 13) of the respective native cell abundances (table 7).

Bacterial growth efficiency (BGE) is the quantity of bacterial biomass produced per unit of substrate assimilated, which in this study was acetate. The substrate can be utilized at some ratio of energy production (that is, respiration) and biomass production, which varies considerably across ecosystems and their respective nutritional gradients. Traditionally, BGE is calculated using ${ }^{3} \mathrm{H}-$ leucine data for productivity and ${ }^{14} \mathrm{C}$-labelled substrate data for respiration.

The BGE values for the bacterial communities in this study ranged from 0.002 to 0.116 (table 14). Published BGE values from marine and freshwater systems range from 0.02 to 0.23 for the 
Table 12. ${ }^{14} \mathrm{C}$-acetate turnover and utilization rate data for the native bacterial community at the six sampling sites.

$\left[\mathrm{CO}_{2}\right.$, carbon dioxide; $\mathrm{V}_{\mathrm{n}}$, acetate utilization rate; $\mathrm{T}_{\mathrm{n}}$, acetate turnover rate; $\mathrm{nM} \mathrm{h}^{-1}$, nanomoles per hour; $\mathrm{d}$, days $]$

\begin{tabular}{|c|c|c|c|c|}
\hline \multirow[b]{2}{*}{ Well designation } & \multirow{2}{*}{$\begin{array}{c}\text { Respiration }\left(\mathrm{CO}_{2}\right) \\
\text { Acetate utilization rate } \\
\left(v_{n}\right) \\
\left(\mathrm{nM} \mathrm{h}^{-1}\right)\end{array}$} & \multirow{2}{*}{$\begin{array}{c}\text { Production (biomass) } \\
\text { Acetate utilization rate } \\
\left(v_{n}\right) \\
\left(\mathrm{nM} \mathrm{h}^{-1}\right)\end{array}$} & \multicolumn{2}{|c|}{ Carbon demand (respiration + production) } \\
\hline & & & $\begin{array}{l}\text { Acetate utilization rate } \\
\qquad\left(v_{n}\right) \\
\left(\mathrm{nM} \mathrm{h}^{-1}\right)\end{array}$ & $\begin{array}{l}\text { Acetate turnover rate } \\
\left(T_{n}\right) \\
(\mathrm{d})\end{array}$ \\
\hline $42 \mathrm{U}$ & 3.6 & 5.1 & 8.7 & 7.7 \\
\hline $42 \mathrm{~L}$ & 3.7 & 3.3 & 7.0 & 7.1 \\
\hline $15 \mathrm{U}$ & 5.8 & 6.2 & 12.0 & 7.0 \\
\hline $15 \mathrm{M}$ & 2.7 & 4.4 & 7.1 & 6.9 \\
\hline MZ1 & 2.1 & 4.8 & 6.9 & 12.1 \\
\hline MZ3 & 3.2 & 9.0 & 12.2 & 4.1 \\
\hline
\end{tabular}

more oligotrophic marine waters and 0.04 to 0.08 for freshwater lakes. The published BGE data provide a reference point for the data obtained in this study, but direct comparisons would be inappropriate because this region of the Upper Floridan aquifer is anaerobic, extremely reduced, and oligotrophic. Similar conditions are not represented in the published data.

The low proportion of carbon being used for biomass production in the Upper Floridan aquifer indicates the majority of the carbon substrate is being used in respiratory functions, such as energy transduction, membrane energization, active transport across membranes, cellular repair, and so forth. These basal, or maintenance, energy requirements are critical for bacteria in all ecosystems because the cells die once these energetic requirements are not satisfied. Because maintenance energy requirements do not change with growth rates or nutritional conditions, these energy requirements (that is, carbon demand) account for a significant proportion of the available energy in oligotrophic and anaerobic systems like this region of the Upper Floridan aquifer. Accordingly, growth rates (that is, biomass production) would be expected to be significantly reduced (Russell and Cook, 1995). The concept of lower BGE values indicating lower biomass production rates is supported by the calculated BP rates in this study, which represent only 0.06 to 3.17 percent of the native bacterial concentrations of the respective groundwater sources (table 13).

Collectively, the organic carbon cycling data show the native microbial communities are viable and active but have very slow rates of metabolism. The majority of the utilized organic carbon is used to maintain vital cellular functions, with a minor proportion diverted to producing new biomass. The organic carbon turnover rates, however, present a quandary in that the rates are on the order of days to

Table 13. ${ }^{3} \mathrm{H}$-leucine-based bacterial production rates at the six sampling sites.

[nM C L ${ }^{-1} \mathrm{~h}^{-1}$, nanomoles of carbon per liter per hour; cells $\mathrm{L}^{-1} \mathrm{~d}^{-1}$, cells per liter per day; \%, percent]

\begin{tabular}{cccc}
\hline Well designation & $\begin{array}{c}\text { Biomass production } \\
\left(\mathrm{nM} \mathrm{C} \mathrm{L-1}^{-1} \mathbf{h}^{-1}\right)\end{array}$ & $\begin{array}{c}\text { Bacterial cell production } \\
\left(\text { cells } \mathbf{L}^{-1} \mathbf{d}^{-1}\right)\end{array}$ & $\begin{array}{c}\text { Percent of native biomass } \\
(\%)\end{array}$ \\
\hline $42 \mathrm{U}$ & 0.19 & $2.69 \times 10^{6}$ & 0.65 \\
$42 \mathrm{~L}$ & 0.09 & $1.24 \times 10^{6}$ & 3.17 \\
$15 \mathrm{U}$ & 0.03 & $4.25 \times 10^{5}$ & 0.06 \\
$15 \mathrm{M}$ & 0.06 & $8.30 \times 10^{5}$ & 0.11 \\
$\mathrm{MZ1}$ & 0.91 & $1.31 \times 10^{7}$ & 1.64 \\
$\mathrm{MZ3}$ & 0.1 & $1.50 \times 10^{6}$ & 0.22 \\
\hline
\end{tabular}


Table 14. Bacterial growth efficiency data for the six sampling sites.

[BP, bacterial production; BR, bacterial respiration; BGE, bacterial growth efficiency; ${ }^{3} \mathrm{H}$-leucine, tritium labled leucine; ${ }^{14} \mathrm{C}$-leucine, carbon-14 labeled leucine; ng C L ${ }^{-1} \mathrm{~h}^{-1}$, nanograms of carbon per liter per hour]

\begin{tabular}{|c|c|c|c|}
\hline Well designation & $\begin{array}{c}\text { BP } \\
{ }^{3} \mathrm{H}-\text { leucine } \\
\text { ng C L-1 } h^{-1}\end{array}$ & $\begin{array}{c}\text { BR } \\
{ }^{14} \mathrm{C} \text {-acetate } \\
\text { ng C L-1 } \mathrm{h}^{-1}\end{array}$ & BGE \\
\hline $42 \mathrm{U}$ & 1.35 & 86.8 & 0.015 \\
\hline $42 \mathrm{~L}$ & 0.62 & 88.0 & 0.007 \\
\hline $15 \mathrm{U}$ & 0.21 & 139.6 & 0.002 \\
\hline $15 \mathrm{M}$ & 0.42 & 63.6 & 0.007 \\
\hline MZ1 & 6.59 & 50.4 & 0.116 \\
\hline MZ3 & 0.75 & 77.2 & 0.010 \\
\hline
\end{tabular}

weeks and additional carbon has not been transported from a source outside the Upper Floridan aquifer for over 20,000 years (Meyer, 1989; Plummer and Sprinkle, 2001). Possible explanations as to where the organic carbon originates include the following: (1) the non-acetate proportion of the DOC could be leaching from the geologic matrix of the karst aquifer; (2) lithoautotrophic bacteria are fixing inorganic carbon (for example, $\mathrm{HCO}_{3}^{-}, \mathrm{CO}_{2}$ ) into cellular biomass; and (3) upon bacterial lysis (for example, bacteriophage infection, predatory bacteria) the cellular debris becomes DOC (Mathias and others, 2003; Middelboe and Jørgensen, 2006). This cycling of organic and inorganic carbon into and from bacterial biomass has been shown to be a central process in carbon cycling in surface-water ecosystems and is commonly referred to as the microbial loop (Jiao and others, 2011).

\section{Microbial Energetics and Sustainability in the Upper Floridan Aquifer}

The previous section describes viable and physiologically active native microbial communities in all of the groundwater sampling sites. As shown by the BGE values (table 14), the majority of the carbon being metabolized by these communities is used in the production of energy for cellular processes. These dissimilatory reactions rely on the presence of a variety of extracellular electron donors and acceptors to generate this energy. As these reactions proceed and organic and inorganic substrates and terminal electron acceptors are respectively oxidized and reduced, the products of these reactions alter groundwater chemistry. The applicability of, for example, reactive transport models for predicting changes in groundwater geochemistry would therefore improve with the inclusion of variables that constrain these biogeochemical reactions and their rates.

The most direct method for characterizing biogeochemical reactions that alter groundwater chemistry is to sample the native microbial communities and determine the types and rates of reactions that members of these communities perform under in situ conditions. Unfortunately, there are several obstacles that make this approach impractical. Having culturable representative isolates of each microbial group that performs a specific biogeochemical reaction would be ideal. However, the low culturability rates of native groundwater microorganisms make this practically impossible. For example, an average $13 \mathrm{CFU} \mathrm{mL} \mathrm{m}^{-1}$ of the native microbial community were recovered from the six groundwater sites during this study using R2A agar (data not shown). This average value represents only 0.002 to 0.03 percent of the total cells counted in each groundwater source (table 7). These percent recoveries can be increased by using recovery media and incubation conditions specifically formulated and maintained to enhance the likelihood of recovery, but expected percentage recoveries would not be predicted 
to be much greater than 1.0 percent of the total population (Amann and others, 1995). Another obstacle related to culturability is the difficulty of co-culturing two or more species that must be present for the biogeochemical reactions of interest to proceed (for example, syntrophic metabolism). In addition, the slow growth and metabolic rates (tables 12-14) in anaerobic and reduced groundwater systems like this region of the Upper Floridan aquifer would require experiments to proceed for weeks-to-decades.

\section{Free Energy Yields for Energetically Favorable Biogeochemical Reactions}

One approach to circumvent the issues just described is to determine which biogeochemical reactions are most likely to proceed using thermodynamically based energetic analyses (that is, Gibbs free energy of reaction yields) and the geochemistry of the respective groundwaters. Regardless of the growth conditions (that is, high nutrients and energy in laboratory cultures versus low nutrients and extremely low energy in the Upper Floridan aquifer), the same thermodynamic principles apply. Therefore, free energy yields of microbially driven redox reactions can be applied to constrain the list of most probable biogeochemical reactions. This approach is especially applicable to low energy ecosystems like this region of the Upper Floridan aquifer, where microbial life persist close to thermodynamic equilibria.

Amend and Shock (2001) describe free energy yields for 370 reactions that have been shown to be directly or indirectly involved in microbial metabolism. Approximately 200 of these reactions were redox reactions known to be mediated by microorganisms for the acquisition of energy for cellular metabolism. The geochemical data from this study (table 2) were used to determine which subsets of these biogeochemical reactions (table 3) were applicable to the groundwater in this study. A subset of five reactions were determined to be thermodynamically feasible in this region of the Upper Floridan aquifer, using $-20 \mathrm{~kJ} \mathrm{~mol}^{-1}$ of the limiting substrate as the minimum free energy of reaction yield required to maintain cell viability. Detailed geochemical modeling was not part of this project; therefore, mineral phases are not included in the geochemical dataset. The omission of mineral phase data and incomplete sampling of gases (for example, $\mathrm{N}_{2}$ ) prevented the use of the majority of the biogeochemical reactions that rely on these data as reactants and (or) products.

Of the five favorable reactions, three reactions (reactions 1,2, 4, and 12) were favorable in all samples, whereas reaction 3 was favorable only in the 42U and MZ1 groundwater (tables 15-17). Two of these reactions ( 3 and 4 ) are methanogenic, whereas the remaining two reactions ( 1 and 2 ) represent sulfate reductions that produce sulfides as hydrogen and acetate are oxidized, respectively. As shown in table 3, both types of reactions are dependent upon hydrogen and acetate as reactants and therefore compete for common reactants. The more interesting set of reactions is hydrogenotrophic sulfate reduction (reaction 1) and methanogenesis (reaction 3). It is commonly assumed that hydrogenotrophic and acetotrophic sulfate reduction and methanogenesis are mutually exclusive, especially in systems where sulfate is not a limiting reactant as in the Upper Floridan aquifer. This is due to sulfate reducers having a higher affinity for hydrogen (Kristjansson and others, 1982; Lovley and others, 1982; Robinson and Tiedje, 1984) and acetate (Ferry and Lessner, 2008; Schonheit and others, 1982) than methanogens, thereby maintaining hydrogen and acetate concentrations at or below a minimum threshold for methanogenesis in the presence of excess sulfate.

Although methane was detected in each groundwater sample collected for this study. This apparent contradiction may be resolved if alternative substrates for methanogenesis are present in the aquifer. Recently, low-carbon-number methylated compounds (for example, methanol, methylated amines, and methylated sulfides) have been shown to be alternative reactants for methanogens while being unutilized by sulfate reducers (Liu and Whitman, 2008). The generation of methylated sulfides occur through chemical reactions between sulfides and the methyl groups within the organic matter or DOC 
(Mitterer, 2010). In regard to sources of methylamines, Mitterer and others (2001) identified the matrix of carbonate sediments as the source of methylamines because of the inclusion of biogenic proteins during formation. The region of the Upper Floridan aquifer sampled during this study is karst and contains sulfides and low concentrations of organic matter. Collectively, the conditions are present in this region of the aquifer for the noncompetitive co-occurrence of sulfate reduction and methanogenesis, and both types of reactions are energetically favorable, ranging from 52 to $64 \mathrm{~kJ} \mathrm{~mol}^{-1}$ and 30 to $42 \mathrm{~kJ} \mathrm{~mol}^{-1}$ for the sulfate reduction and methanogenic reactions, respectively (tables 15-17).

Reaction 12 describes the anaerobic oxidation of methane (AOM), for which sulfate is the terminal electron acceptor (Knittel and Boetius, 2009). AOM is driven by cooperative or syntrophic consortia of methanotrophic archaea and sulfate-reducing bacteria. This reaction currently is poorly characterized from mechanistic and phylogenetic perspectives (Caldwell and others, 2008; Thauer and Shima, 2008). The efficiency of the overall process has been measured in marine sediments, however, where it was estimated to oxidize close to 90 percent of the biogenic methane. In regard to the cycling of carbon in anaerobic, reduced, and isolated regional aquifers like this region of the Upper Floridan aquifer this is an important process even though the free energy yields are equal to, or just above, the minimum threshold of $20 \mathrm{~kJ} \mathrm{~mol}^{-1}$. AOM returns the reduced carbon back to a more oxidized state (that is, $\mathrm{HCO}_{2}^{-}$), which can then be recycled as a reactant for methanogenesis (reaction 3), acetogenesis (reaction 6), and other reactions listed in table 3.

\section{Chemical Affinities for Energetically Favorable Biogeochemical Reactions}

The direct comparison of the most likely biogeochemical reactions within and between groundwater samples is somewhat simplified by using the respective chemical affinities as opposed to free energy yields (that is, $\Delta \mathrm{G}_{\mathrm{r}}$ ). Using chemical affinities allows the ranking of biogeochemical reactions, where the values of the most likely reactions are positive and thermodynamic equilibrium is realized at a value of 0.0 (table 18). Figure 14 shows the rankings of the biogeochemical reactions from lowest-tohighest chemical affinity for each groundwater sample. The most common reactions (reactions $1-4,12$ ) are similar in all samples for the reasons discussed previously, with reaction 1 (sulfate reduction) having the greatest range of values. This alignment of sample sites based on energy yields from sulfate reduction (reaction 1), from least-to-greatest chemical affinity, follows the increasing concentrations of hydrogen (table 2). Hydrogen concentrations in the subsurface have been shown to have a central role in determining which biogeochemical processes dominate in anaerobic ecosystems, like this region of the Upper Floridan aquifer, that are controlled by bacterial energetics (that is, thermodynamics) (Hoehler and others, 1998; Hoehler and Jorgensen, 2013).

As an example of the impact that treated surface water injected into the Upper Floridan aquifer can have on native microbial community energetics, a representative geochemical dataset from recharge water from the Hillsboro pilot plant (table 2) was analyzed as the other groundwater samples for free energy yields and chemical affinities (tables 18 and 19). The most significant differences between the native and recharge water are the presence of dissolved oxygen, dissolved organic carbon, nitrate, and phosphate in the recharge water. The presence of dissolved oxygen and nitrates provide concentrations of high energy reactants for biogeochemical reactions performed by native bacteria. As can be seen in table 18, not only are additional biogeochemical reactions energetically favorable (reactions 10, 17, 19, 20, 25-27), their free energy yields are orders of magnitude greater than any of the favorable reactions in the native groundwater zones. The exclusion of reactions 1-4 and 12 from the list of favorable reactions in the recharge water, which were dominant in the native groundwater samples, reflects the general difference between the water types and the respective ecosystems: aerobic and oxidized versus 
Table 15. Free energy flux and maximum acquition rate data for the $42 \mathrm{U}$ and $42 \mathrm{~L}$ sampling sites.

$\left[\Delta \mathrm{G}_{\mathrm{r}}\right.$, free energy of the reaction; FEF, free energy flux; MAR, maximum aquitition rate; $\mathrm{kJ} \mathrm{mol}^{-1}$, kilojoules per mole; $\mathrm{kJ}$ cell- ${ }^{-1} \mathrm{~s}^{-1}$, kilojoules per cell per second; $\mu \mathrm{M} \mathrm{d}^{-1}$, micromoles per day]

\begin{tabular}{|c|c|c|c|c|c|c|c|}
\hline \multirow{2}{*}{$\begin{array}{c}\text { Equation } \\
\text { number }\end{array}$} & \multirow[b]{2}{*}{ Equation } & \multicolumn{3}{|c|}{$42 \mathrm{U}$} & \multicolumn{3}{|c|}{$42 \mathrm{~L}$} \\
\hline & & $\begin{array}{c}\Delta \mathrm{G}_{\mathrm{r}} \\
\left(\mathrm{kJ} \mathrm{mol}^{-1}\right)\end{array}$ & $\begin{array}{c}\text { FEF } \\
\left(\mathrm{kJ} \mathrm{cell}^{-1} \mathrm{~s}^{-1}\right)\end{array}$ & $\begin{array}{c}\text { MAR } \\
\left(\mu \mathrm{M} \mathrm{d}^{-1}\right)\end{array}$ & $\begin{array}{c}\Delta \mathrm{G}_{\mathrm{r}} \\
\left(\mathrm{kJ} \mathrm{mol}^{-1}\right)\end{array}$ & $\begin{array}{c}\text { FEF } \\
\left(\mathrm{kJ} \mathrm{cell}^{-1} \mathbf{s}^{-1}\right)\end{array}$ & $\begin{array}{c}\text { MAR } \\
\left(\mu \mathrm{M} \mathrm{d}^{-1}\right)\end{array}$ \\
\hline 1 & $4 \mathrm{H}_{2}+\mathrm{H}^{+}+\mathrm{SO}_{4}^{2-} \rightarrow \mathrm{HS}^{-}+4 \mathrm{H}_{2} \mathrm{O}$ & -63 & -8.3 & 4.5 & -39 & $-3.5 \times 10^{-18}$ & 3.2 \\
\hline 2 & $\mathrm{CH}_{3} \mathrm{COO}^{-}+\mathrm{SO}_{4}^{2-} \rightarrow 2 \mathrm{HCO}_{3}^{-}+\mathrm{HS}^{-}$ & -52 & -2.7 & 20.0 & -53 & $-1.8 \times 10^{-16}$ & 146.9 \\
\hline 3 & $4 \mathrm{H}_{2}+\mathrm{H}^{+}+\mathrm{HCO}_{3}^{-} \rightarrow \mathrm{CH}_{4}+3 \mathrm{H}_{2} \mathrm{O}$ & -42 & -5.7 & 4.5 & & & \\
\hline 4 & $\mathrm{CH}_{3} \mathrm{COO}^{-}+\mathrm{H}_{2} \mathrm{O} \rightarrow \mathrm{CH}_{4}+\mathrm{HCO}_{3}^{-}$ & -31 & -1.6 & 20.0 & -32 & $-1.0 \times 10^{-16}$ & 146.9 \\
\hline 12 & $\mathrm{CH}_{4}+\mathrm{SO}_{4}^{2-} \rightarrow \mathrm{H}_{2} \mathrm{O}+\mathrm{HCO}_{2}^{-}+\mathrm{HS}^{-}$ & -21 & -6.6 & 11.2 & -22 & $-5.5 \times 10^{-17}$ & 86.4 \\
\hline
\end{tabular}

Table 16. Free energy flux and maximum acquition rate data for the $15 \mathrm{U}$ and $15 \mathrm{M}$ sampling sites.

$\left[\Delta \mathrm{G}_{\mathrm{r}}\right.$, free energy of the reaction; FEF, free energy flux; MAR, maximum aquitition rate; $\mathrm{kJ} \mathrm{mol}^{-1}$, kilojoules per mole; $\mathrm{kJ}$ cell-1 $\mathrm{s}^{-1}$, kilojoules per cell per second; $\mu \mathrm{M} \mathrm{d}^{-1}$, micromoles per day]

\begin{tabular}{|c|c|c|c|c|c|c|c|}
\hline \multirow{2}{*}{$\begin{array}{l}\text { Equation } \\
\text { number }\end{array}$} & \multirow[b]{2}{*}{ Equation } & \multicolumn{3}{|c|}{$15 \mathrm{U}$} & \multicolumn{3}{|c|}{$15 \mathrm{M}$} \\
\hline & & $\begin{array}{c}\Delta G_{r} \\
\left(\mathrm{~kJ} \mathrm{~mol}^{-1}\right)\end{array}$ & $\begin{array}{c}\text { FEF } \\
\left(\mathrm{kJ} \mathrm{cell}^{-1} \mathrm{~s}^{-1}\right)\end{array}$ & $\begin{array}{c}\text { MAR } \\
\left(\mu M d^{-1}\right)\end{array}$ & $\begin{array}{c}\Delta \mathrm{G}_{\mathrm{r}} \\
\left(\mathrm{kJ} \mathrm{mol}^{-1}\right)\end{array}$ & $\begin{array}{c}\text { FEF } \\
\left(\mathrm{kJ} \mathrm{cell}^{-1} \mathrm{~s}^{-1}\right)\end{array}$ & $\begin{array}{c}\text { MAR } \\
\left(\mu \mathrm{M} \mathrm{d}^{-1}\right)\end{array}$ \\
\hline 1 & $4 \mathrm{H}_{2}+\mathrm{H}^{+}+\mathrm{SO}_{4}^{2-} \rightarrow \mathrm{HS}^{-}+4 \mathrm{H}_{2} \mathrm{O}$ & -60 & $-5.2 \times 10^{-17}$ & 54.4 & -53 & $-2.6 \times 10^{-17}$ & 31.1 \\
\hline 2 & $\mathrm{CH}_{3} \mathrm{COO}^{-}+\mathrm{SO}_{4}^{2-} \rightarrow 2 \mathrm{HCO}_{3}^{-}+\mathrm{HS}^{-}$ & -50 & $-2.9 \times 10^{-16}$ & 440.6 & -48 & $-1.6 \times 10^{-16}$ & 216.0 \\
\hline 3 & $4 \mathrm{H}_{2}+\mathrm{H}^{+}+\mathrm{HCO}_{3}^{-} \rightarrow \mathrm{CH}_{4}+3 \mathrm{H}_{2} \mathrm{O}$ & -40 & $-3.5 \times 10^{-17}$ & 54.4 & -34 & $-1.7 \times 10^{-17}$ & 31.1 \\
\hline 4 & $\mathrm{CH}_{3} \mathrm{COO}^{-}+\mathrm{H}_{2} \mathrm{O} \rightarrow \mathrm{CH}_{4}+\mathrm{HCO}_{3}^{-}$ & -30 & $-1.7 \times 10^{-16}$ & 440.6 & -28 & $-9.7 \times 10^{-17}$ & 216.0 \\
\hline 12 & $\mathrm{CH}_{4}+\mathrm{SO}_{4}^{2-} \rightarrow \mathrm{H}_{2} \mathrm{O}+\mathrm{HCO}_{2}^{-}+\mathrm{HS}^{-}$ & -20 & $-9.3 \times 10^{-17}$ & 293.8 & -20 & $-9.5 \times 10^{-17}$ & 311.0 \\
\hline
\end{tabular}

Table 17. Free energy flux and maximum acquition rate data for the MZ1 and MZ3 sampling sites.

$\left[\Delta \mathrm{G}_{\mathrm{r}}\right.$, free energy of the reaction; FEF, free energy flux; MAR, maximum aquitition rate; $\mathrm{kJ} \mathrm{mol}^{-1}$, kilojoules per mole; $\mathrm{kJ}$ cell ${ }^{-1} \mathrm{~s}^{-1}$, kilojoules per cell per second; $\mu \mathrm{M} \mathrm{d}^{-1}$, micromoles per day]

\begin{tabular}{|c|c|c|c|c|c|c|c|}
\hline \multirow{2}{*}{$\begin{array}{l}\text { Equation } \\
\text { number }\end{array}$} & \multirow[b]{2}{*}{ Equation } & \multicolumn{3}{|c|}{ MZ1 } & \multicolumn{3}{|c|}{ MZ3 } \\
\hline & & $\begin{array}{c}\Delta G_{\mathrm{r}} \\
\left(\mathrm{kJ} \mathrm{mol}^{-1}\right)\end{array}$ & $\begin{array}{c}\text { FEF } \\
\left(\mathrm{kJ} \mathrm{cell}^{-1} \mathrm{~s}^{-1}\right)\end{array}$ & $\begin{array}{c}\text { MAR } \\
\left(\mu \mathrm{M} \mathrm{d}^{-1}\right)\end{array}$ & $\begin{array}{c}\Delta G_{\mathrm{r}} \\
\left(\mathrm{kJ} \mathrm{mol}^{-1}\right)\end{array}$ & $\begin{array}{c}\text { FEF } \\
\left(k J \text { cell }^{-1} s^{-1}\right)\end{array}$ & $\begin{array}{c}\text { MAR } \\
\left(\mu M d^{-1}\right)\end{array}$ \\
\hline 1 & $4 \mathrm{H}_{2}+\mathrm{H}^{+}+\mathrm{SO}_{4}^{2-} \rightarrow \mathrm{HS}^{-}+4 \mathrm{H}_{2} \mathrm{O}$ & -64 & $-1.1 \times 10^{-16}$ & 121.0 & -26 & $-4.4 \times 10^{-19}$ & 1.1 \\
\hline 2 & $\mathrm{CH}_{3} \mathrm{COO}^{-}+\mathrm{SO}_{4}^{2-} \rightarrow 2 \mathrm{HCO}_{3}^{-}+\mathrm{HS}^{-}$ & -54 & $-3.3 \times 10^{-16}$ & 501.1 & -56 & $-1.4 \times 10^{-16}$ & 216.0 \\
\hline 3 & $4 \mathrm{H}_{2}+\mathrm{H}^{+}+\mathrm{HCO}_{3}^{-} \rightarrow \mathrm{CH}_{4}+3 \mathrm{H}_{2} \mathrm{O}$ & -40 & $-6.7 \times 10^{-17}$ & 121.0 & & & \\
\hline 4 & $\mathrm{CH}_{3} \mathrm{COO}^{-}+\mathrm{H}_{2} \mathrm{O} \rightarrow \mathrm{CH}_{4}+\mathrm{HCO}_{3}^{-}$ & -30 & $-1.8 \times 10^{-16}$ & 501.1 & -30 & $-7.8 \times 10^{-17}$ & 216.0 \\
\hline 12 & $\mathrm{CH}_{4}+\mathrm{SO}_{4}^{2-} \rightarrow \mathrm{H}_{2} \mathrm{O}+\mathrm{HCO}_{2}^{-}+\mathrm{HS}^{-}$ & -24 & $-2.3 \times 10^{-16}$ & 648.0 & -26 & $-1.2 \times 10^{-16}$ & 259.2 \\
\hline
\end{tabular}

anaerobic and reduced. When comparing the geochemical data from the groundwater samples to those from the recharge water (table 2), however, the absence of data for the dissolved gases, volatile fatty acids and inorganic carbon species in the recharge water prohibits the calculation of free energy yields and chemical affinities for most of the reactions in table 3.

Adding the chemical affinity data for the favorable biogeochemical reactions in the recharge water to those from the native groundwater samples, it is apparent the recharge water has a unique and high energy profile relative to the groundwater samples (table 18). This increase in bioavailable energy 
plus the organic carbon (table 2) greatly changes the overall energy landscape in the recharge zone of the aquifer and the rates of biogeochemical reactions that alter geochemistry. The products of the aerobic mineralization of the carbon and nutrients in the recharge water produce preferred reactants for the anaerobic native microbial community that, in addition to energy production, promote biomass production with the concomitant reduction in the ORP to native levels.

Although the recharge water may meet regulatory criteria prior to injection and after recovery, those criteria do not provide data about the biogeochemical processes that alter the geochemistry of the native and recharged water during storage. However, the thermodynamics of biogeochemical reactions does provide a tool for developing predictive models of changes in groundwater chemistry that are driven by microbial activities.

\section{Free Energy Flux Rates for Energetically Favorable Biogeochemical Reactions}

The previous section described the most likely or favorable biogeochemical reactions based strictly on their respective energy yields within the context of equaling or exceeding a minimum threshold for bacterial viability. This approach provides a framework for developing a first-order assessment of which reactants and products present in the native or recharged water may be utilized by the microbial communities, but it does not provide any insight into the rates at which these favorable reactions proceed. The free energy flux (FEF) and maximum acquisition (MAR) rates for bacterial cells constrain the energy production and reactant acquisition rates for the respective biogeochemical reactions based on the diffusion coefficient or rate (centimeters squared per second) of the limiting substrates in those reactions. These data can then be used to estimate energy acquisition, reactant utilization, and product production rates for biogeochemical reactions.

The direct relationship between diffusion and FEF and MAR rates in bacteria is due to molecular diffusion being the dominant transport mechanism for solutes and gases at distances relevant to microbial physiology (Koch, 1990). Using oxygen as an example, which is commonly reported to

Table 18. Chemical affinities for the six sampling sites and recharge water.

$\left[\mathrm{kJ} \mathrm{mol}^{-1}\right.$, kilojoules per mole]

\begin{tabular}{|c|c|c|c|c|c|c|c|c|}
\hline \multirow[b]{2}{*}{$\begin{array}{c}\text { Equation } \\
\text { number }\end{array}$} & \multirow[b]{2}{*}{ Equation } & \multicolumn{7}{|c|}{ Well designation } \\
\hline & & $\begin{array}{c}42 \mathrm{U} \\
\left(\mathrm{kJ} \mathrm{mol}^{-1}\right)\end{array}$ & $\begin{array}{c}42 \mathrm{~L} \\
\left(\mathrm{~kJ} \mathrm{~mol}^{-1}\right)\end{array}$ & $\begin{array}{c}\mathrm{MZ1} \\
\left(\mathrm{kJ} \mathrm{mol}^{-1}\right)\end{array}$ & $\begin{array}{c}\mathrm{MZ3} \\
\left(\mathrm{kJ} \mathrm{mol}^{-1}\right)\end{array}$ & $\begin{array}{c}15 \mathrm{U} \\
\left(\mathrm{kJ} \mathrm{mol}^{-1}\right)\end{array}$ & $\begin{array}{c}15 \mathrm{M} \\
\left(\mathrm{kJ} \mathrm{mol}^{-1}\right)\end{array}$ & $\begin{array}{c}\text { Recharge } \\
\text { water } \\
\left(\mathrm{kJ} \mathrm{mol}^{-1}\right)\end{array}$ \\
\hline 1 & $4 \mathrm{H}_{2}+\mathrm{H}^{+}+\mathrm{SO}_{4}^{2-} \rightarrow \mathrm{HS}^{-}+4 \mathrm{H}_{2} \mathrm{O}$ & 47.8 & 24.8 & 49.4 & 11.7 & 45.2 & 38.5 & \\
\hline 2 & $\mathrm{CH}_{3} \mathrm{COO}^{-}+\mathrm{SO}_{4}^{2-} \rightarrow 2 \mathrm{HCO}_{3}^{-}+\mathrm{HS}^{-}$ & 34.8 & 36.2 & 37.1 & 38.7 & 32.9 & 30.5 & \\
\hline 3 & $4 \mathrm{H}_{2}+\mathrm{H}^{+}+\mathrm{HCO}_{3}^{-} \rightarrow \mathrm{CH}_{4}+3 \mathrm{H}_{2} \mathrm{O}$ & 27.4 & & 25.0 & & 25.1 & 19.3 & \\
\hline 4 & $\mathrm{CH}_{3} \mathrm{COO}^{-}+\mathrm{H}_{2} \mathrm{O} \rightarrow \mathrm{CH}_{4}+\mathrm{HCO}_{3}^{-}$ & 14.1 & 14.2 & 12.8 & 12.8 & 12.8 & 11.2 & \\
\hline 10 & $\mathrm{HS}^{-}+\mathrm{NO}_{3}^{-}+\mathrm{H}_{2} \mathrm{O} \rightarrow \mathrm{SO}_{4}^{2-}+\mathrm{NH}_{3}$ & & & & & & & 406.1 \\
\hline 12 & $\mathrm{CH}_{4}+\mathrm{SO}_{4}^{2-} \rightarrow \mathrm{H}_{2} \mathrm{O}+\mathrm{HCO}_{2}^{-}+\mathrm{HS}^{-}$ & 4.1 & 4.9 & 7.5 & 8.9 & 3.0 & 3.0 & \\
\hline 17 & $\mathrm{H}_{2} \mathrm{~S}+4 \mathrm{NO}_{3}^{-} \rightarrow \mathrm{SO}_{4}^{2-}+4 \mathrm{NO}_{2}^{-}+2 \mathrm{H}^{+}$ & & & & & & & 470.3 \\
\hline 19 & $3 \mathrm{H}_{2} \mathrm{~S}+4 \mathrm{NO}_{2}^{-}+2 \mathrm{H}^{+}+4 \mathrm{H}_{2} \mathrm{O} \rightarrow 3 \mathrm{SO}_{4}^{2-}+4 \mathrm{NH}_{4}^{+}$ & & & & & & & 1239.7 \\
\hline 20 & $3 \mathrm{H}_{2}+\mathrm{NO}_{2}^{-}+2 \mathrm{H}^{+} \rightarrow \mathrm{NH}_{4}^{+}+2 \mathrm{H}_{2} \mathrm{O}$ & & & & & & & 350.0 \\
\hline 25 & $\mathrm{NH}_{3}+1.5 \mathrm{O}_{2} \rightarrow \mathrm{NO}_{2}^{-}+\mathrm{H}^{+}+\mathrm{H}_{2} \mathrm{O}$ & & & & & & & 287.9 \\
\hline 26 & $2 \mathrm{NO}_{2}^{-}+\mathrm{O}_{2} \rightarrow 2 \mathrm{NO}_{3}^{-}$ & & & & & & & 142.3 \\
\hline 27 & $\mathrm{HS}^{-}+2 \mathrm{O}_{2}+\mathrm{H}_{2} \mathrm{O} \rightarrow \mathrm{SO}_{4}^{2-}+\mathrm{H}^{+}$ & & & & & & & 790.8 \\
\hline
\end{tabular}




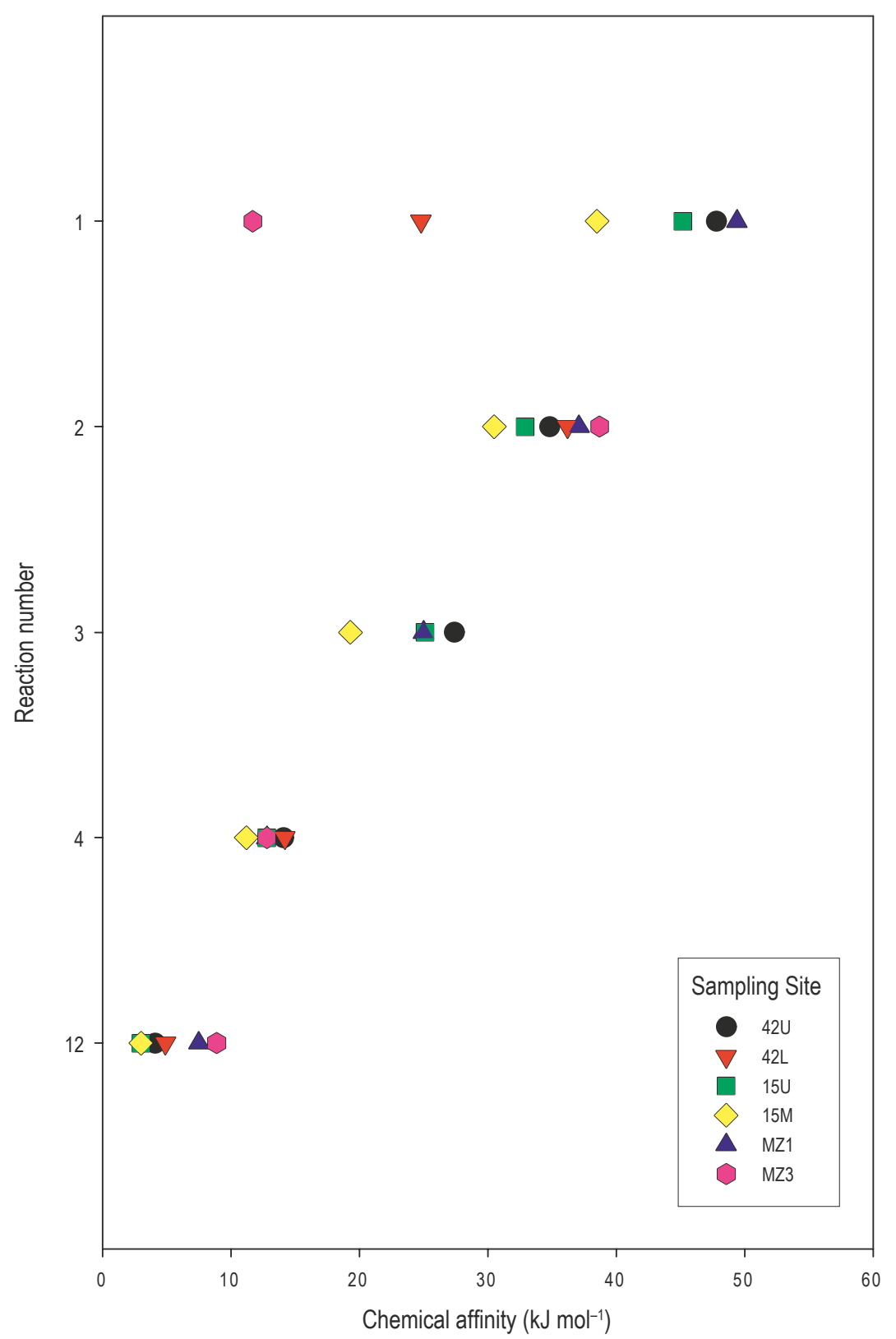

Figure 14. Graph showing chemical affinities of the thermodynamically favorable biogeochemical reactions [kJ mol-1, kilojoules per mole].

diffuse at 1.0 millimeters per hour $\left(\mathrm{mm} \mathrm{h}^{-1}\right)$, it would require approximately 1 day to diffuse $2.0 \mathrm{~cm}$ and 1,000 years to reach 10 meters $(\mathrm{m})$ from its source. At the micrometer scale, however, which is relevant for bacterial processes at the intra- and extracellular levels, this same source of oxygen requires only $10^{-3}$ seconds to diffuse $1.0 \mu \mathrm{m}$. Gases and dissolved organic and inorganic substrates that serve as reactants in this study are predominantly transported across bacterial membranes by diffusion. Assuming that (1) each of the limiting reactants in the energetically favorable biogeochemical reactions are dissolved and present at the cell surfaces at the detected concentrations in the groundwater samples, and that (2) diffusion is the mechanism by which the reactants are transported into the cell, the overall FEF and MAR rates are controlled by the respective diffusion rates. 
Table 19. Free energy flux and maximum acquition rate data for the recharge water.

$\left[\Delta \mathrm{G}_{\mathrm{r}}\right.$, free energy of the reaction; $\mathrm{kJ} \mathrm{mol}^{-1}$, kilojoules per mole]

\begin{tabular}{|c|c|c|}
\hline $\begin{array}{l}\text { Equation } \\
\text { number }\end{array}$ & Equation & $\begin{array}{c}\text { Recharge water } \\
\Delta \mathbf{G}_{\mathrm{r}} \\
\left(\mathrm{kJ} \mathrm{mol}^{-1}\right)\end{array}$ \\
\hline 10 & $\mathrm{HS}^{-}+\mathrm{NO}_{3}^{-}+\mathrm{H}_{2} \mathrm{O} \rightarrow \mathrm{SO}_{4}^{2-}+\mathrm{NH}_{3}$ & -423 \\
\hline 17 & $\mathrm{H}_{2} \mathrm{~S}+4 \mathrm{NO}_{3}^{-} \rightarrow \mathrm{SO}_{4}^{2-}+4 \mathrm{NO}_{2}^{-}+2 \mathrm{H}^{+}$ & -488 \\
\hline 19 & $3 \mathrm{H}_{2} \mathrm{~S}+4 \mathrm{NO}_{2}^{-}+2 \mathrm{H}^{+}+4 \mathrm{H}_{2} \mathrm{O} \rightarrow 3 \mathrm{SO}_{4}^{2-}+4 \mathrm{NH}_{4}^{+}$ & -1257 \\
\hline 25 & $\mathrm{NH}_{3}+1.5 \mathrm{O}_{2} \rightarrow \mathrm{NO}_{2}^{-}+\mathrm{H}^{+}+\mathrm{H}_{2} \mathrm{O}$ & -305 \\
\hline 26 & $2 \mathrm{NO}_{2}^{-}+\mathrm{O}_{2} \rightarrow 2 \mathrm{NO}_{3}^{-}$ & -159 \\
\hline 27 & $\mathrm{HS}^{-}+2 \mathrm{O}_{2}+\mathrm{H}_{2} \mathrm{O} \rightarrow \mathrm{SO}_{4}^{2-}+\mathrm{H}^{+}$ & -808 \\
\hline
\end{tabular}

The FEF rates for the energetically favorable biogeochemical reactions in the groundwater samples from this study are extremely low, ranging from $-4.4 \times 10^{-19}$ to $-3.3 \times 10^{-16}$ kilojoules per second per cell $\left(\mathrm{kJ} \mathrm{s}^{-1}\right.$ cell $\left.{ }^{-1}\right)$ (tables 15-17). This range of FEF rates are similar to those in deep subsurface ecosystems that are strictly chemolithotrophic and supported by hydrogeothermal processes (Lin and others, 2006). For the FEF rates to be relevant to the survival of the bacterial cell, the acquired energy must at least satisfy the basal or minimal energy requirements for performing bacterial cell maintenance and repair processes. An average maintenance energy per cell rate of $-1.55 \times 10^{-19}$ kilojoules per cell per second $\left(\mathrm{kJ} \mathrm{cell}^{-1} \mathrm{~s}^{-1}\right)$ has been estimated from chemostat studies of mesophilic nitrifying and methanogenic bacteria (Onstott, 2005). All of the FEF values for the energetically favorable biogeochemical reactions in this study exceed this maintenance energy threshold by approximately threefold to several orders of magnitude.

The FEF data are estimates of rates for energy acquisition per bacterial cell. The MAR data provide estimates of the acquisition rates of the limiting reactant per bacterial abundance and, therefore, can also provide an estimate of product production rates from stoichiometrically balanced reactions. The MAR data for all of the energetically favorable reactions in this study range from 1.1 to 648 micromoles per day $\left(\mu \mathrm{M} \mathrm{d}^{-1}\right)$ for the respective limiting reactants (tables 15-17). As an example of using MAR data for determining reaction rates, acetate in reaction 2 for $42 \mathrm{U}$ is the limiting reactant with an MAR of $20.0 \mu \mathrm{M} \mathrm{d}^{-1}$; therefore, a production rate of $40.0 \mu \mathrm{M} \mathrm{day}^{-1}$ for $\mathrm{HCO}_{3}^{-}$and $20.0 \mu \mathrm{M} \mathrm{d}^{-1}$ for $\mathrm{HS}^{-}$would be predicted.

The relationships between free energy yields, FEF, and MAR for the groundwater zones are shown in figure 15. The horizontal axis indicates the free energy yield, from the least-to-greatest absolute values, for all of the favorable biogeochemical reactions. Anaerobic methane oxidation (reaction 12) and acetotrophic methanogenesis (reaction 4) group reasonably well at the lower free energy yields, whereas the other types of sulfate reduction (reactions 1 and 2) and methanogenesis (reaction 3) are more evenly distributed along the remaining range of free energy yield data. Although the there is a continual increase in the free energy yield data, the rates at which the bacterial cells generate energy for cellular processes (that is, FEF) follow an undulating pattern (fig. 15). The variability in the FEF data is due to the differences in concentrations of the limiting reactants, diffusion rates of those reactants, and the calculated free energy yields at the respective sampling sites. The differences between the free energy yield and FEF data indicate biogeochemical processes are most likely under the control of physical (for example, utilization rates of biogeochemical reactants and products) rather than strictly thermodynamic processes. 
The MAR data, which are energy acquisition per cell data $\left(\mathrm{kJ} \mathrm{s}^{-1}\right.$ cell $\left.{ }^{-1}\right)$ normalized to the total cell abundances in the respective groundwater samples, follow a trend similar to that of the FEF data (fig. 16). MAR data can be used to constrain the rate at which the limiting substrate in a biogeochemical reaction is utilized by the bacterial community in a volume of groundwater. To place the MAR data in a more relevant context to native conditions in this region of the Upper Floridan aquifer, the combined (that is, respiration+biomass production) ${ }^{14} \mathrm{C}$-acetate utilization rate data (table 12) can be compared to the MAR data (table 15-17). The calculated MAR rates are between two and four orders of magnitude greater than those measured using the ${ }^{14} \mathrm{C}$-acetate method (table 20). This significant discrepancy between methods for quantifying the utilization rates for acetate, and therefore product production rates, under native conditions can be partially resolved by acknowledging that 100 percent of the enumerated bacterial cells (table 7) are not acetotrophic sulfate reducers or methanogens. To estimate the number of bacterial cells in each of the groundwater samples that were potentially acetotrophic sulfate reducers and methanogens $\left(B_{\text {acetotrophic }}\right)$, the following relationship was used:

$$
B_{\text {acetotrophic }}=\frac{(T D C)\left({ }^{14} C-\text { acetate }\right)}{M A R},
$$

where data for $T D C$ (cells per liter) and ${ }^{14} C$-acetate (moles per day) and $M A R$ (moles per day) were taken from tables 7,12 , and $15-17$, respectively. Based on this relationship, between $1.33 \times 10^{5}$ and $4.59 \times 10^{5}$ cells $\mathrm{L}^{-1}$ ( or $<0.5$ percent of the total bacterial cell abundances in table 7 ) would be required to be active acetotrophic sulfate reducers and methanogens in the native groundwater samples for the calculated MAR data to model the measured ${ }^{14} \mathrm{C}$-acetate uptake rates.

Although acetate was detected in all of the groundwater samples and this carbon source was used in the example above for estimating reactant removal and product production for a specific set of biogeochemical reactions, the native source of the acetate could not be determined. There are several acetotrophic reactions that would be expected to occur in this type of ecosystem, but none of these reactions were energetically favorable and, therefore, were not included in the data analyses. The inability to identify a thermodynamically favorable acetogenic reaction is most likely the result of an inadequate geochemistry dataset for the respective groundwater samples. The collection of a more extensive set of geochemical variables (for example, gases, carbon substrates, sulfur-based compounds, and mineral phases) that includes reactants and products for a wider selection of biogeochemical reactions, such as acetogenesis, would be very beneficial.

Another example to support the collection of a more extensive geochemical data set for native, recharged, and recovered waters is that in anaerobic, extremely reduced, and chemolithotrophic systems like this region of the Upper Floridan aquifer, fermentation reactions are very important. Fermentation of various substrates is carried out by a wide variety of bacterial groups and is most probably the driver of carbon and nutrient cycling in this type of ecosystem. Figure 16 shows how fermentation supplies the reactants for chemoautotrophic and chemoheterotrophic reactions (Megonigal and others, 2003). The source of the reactants and products for these reactions are derived from the initial degradation of polymers of biological origin to monomers, which are then fermented, producing the reactants for the biogeochemical reactions like those described in this study.

The source of the polymers that the exoenzymes degrade to monomers is also unknown for this region of the Upper Floridan aquifer. The source must be autochthonous because this region of the aquifer has been isolated from terrestrial input of water containing these types of substrates for thousands of years. A possible source could be leachate from the karst matrix, as described for the noncompetitive substrates for methanogens. Another source could be the native bacterial biomass, which is lyzed by 


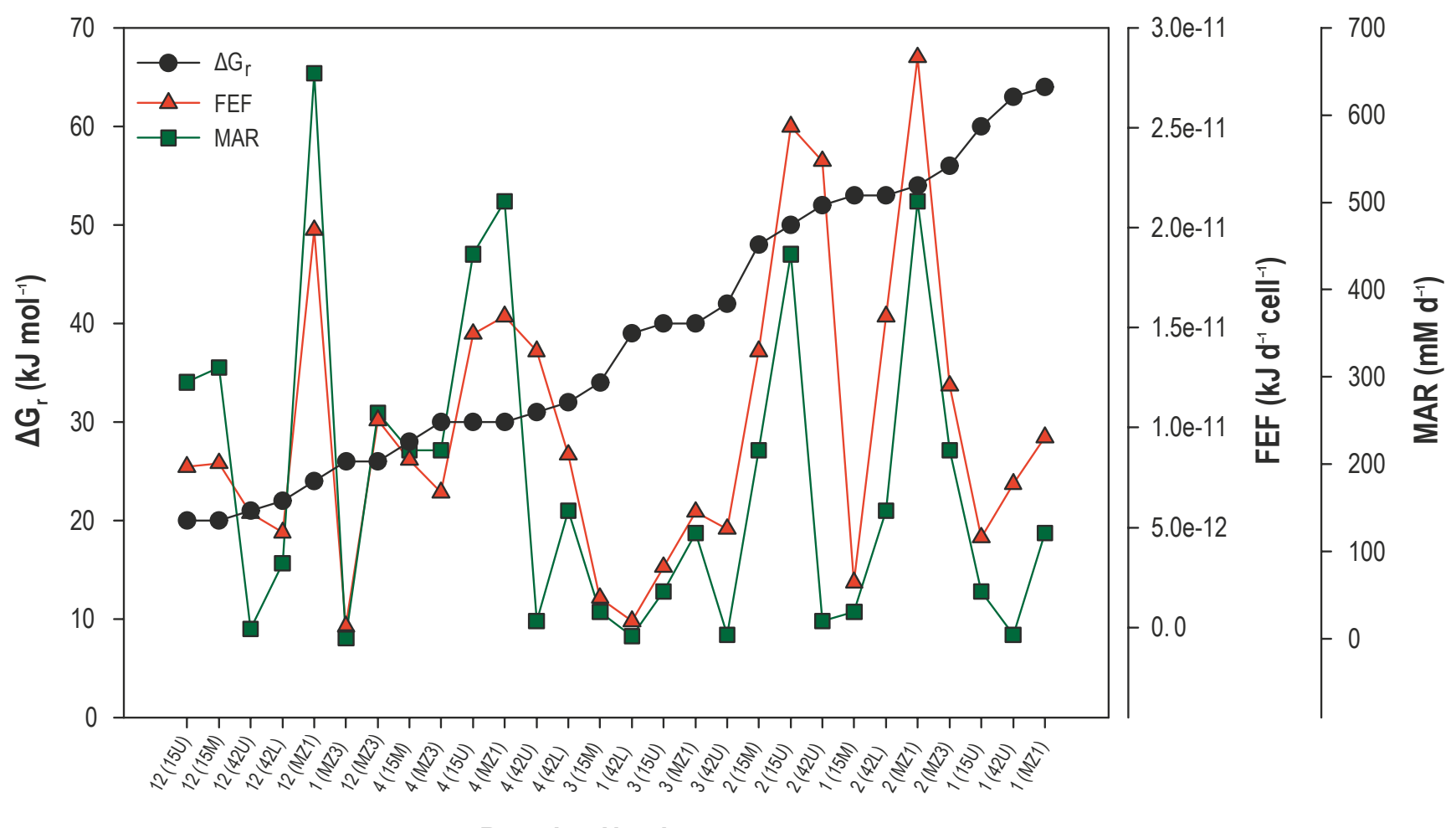

\section{Reaction Number}

Figure 15. Comparisons between the free energy of reaction $\left(\Delta G_{r}\right)$, free energy flux (FEF), and maximum acquisition rate (MAR) data from the six sampling sites [ $\mathrm{KJ} \mathrm{mol}^{-1}$, kilojoules per mole; $\mathrm{kJ} \mathrm{d}^{-1}$ celll$^{-1}$, kilojoules per day per cell; $\mathrm{mM} \mathrm{d}^{-1}$, millimoles per day].

bacteriophage, releasing complex polymers as dissolved organic carbon that can be readily assimilated by the remaining bacterial cells (Anderson and others, 2013; Noble and Fuhrman, 1999). Either or both of these sources would provide the substrates for fermentation that subsequently produces acetate directly or the reactants for acetogenesis. This simple carbon and energetic cycling model describes a closed system that exists at the boundary of thermodynamic equilibrium but could be sustainable on geologic time scales.

Although this region of the Upper Floridan aquifer is an extreme ecosystem and isolated from terrestrial carbon and nutrient inputs, the native bacteria have sources of energy that support their survival and persistence. The use of thermodynamics to describe and quantify the energetics of this ecosystem provide a framework to constrain the effects that microbial activities have on the geochemical quality of the native groundwater, the recharged and mixed water, and the rates at which those changes proceed. The inclusion of physical principles that directly influence these activities (that is, diffusion rates of limiting reactants) allows biogeochemical data like MAR to be used in the modeling of changes to groundwater chemistry over time and distance. Using biogeochemical data derived from the same groundwater system being modeled is a preferable alternative to the common practice of using laboratory-generated data that may not be truly relevant to the native groundwater conditions being modeled. 


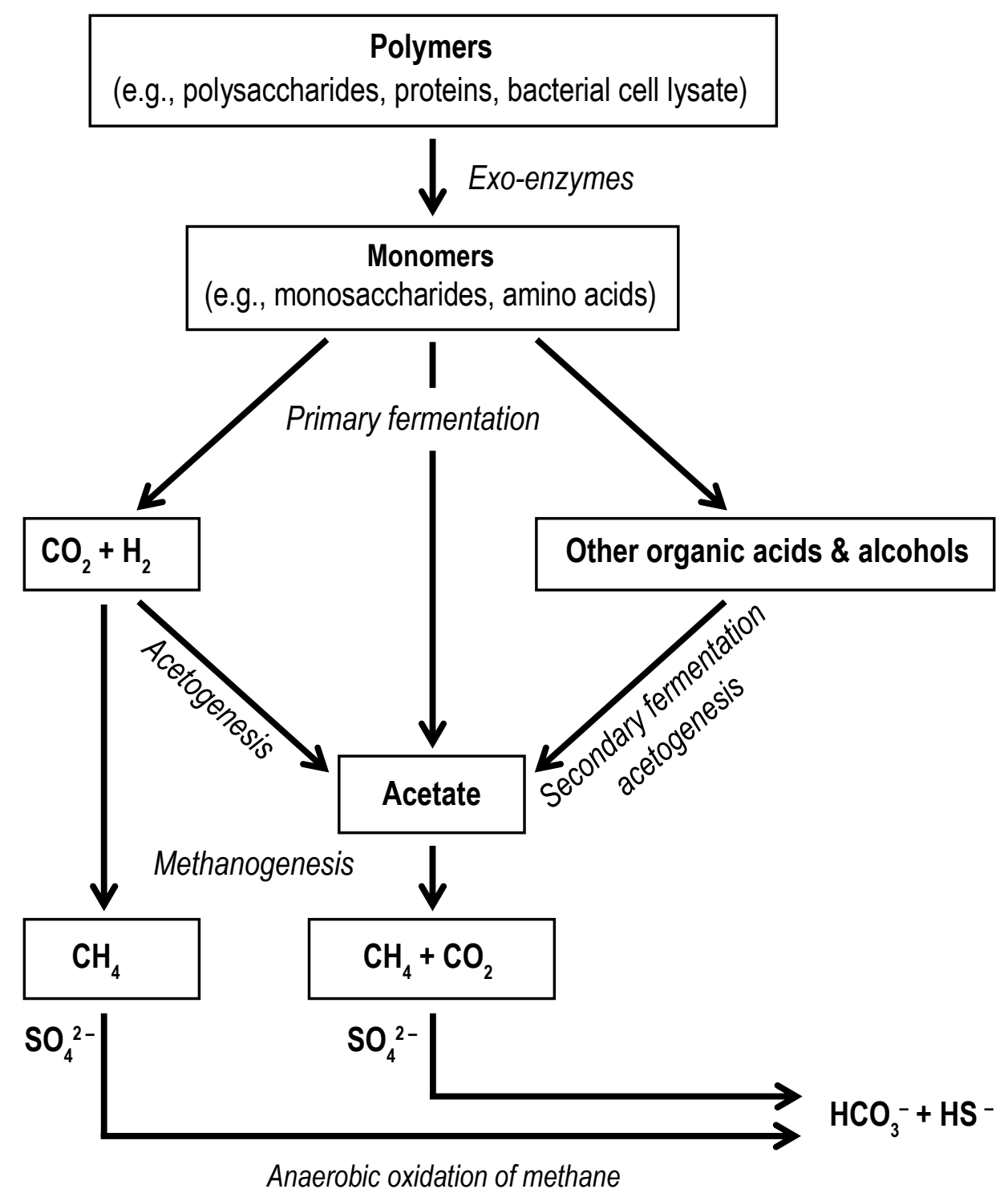

Figure 16. Biogeochemical processes that most likely dominate in the south region of the Upper Floridan aquifer.

\section{Functional Bacterial Diversity and the Relationship to Geochemistry in the Upper Floridan Aquifer}

Using thermodynamics to constrain which biogeochemical reactions, and their respective rates, are most likely to occur in the native waters of the Upper Floridan aquifer and recharge water provides a framework that can be used to supplement groundwater chemistry and reactive transport models. This approach can be applied to native groundwater prior to recharge events, recharged water prior to and during storage, and both types of water following extraction. One of the limitations to this approach is the lack of a comprehensive geochemical dataset from which the energetic calculations are performed. As previously discussed, a proportion of the complete list of biogeochemical reactions that may have been likely to proceed under the conditions of this region of the Upper Floridan aquifer could not be included in the energetics analyses because of the absence of concentration data for specific reactants and (or) products. 
Table 20. Comparisons between the measured and predicted acetate turnover rates in the six sampling sites.

\begin{tabular}{cccc}
{$\left[\begin{array}{l}{ }^{14} \mathrm{C} \text {-acetate, carbon-14 labeled acetate; MAR, maximum acquistion rate; mol d } \\
\text { Well designation }\end{array}\right.$} & $\begin{array}{c}\text { Combined }{ }^{14} \mathrm{C} \text {-acetate utilization rate } \\
\left(\mathrm{mol} \mathrm{d}^{-1}\right)\end{array}$ & $\begin{array}{c}\text { MAR } \\
\left(\mathrm{mol} \mathrm{d}^{-1}\right)\end{array}$ & MAR: ${ }^{14} \mathrm{C}$-acetate ratio \\
\hline $42 \mathrm{U}$ & $2.08 \times 10^{-7}$ & $4.00 \times 10^{-5}$ & 192.3 \\
$42 \mathrm{~L}$ & $1.68 \times 10^{-7}$ & $2.94 \times 10^{-4}$ & 1750.0 \\
$15 \mathrm{U}$ & $2.89 \times 10^{-7}$ & $8.81 \times 10^{-4}$ & 3048.4 \\
$15 \mathrm{M}$ & $1.70 \times 10^{-7}$ & $4.32 \times 10^{-4}$ & 2541.2 \\
$\mathrm{MZ1}$ & $1.66 \times 10^{-7}$ & $1.00 \times 10^{-3}$ & 6024.1 \\
$\mathrm{MZ3}$ & $2.92 \times 10^{-7}$ & $4.32 \times 10^{-4}$ & 1479.5 \\
\hline
\end{tabular}

Another approach to characterizing the native and altered geochemistry in aquifers is to characterize the native microbial diversities and changes in those diversities, respectively. Although this phylogenetic approach will not contribute to the microbial energetics and reaction rates data, knowing which types of bacteria inhabit the aquifers can provide insight into the likelihood of specific biogeochemical processes being present in the absence of geochemical data. These types of data provide insight into the physiological capacity of microbial communities to perform these biogeochemical processes.

Some biogeochemical processes are performed by a relatively limited number of bacterial species, which if detected, allow the prediction of those reactions being present in the sampled ecosystem. Examples of these types of reactions that could proceed in anaerobic conditions like those in this region of the Upper Floridan aquifer include, but are not limited to, sulfate reduction, methanogenesis, anaerobic methane oxidation (AOM), acetogenesis, anaerobic ammonium oxidation (ANAMMOX) and other pathways in the nitrogen cycle (that is, denitrification and ammonification).

The PhyloChip G3 microarray platform was used to identify the bacterial inhabitants of this region of the Upper Floridan aquifer that have been shown to perform one or more of the previously described biogeochemical processes. This technology uses a proprietary DNA sequence binding and detection approach to identify approximately 60,000 unique operational taxonomic units (OTU), representing approximately 840 subfamilies of bacteria within the Eubacteria and Archaea kingdoms. Approximately 76 percent of the OTUs from the native bacteria in this region of the Upper Floridan aquifer were categorized as "unclassified," however, meaning the sequence could not be definitively classified to the family, genus, or species level.

A total of 3,634 unique OTUs were detected in the groundwater samples from the six well sites (table 21), representing approximately 6.1 percent of the total OTUs on this version of the PhyloChip microarray. The bacterial diversity, used here and henceforth to collectively refer to eubacterial and archaeal OTUs, was similar between the two sampled depths for the 42 and 15 wells but significantly different at the $M Z$ well site, with MZ3 having a more diverse community structure than that in MZ1 (table 21). The MZ3 zone of the Upper Floridan aquifer has been shown to be the more different groundwater source of the six that were sampled, based on previously discussed field, nutrient, geochemical, and energetics data.

The number of OTUs for the second sampling event increased significantly relative to the first sampling event, except for MZ3, which decreased (table 21). For all the groundwater samples, the number of OTUs that were common in the two samples was less than the number unique to the individual samples. For example, the 42U samples had a total of 647 OTUs, of which 86 were unique to the first sample,424 were unique to the second sample, and 132 were found in both samples; 2,987 OTUs were 
not detected in $42 \mathrm{U}$ but were detected in one or more of the other groundwater samples. These same relationships are similar for the other five sites as well. The Sorensen Index values in table 21 provide a direct method for comparing the similarities in bacterial diversity between groundwater sampling sites. The proximity of index values are positively related to the similarity of their diversities. Results of the adonis test for statistically significant differences between pairwise comparisons of the OTU presence/ absence data indicated a significant difference in diversity between the six groundwater collection zones.

Using OTUs to characterize bacterial diversities provides an overall perspective of how many unique bacterial species are present; however, knowing which bacteria are represented by those OTUs allows a more detailed assessment of not only the overall diversity of the respective microbial communities but also the possible physiological capabilities. The PhyloChip data also include a single, most likely bacterial "species" associated with each OTU. "Species" is used as a general term to describe the closest (that is, 90-percent similar) identified bacterial DNA sequence in the National Center for Biotechnology Information (NCBI) database (http://www.ncbi.nlm.nih.gov). These OTU and NCBI sequence relationships can range from the family-to-species level of specificity. Figure 17 shows the OTUs from each groundwater sample organized per their proportion of the total OTUs per sample using family classifications. All of the groups in figure 17 are phylogenetic families except for Thermoprotei (class designation) and SAGMEG (South Africa Gold Mine Euarchaeotic Group) which is a nonphylogenetic grouping. Family-level classifications are used because using OTU designations from higher levels of phylogenetic classification (that is, genus and species) would significantly increase the number of graphed groups per sample, making figure 17 uninterpretable, whereas lower-level classifications do not provide adequate resolution between phylogenetic classes.

The second samples from each sampling site (denoted by "(2)") all show a significant increase in the proportion of Pseudomonadaceae (Garrity and others, 2005) (fig. 17). The other eight OTU classifications show a general decrease in their proportional contribution to each sample's diversity for the second sample. Table 22 lists the proportion that each of the nine families contributed to the groundwater samples, as shown in figure 17. The proportions of Pseudomonadaceae increased by between approximately 14 percent (42U) and 94 percent (MZ1) in the second samples. Table 22 also shows the proportion of the other families decreased between 1 and 20 percent for all sampling sites between the first and second samples, with the proportions of Peptostreptococcaceae (Schleifer, 2009) and Lachnospiraceae/ Runinococcaceae (Schleifer, 2009) in MZ1 decreasing approximately 30 percent. Unlike the other sampling sites, the proportions of OTUs in 42U representing six of the nine families increased, although marginally. The Micrococcinea (Goodfellow, 2012) in 42U were not detected in the first sample but

Table 21. Bacterial diversity in the six sampling sites and between sampling events.

[OTUs, operational taxonomic units]

\begin{tabular}{cccccc}
\hline \multirow{2}{*}{ Well designation } & \multicolumn{5}{c}{ OTUs } \\
\cline { 2 - 5 } & $\begin{array}{c}\text { Unique to } \\
\text { Sample 1 }\end{array}$ & $\begin{array}{c}\text { Unique to } \\
\text { Sample 2 }\end{array}$ & $\begin{array}{c}\text { Both } \\
\text { Samples }\end{array}$ & $\begin{array}{c}\text { Neither } \\
\text { Sample }\end{array}$ & Sorensen Index \\
\hline $42 \mathrm{U}$ & 86 & 429 & 132 & 2987 & 0.51 \\
$42 \mathrm{~L}$ & 86 & 1047 & 118 & 2383 & 0.21 \\
& 232 & 837 & 242 & 2323 & 0.45 \\
$15 \mathrm{U}$ & 215 & 1252 & 111 & 2056 & 0.15 \\
$15 \mathrm{M}$ & 478 & 1001 & 75 & 2080 & 0.10 \\
& 607 & 187 & 309 & 2531 & 0.78 \\
\hline
\end{tabular}


became a minor contributor to the community diversity in the second sample, whereas this family was never detected in 42L. Members of the Prevotellaceae (Krieg and others, 2010) followed a similar trend in $15 \mathrm{U}, 15 \mathrm{~L}, \mathrm{MZ1}$, and MZ3 by becoming nondetectable in the second sample.

The significant change in the bacterial diversity between the first and second sampling events cannot be explained by the introduction of new biomass and nutrients from a surface or near-surface source into this hydrologically isolated region of the Upper Floridan aquifer. The only perturbation to this ecosystem was the relatively rapid movement of groundwater in the production zones during the flushing of each well prior to sample collection. The suspended bacterial cells would be removed from the aquifer, whereas the biofilm-associated cells would either remain or be sloughed off because of the increased hydrodynamic shear forces at the biofilm surfaces.

As discussed previously, the groundwater flow rates are low enough in this region of the Upper Floridan aquifer to make molecular diffusion the dominant transport process for dissolved constituents. The increased groundwater flow rates during the first sampling event would transport reactants for, and remove inhibitory products of, the biogeochemical reactions previously described at rates orders of magnitude higher than those under native conditions. This sudden increase in the availability of substrates for dissimilatory and biomass production reactions would favor those bacterial species best adapted to respond quickly and efficiently. The selective increase in bacterial groups that can successfully compete for the reactants and (or) products of the biogeochemical reactions will numerically dominate until the ecosystem returns to its native state. During this period, new biogeochemical processes do not necessarily have to occur, because existing processes could just proceed at different rates. The latter is most likely to have occurred in this region of the Upper Floridan aquifer because of its geochemistry and hydrologic isolation. The response of the bacterial community to ecosystem perturbations like that described here has been described for freshwater and marine ecosystems and can be divided into three phases: bacterial community resistance, resilience, and recovery (Allison and Martiny, 2008; Ho and others, 2011; Shade and others, 2011; Sjostrom and others, 2012). This may explain the significant increases in the abundances of OTUs for Pseudomonas species (family Pseudomonadaceae; fig. 17) (table 22), which have been shown to be the most physiologically diverse and adaptable group of bacteria in terrestrial and aquatic ecosystems (Spiers and others, 2000).

The microbial diversity data also provide a framework from which a general, but sometimes specific, assignment of physiological capabilities to specific groups within the total microbial community. Figure 16 outlines a basic energy-flow carbon-cycle model that most likely describes how microbial life is supported, and figure 17 lists the dominant bacterial groups in this region of the Upper Floridan aquifer. The biogeochemical processes and microbial diversity data can be coordinated by aligning the biogeochemical processes (fig. 16) with the bacterial groups identified in the groundwater samples (fig. 17). Table 23 lists the biogeochemical processes in figure 16, plus several biogeochemical processes for which OTUs were detected but not represented in figure 17. The additional OTU classifications include Clostridiaceae (family) (Schleifer, 2009), Planctomycetes (phylum) (Ward, 2010), Euryarchaeota (phylum) (Garrity and Holt, 2001a) and Geobacteraceae (family) (Kuever and others, 2005). The additional biogeochemical processes or physiological classes include syntrophy with methanogens and ammonification. These OTU classifications and biogeochemical processes were added because OTUs were identified whose corresponding bacterial species or group had been shown to perform one or more biogeochemical processes that are not included in figure 16 but would be important to the overall carbon cycling, energetics, and geochemistry of this ecosystem.

Because of the limited geochemical analyses, determining the presence of fermentative processes in this aquifer system could not be supported, nor refuted, using the energetics approach. However, 


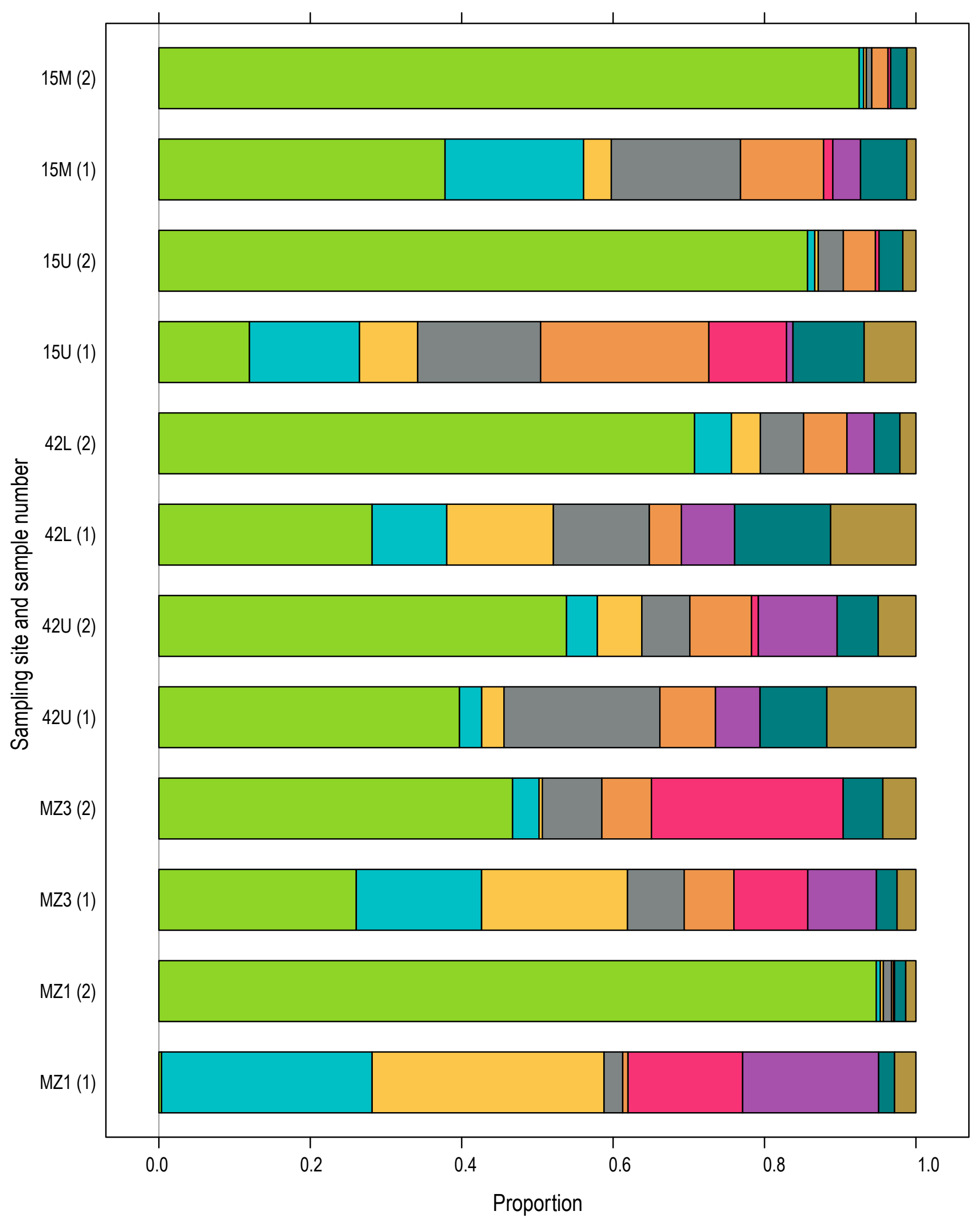

Figure 17. Bacterial diversity distributions from the six sampling sites. 


\begin{tabular}{lllll}
\hline \multicolumn{1}{c}{ Domain } & \multicolumn{1}{c}{ Phylum } & \multicolumn{1}{c}{ Class } & Order & Family \\
\hline \hline Bacteria & Proteobacteria & Gammaproteobacteria & Pseudomonadales & Pseudomonadaceae \\
Bacteria & Firmicutes & Clostridia & Clostridiales & Peptostreptococcaceae \\
Bacteria & Firmicutes & Clostridia & Clostridiales & Lachnospiraceae / Ruminococcaceae \\
Bacteria & Chloroflexi & Anaerolineae & Anaerolineales & Anaerolineaceae \\
Bacteria & Proteobacteria & Deltaproteobacteria & Desulfobacterales & Desulfobacteraceae \\
Bacteria & Actinobacteria & Actinobacteria & Actinomycetales & Micrococcineae \\
Bacteria & Bacteroidetes & Bacteroidia & Bacteroidales & Prevotellaceae \\
Archaea & Crenarchaeota & Thermoprotei & unclassified & unclassified \\
Archaea & Euryarchaeota & Thermoplasmata & SAGMEG & unclassified
\end{tabular}

Figure 17. Bacterial diversity distributions from the six sampling sites.-Continued.

the presence of bacteria capable of performing primary and secondary fermentations being in this region of the Upper Floridan aquifer is critical to explaining the concentrations of acetate in all of the groundwater samples. Acetogenesis was not energetically favorable and homoacetogens were not detected in the microbial diversity analyses. However, all but one of the OTU classifications represent one or more bacterial species that produce extracellular enzymes that degrade complex polymers into monomers that primary fermenters can utilize to produce acetate, $\mathrm{CO}_{2}, \mathrm{H}_{2}$ and simple organic acids and alcohols that can be fermented to produce acetate (table 23). Additionally, members of the Peptostreptococcaceae (Schleifer, 2009), Lachnospiraceae/Ruminococcaceae (Schleifer, 2009), Clostridiaceae (Schleifer, 2009), Desulfobacteraceae (Kuever and others, 2005), and Thermoprotei (Garrity and Holt, 2001b) produce and release acetate as a byproduct of fermentative or heterotrophic metabolism. Collectively, these groups of bacteria provide the reactants that drive dissimilatory biogeochemical reactions (energy production) and substrates for biomass production. Members of the Euryarchaeota are efficient methanogens (table 3, reactions 3, 4 and 5) (Methanopyri, Methanobacteria, Methanococci and Thermoplasmata) and anaerobic methane oxidizers (table 3, reaction 12) (Methanomicrobia: ANME-1 and ANME-3) (Garrity and Holt, 2001a). However, OTUs were also identified that represent methanogenic syntrophic bacteria, which enable methanogenesis to proceed in the presence of sulfate reducing bacteria by removing $\mathrm{H}_{2}$ from the system. Members of the SAGMEG group have not been characterized or cultured to date. OTUs similar to sequences in this group have been recovered from the sulfate-methane transition zone in anaerobic and stratified ecosystems (Teske and Sørensen, 2007).

Nitrogen is a critical nutrient for bacterial cell maintenance and production because of its being an integral component of amino acids and proteins (for example, enzymes and membranes). Accordingly, nitrogen cycling is extremely important in this type of ecosystem, because allochthonous introductions of nitrogen (that is, nitrates and nitrites) and aerobic nitrogen fixation do not occur. Additionally, the absence of nitrates and nitrites in this region of the Upper Floridan aquifer prevents denitrification and anaerobic ammonia oxidation (ANAMMOX) processes from proceeding. Ammonia was present in all of the groundwater samples analyzed during this study. This form of nitrogen is required by all bacterial species and is the form of nitrogen most easily metabolized by bacterial cells. The source of ammonia cannot be explained by terrestrial inputs or in situ chemolithotrophic reactions that rely on nitrates or nitrites being present. The most likely source is the ammonification of bacterial cell lysates that originate from cell death or viral lysis. Representatives in four of the classifications in table 23 are capable of ammonification. 
Table 22. Bacterial diversity based on the family classifications.

[\%, percent; ND, not determined; NA, not applicable]

\begin{tabular}{|c|c|c|c|c|c|c|}
\hline Bacterial family classification & Sample 1 & Sample 2 & Percent change & Sample 1 & Sample 2 & Percent change \\
\hline & & $42 \mathrm{U}$ & & & $42 \mathrm{~L}$ & \\
\hline Pseudomonadaceae & $39.71 \%$ & $53.85 \%$ & $14.14 \%$ & $28.17 \%$ & $70.76 \%$ & $42.59 \%$ \\
\hline Peptostreptococcaceae & $2.94 \%$ & $4.07 \%$ & $1.13 \%$ & $9.86 \%$ & $4.87 \%$ & $-4.99 \%$ \\
\hline Lachnospiraceae/Runinococcaceae & $2.94 \%$ & $5.88 \%$ & $2.94 \%$ & $14.08 \%$ & $3.81 \%$ & $-10.27 \%$ \\
\hline Anaerolineaceae & $20.59 \%$ & $6.33 \%$ & $-14.25 \%$ & $12.68 \%$ & $5.72 \%$ & $-6.96 \%$ \\
\hline Desulfobacteraceae & $7.35 \%$ & $8.14 \%$ & $0.79 \%$ & $4.23 \%$ & $5.72 \%$ & $1.49 \%$ \\
\hline Micrococcinea & ND & $0.90 \%$ & $0.90 \%$ & ND & ND & NA \\
\hline Prevotellaceae & $5.88 \%$ & $10.41 \%$ & $4.52 \%$ & $7.04 \%$ & $3.60 \%$ & $-3.44 \%$ \\
\hline Thermoprotei & $8.82 \%$ & $5.43 \%$ & $-3.39 \%$ & $12.68 \%$ & $3.39 \%$ & $-9.29 \%$ \\
\hline \multirow[t]{2}{*}{ SAGMEG } & $11.76 \%$ & $4.98 \%$ & $-6.79 \%$ & $11.27 \%$ & $2.12 \%$ & $-9.15 \%$ \\
\hline & & $15 \mathrm{U}$ & & & $15 \mathrm{M}$ & \\
\hline Pseudomonadaceae & $11.97 \%$ & $85.69 \%$ & $73.73 \%$ & $37.80 \%$ & $92.50 \%$ & $54.70 \%$ \\
\hline Peptostreptococcaceae & $14.53 \%$ & $0.94 \%$ & $-13.59 \%$ & $18.29 \%$ & $0.60 \%$ & $-17.70 \%$ \\
\hline Lachnospiraceae/Runinococcaceae & $7.69 \%$ & $0.47 \%$ & $-7.22 \%$ & $3.66 \%$ & $0.36 \%$ & $-3.30 \%$ \\
\hline Anaerolineaceae & $16.24 \%$ & $3.30 \%$ & $-12.94 \%$ & $17.07 \%$ & $0.71 \%$ & $-16.36 \%$ \\
\hline Desulfobacteraceae & $22.22 \%$ & $4.25 \%$ & $-17.98 \%$ & $10.98 \%$ & $2.14 \%$ & $-8.83 \%$ \\
\hline Micrococcinea & $10.26 \%$ & $0.47 \%$ & $-9.78 \%$ & $1.22 \%$ & $0.36 \%$ & $-0.86 \%$ \\
\hline Prevotellaceae & $0.85 \%$ & ND & $-0.85 \%$ & $3.66 \%$ & ND & $-3.66 \%$ \\
\hline Thermoprotei & $9.40 \%$ & $3.14 \%$ & $-6.26 \%$ & $6.10 \%$ & $2.14 \%$ & $-3.95 \%$ \\
\hline \multirow[t]{2}{*}{ SAGMEG } & $6.84 \%$ & $1.73 \%$ & $-5.11 \%$ & $1.22 \%$ & $1.19 \%$ & $-0.03 \%$ \\
\hline & & MZ1 & & & MZ3 & \\
\hline Pseudomonadaceae & $0.35 \%$ & $94.76 \%$ & $94.41 \%$ & $26.08 \%$ & $46.72 \%$ & $20.65 \%$ \\
\hline Peptostreptococcaceae & $27.82 \%$ & $0.54 \%$ & $-27.28 \%$ & $16.55 \%$ & $3.49 \%$ & $-13.06 \%$ \\
\hline Lachnospiraceae/Runinococcaceae & $30.63 \%$ & $0.40 \%$ & $-30.23 \%$ & $19.27 \%$ & $0.44 \%$ & $-18.84 \%$ \\
\hline Anaerolineaceae & $2.46 \%$ & $1.08 \%$ & $-1.39 \%$ & $7.48 \%$ & $7.86 \%$ & $0.38 \%$ \\
\hline Desulfobacteraceae & $0.70 \%$ & $0.27 \%$ & $-0.44 \%$ & $6.58 \%$ & $6.55 \%$ & $-0.03 \%$ \\
\hline Micrococcinea & $15.14 \%$ & $0.13 \%$ & $-15.01 \%$ & $9.75 \%$ & $25.33 \%$ & $15.58 \%$ \\
\hline Prevotellaceae & $17.96 \%$ & ND & $-17.96 \%$ & $9.07 \%$ & ND & $-9.07 \%$ \\
\hline Thermoprotei & $2.11 \%$ & $1.48 \%$ & $-0.63 \%$ & $2.72 \%$ & $5.24 \%$ & $2.52 \%$ \\
\hline SAGMEG & $2.82 \%$ & $1.34 \%$ & $-1.47 \%$ & $2.49 \%$ & $4.37 \%$ & $1.87 \%$ \\
\hline
\end{tabular}

Sulfate reduction (reactions 1 and 2), which is the most energetically favorable biogeochemical process in this region of the Upper Floridan aquifer (fig. 14), is well represented by members of the Desulfobacteraceae, Thermoprotei, and Euryarchaeota (fig. 17, table 23). The sulfate concentrations measured in the groundwater sampled during this study are not limiting and sulfate reduction proceeds in the presence of methanogenesis. Sulfate reduction and methanogenesis are commonly considered mutually exclusive, with methane being absent or in very low concentrations in ecosystems until sulfate has been reduced to sulfide (Mitterer, 2010). Recent studies have shown, however, that both processes can co-occur in carbonate sediment systems, similar to the Upper Floridan aquifer, if the methanogens 
Table 23. Likely biogeochemical processes based on bacterial diversity in all of the sampling sites.

[OTU, operational taxonomic unit]

\begin{tabular}{|c|c|c|c|c|c|c|c|c|c|}
\hline \multirow[b]{2}{*}{ OTU Classification } & \multicolumn{9}{|c|}{ Physiological classification } \\
\hline & 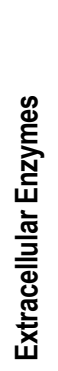 & 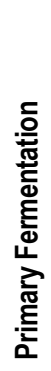 & 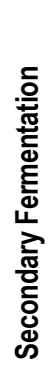 & 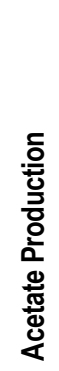 & 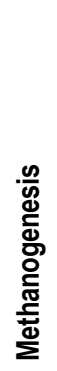 & 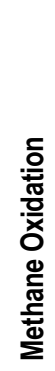 & 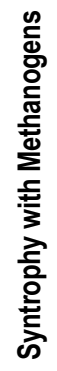 & 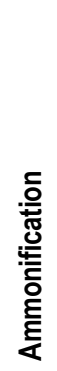 & 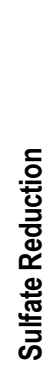 \\
\hline Pseudomonadaceae & $\mathrm{x}$ & $\mathrm{x}$ & & & & & & $\mathrm{x}$ & \\
\hline Peptostreptococcaceae & $\mathrm{x}$ & & & $\mathrm{x}$ & & & & $\mathrm{x}$ & \\
\hline Lachnospiraceae/Ruminococcaceae & $\mathrm{x}$ & $\mathrm{x}$ & $\mathrm{x}$ & $\mathrm{x}$ & & & & $\mathrm{x}$ & \\
\hline Clostridiaceae & $\mathrm{x}$ & $\mathrm{x}$ & $\mathrm{x}$ & $\mathrm{x}$ & & & $\mathrm{x}$ & & \\
\hline Anaerolineaceae & $\mathrm{x}$ & $\mathrm{x}$ & & & & & $\mathrm{x}$ & & \\
\hline Desulfobacteraceae & $\mathrm{x}$ & $\mathrm{x}$ & $\mathrm{x}$ & $\mathrm{x}$ & & & $\mathrm{x}$ & & $\mathrm{x}$ \\
\hline Micrococcineae & $\mathrm{x}$ & $\mathrm{x}$ & $\mathrm{x}$ & & & & & $\mathrm{x}$ & \\
\hline Prevotellaceae & $\mathrm{x}$ & $\mathrm{x}$ & & & & & & & \\
\hline Thermoprotei & $\mathrm{x}$ & $\mathrm{x}$ & $\mathrm{x}$ & $\mathrm{x}$ & & & & & $\mathrm{x}$ \\
\hline SAGMEG & \multicolumn{9}{|c|}{ (Bacteria belonging to this group are currently uncharacterized) } \\
\hline Geobacteraceae & & & & & & & $\mathrm{x}$ & & \\
\hline Planctomycetes & $\mathrm{x}$ & & & & & & & & \\
\hline Euryarchaeota & $\mathrm{x}$ & $\mathrm{x}$ & & & $\mathrm{x}$ & $\mathrm{x}$ & & & $\mathrm{x}$ \\
\hline
\end{tabular}

utilize noncompetitive substrates. Additionally, geochemical conditions similar to those in this region of the Upper Floridan aquifer have been modeled and a new concept for the co-occurrence of sulfate reduction and methanogenesis has been put forth that relies on the physical isolation of sulfate reducers from methanogens in the fractures and pore spaces of the rock matrix (Jakobsen, 2007). Sulfide and methane were detected in all of the groundwater samples; the energetics analyses found both type of reactions were energetically favorable, and the bacterial diversity analyses identified sulfate reducers and methanogens in all of the samples. These two biogeochemical reactions are co-occurring in the Upper Floridan aquifer and are critical for energy production and carbon cycling in this ecosystem.

Many groups of bacteria have physiological capabilities for performing biogeochemical reactions, even though the environmental conditions (such as the absence of chemical reactants) are not appropriate for those reactions to be initiated. The bacterial diversity analyses detected OTUs in this region of the Upper Floridan aquifer that have been shown to perform the following biogeochemical reactions or processes under nonphototrophic and anaerobic conditions: denitrification, ANAMMOX, nitrogen fixation, $\mathrm{Fe}(\mathrm{III})$ reduction, $\mathrm{Fe}(\mathrm{II})$ oxidation (nitrate dependent), elemental sulfur respiration, arsenite oxidation, arsenate reduction, chlorinated hydrocarbon degradation, and hydrocarbon (crude oil) degradation. Although this is not an exhaustive list from the PhyloChip data, those reactions and processes listed may of interest to groundwater resource managers responsible for (1) designing and monitoring managed recharge/recovery facilities, (2) remediating accidental contamination events, and (3) geochemical modeling. 


\section{Future Research Directions}

1. Although a representative of the total coliform group was chosen as the model microbial indicator for this study, pathogenic bacteria, protozoan parasites, and viruses are of equal or greater public health concern. The aboveground, flowthrough mesocosms used during this study can also be adapted to retain and study these microorganisms. Because the native conditions in the UFA and APPZ were shown to have a negative effect on the survival of E. coli, relative to the conditions analyzed in other groundwater studies, characterizing the inactivation rates of these other microbial indicators and pathogens in these zones would be of interest to public health, regulatory, and resource-management officials.

2. This study focused on the suspended bacterial communities in the Upper Floridan aquifer; however, it is generally accepted that the majority of the microbial biomass in any subsurface ecosystem is associated with the attached or biofilm communities (Pedersen, 2012; Whitman and others, 1998). Using the same approaches described in this study to characterize the functional diversity and rates of biogeochemical reactions associated with biofilms in the UFA and APPZ would provide a significant contribution to the understanding of how these zones respond to native conditions and recharge events.

1. The inactivation of microbial indicators to satisfy primary drinking-water standards is required for some groundwater recharge methods. Although oxidizing disinfectants (such as chlorine and chloramines) are routinely used in potable-water treatment facilities prior to distribution, their use for treating recharge water prior to injection is discouraged because of the formation of disinfection byproducts. Alternative types of disinfectants, such as UV irradiation, are commonly used for treating these types of recharge water. The efficacy of UV irradiation can be compromised, however, by dissolved constituents, leading to injured microbial indicators that appear to be inactivated when using required water-quality monitoring methods (Blatchley and others, 2007; Lisle and others, 1998, 1999). Because UV irradiation is a commonly used disinfectant for recharge water in Florida, assessing the inactivation and recovery rates of bacterial, protozoan, and viral contaminants during and following treatment and during storage would assist public health and regulatory officials in determining appropriate disinfectants and dosages to maintain a product that satisfies regulatory standards.

\section{References Cited}

Aiken, G.R., 1992, Chloride interference in the analysis of dissolved organic carbon by the wet oxidation method: Environmental Science \& Technology, v. 26, p. 2435-2439.

Aiken, G.R., McKnight, D.M., Thorn, K.A., and Thurman, E.M., 1992, Isolation of hydrophilic organic acids from water using nonionic macroporous resins: Organic Geochemistry, v. 18, p. 567-573.

Allison, S., and Martiny, J., 2008, Resistance, resilience, and redundancy in microbial communities: Proceedings of the National Academy of Sciences, v. 105, p. 11512-11519.

Amann, R.I., Ludwig, W., and Schleifer, K.H., 1995, Phylogenetic identification and in situ detection of individual microbial cells without cultivation: Microbiology and Molecular Biology Reviews, v. 59, p. 143-169. 
Amend, J., and Shock, E., 2001, Energetics of overall metabolic reactions of thermophilic and hyperthermophilic Archaea and Bacteria: FEMS Microbiology Reviews, v. 25, p. 175-243.

Anderson, R., Brazelton, W., and Baross, J., 2013, The deep viriosphere-Assessing the viral impact on microbial community dynamics in the deep subsurface: Reviews in Mineralogy and Geochemistry, v. 75, p. 649-675.

Anonymous, 1989, National Primary Drinking Water Regulations; Total Coliforms: Federal Register, v. 54, no. 124 , p. 27544-27568.

Anonymous, 2012, Sewage disposal facilities; advanced and secondary waste treatment: v. Title XXIX (Public Health), Chapter 403 (Environmental Control), Part I (Pollution Control), Section $403.086(9)(\mathrm{g})$.

Anonymous, 2013a, Drinking water standards, monitoring, and reporting: v. Floridan Administrative Code 62-550, p. 102-828.

Anonymous, 2013b, Ground water classes, standards, and exemptions: v. Floridan Administrative Code 62-520, p. 200-900.

Anonymous, 2013c, Underground injection control: v. Floridan Administrative Code 62-528, p. 100-900.

Barer, M., Gribbon, L., Harwood, C., and Nwoguh, C., 1993, The viable but non-culturable hypothesis and medical bacteriology: Reviews in Medical Microbiology, v. 4, p. 183-191.

Barer, M. and Harwood, C., 1999, Bacterial viability and culturability: Advances in Microbial Physiology, v. 41, p. 94-137.

Bastviken, D., and Tranvik, L., 2001, The leucine incorporation method estimates bacterial growth equally well in both oxic and anoxic lake waters: Applied and Environmental Microbiology, v. 67 , p. 2916-2921.

Bissonnette, G., Jezeski, J., McFeters, G., and Stuart, D., 1975, Influence of environmental stress on enumeration of indicator bacteria from natural waters: Applied Microbiology, v. 29, p. 186-194.

Blatchley, E., Gong, W., Alleman, J., Rose, J., Huffman, D., Otaki, M., and Lisle, J., 2007, Effects of wastewater disinfection on waterborne bacteria and viruses: Water Environmental Research, v. 79, p. 81-92.

Bradner, L., 1991, Water quality in the Upper Floridan aquifer in the vicinity of drainage wells, Orlando, Florida: U.S. Geological Survey Water-Resources Investigations Report, 90-4175, 57 p.

Buesing, N., and Marxsen, J., 2005, Theroretical and empirical conversion factors for determining bacterial production in freshwater sediments via leucine incorporation: Limnology and Oceanography Methods, v. 3, p. 101-107.

Bush, P., and Johnston, R., 1988, Ground-water hydraulics, regional flow, and ground-water development of the Floridan aquifer system in Florida and in parts of Georgia, South Carolina, and Alabama: U.S. Geological Survey Professional Paper, 1403-C, 80 p. 
Caldwell, S., Laidler, J., Brewer, E., Eberly, J., Sandborgh, S., and Colwell, F., 2008, Anaerobic oxidation of methane-Mechanisms, bioenergetics, and the ecology of associated microorganisms: Environmental Science \& Technology, v. 42, p. 6791-6799.

Cerf, O., 1977, A review-Tailing of survival curves of bacterial spores: Journal of Applied Microbiology, v. 42, p. 1-19.

Chapelle, F., 2000, The significance of microbial processes in hydrogeology and geochemistry: Hydrogeology Journal, v. 8, p. 41-46.

Chapelle, F., Vroblesky, D., Woodward, J., and Lovley, D., 1997, Practical considerations for measuring hydrogen concentrations in groundwater: Environmental Science \& Technology, v. 31, p. 2873-2877.

Crane, S., and Moore, J., 1986, Modeling enteric bacterial die-off-A review: Water Air Soil Pollution, v. 27, p. 411-439.

Davidson, M., Silver, B., Onstott, T., Moser, D., Gihring, T., Pratt, L., Boice, E., Lollar, B., LippmannPipke, J., Pfiffner, S., Kieft, T., Seymore, W., and Ralston, C., 2011, Capture of planktonic microbial diversity in fractures by long-term monitoring of flowing boreholes, Evander Basin, South Africa: Geomicrobiology Journal, v. 28, p. 275-300.

DeAngelis, K.M., Allgaier, M., Chavarria, Y., Fortney, J.L., Hugenholtz, P., Simmons, B., Sublette, K., Silver, W.L., and Hazen, T.C., 2011, Characterization of trapped lignin-degrading microbes in tropical forest soil: PLoS ONE, v. 6, p. e19306.

del Giorgio, P., and Cole, J., 1998, Bacterial growth efficiency in natural aquatic systems: Annual Review of Ecology and Systematics, v. 29, p. 503-541.

DeSantis, T., Brodie, E., Moberg, J., Zubieta, I., Piceno, Y., and Andersen, G., 2007, High-Density universal 16S rRNA microarray analysis reveals broader diversity than typical clone library when sampling the environment: Microbial Ecology, v. 53, p. 371-383.

Dick, J., 2008, Calculation of the relative metastabilities of proteins using the CHNOSZ software package: Geochemical Transactions, v. 9, p. 1-17.

Ferry, J., and Lessner, D., 2008, Methanogenesis in marine sediments: Annals of the New York Academy of Sciences, v. 1125, p. 147-157.

Finkel, S., Zinser, E., and Kolter, R., 2000, Long-term survival and evolution in the stationary phase, in Storz, G., and Hengge-Aronis, R., eds., Bacterial Stress Responses: ASM Press, p. 231-238.

Fredrickson, J., and Balkwill, D., 2006, Geomicrobial processes and biodiversity in the deep terrestrial subsurface: Geomicrobiology Journal, v. 23, p. 345-356.

Garrity, G., Bell, J., and Lilburn, T., 2005, Pseudomonadales Orla-Jensen 1921, 270, in Brenner, D.J., Krieg, N.R., and Staley, J.T., eds., Bergey's manual of systematic bacteriology ( $2 \mathrm{~d}$ ed), v. 2, The Proteobacteria: part B, The Gammaproteobacteria: Springer, p. 323-442.

Garrity, G., and Holt, D., 2001a, Phylum AII. Euryarchaeota phy. nov., in, Boone, D.R. and Castenholz, R.W., eds., Bergey's manual of systematic bacteriology ( $2 \mathrm{~d}$ ed), v. 1., The Archaea and the deeply branching and phototrophic Bacteria: New York, Springer p. 211-355. 
Garrity, G., and Holt, J., 2001b, Phylum AI. Crenarchaeota phy. nov., in Boone, D.R., and Castenholz, R.W., eds., Bergey's manual of systematic bacteriology ( $2 \mathrm{~d}$ ed), v. 1, The Archaea and the deeply branching and phototrophic Bacteria: New York, Springer, p. 169-210.

Goodfellow, M., 2012, Phylum XXVI. Actinobacteria phy. nov, in Whitman, W.B., Goodfellow, M., Kämpfer, P., Busse, H.J., Trujillo, M.E., Ludwig, W., Suzuki, K., and Parte, A., eds., Bergey's manual of systematic bacteriology (2d ed), v. 5, The Actinobacteria: Springer, p. 33-2028.

Hazen, T., Dubinsky, E., DeSantis, T., Andersen, G., Piceno, Y., Singh, N., Jansson, J., Probst, A., Borglin, S., Fortney, J., Stringfellow, W., Bill, M., Conrad, M., Tom, M., Chavarria, K., Alusi, T., Lamendella, R., Joyner, D., Spier, C., Baelum, J., Auer, M., Zemla, M., Chakraborty, R., Sonnenthal, E., D’haeseleer, P., Holman, H., Osman, S., Lu, Z., Van Nostrand, J., Deng, Y., Zhou, J., and Mason, O., 2010, Deep-sea oil plume enriches indigenous oil-degrading bacteria: Science, v. 330, p. 204-208.

Ho, A., Luke, C., and Frenzel, P., 2011, Recovery of methanotrophs from disturbance-Population dynamics, evenness and functioning: International Society for Microbial Ecology Journal, v. 5, p. 750-758.

Hobbie, J., 1973, Using kinetic analyses of uptake of carbon-14 to measure rates of movement of individual organic compounds into aquatic bacteria: Bulletins from the Ecological Research Committee, p. 207-214.

Hoben, H.J., and Somasegaran, P., 1982, Comparison of the pour, spread, and drop plate methods for enumeration of Rhizobium spp. in inoculants made from presterilized peat: Applied and Environmental Microbiology, v. 44, p. 1246-1247.

Hoehler, T., Alperin, M., Albert, D., and Martens, C., 1998, Thermodynamic control on hydrogen concentrations in anoxic sediments: Geochimica et Cosmochimica Acta, v. 62, p. 1745-1756.

Hoehler, T., and Jorgensen, B., 2013, Microbial life under extreme energy limitation: Nature Reviews Microbiology, v. 11, p. 83-94.

Jakobsen, R., 2007, Redox microniches in groundwater: a model study on the geometric and kinetic conditions required for concomitant $\mathrm{Fe}$ oxide reduction, sulfate reduction, and methanogenesis: Water Resources Research, v. 43, p. 1-11.

Jiao, N., Azam, F., and Sanders, S., 2011, The microbial carbon pump in the ocean: American Association for the Advancement of Science, Washington, D.C. 68 p.

John, D., 2003, Transport and survival of water quality indicator microorganisms in the ground water environment of Florida-Implications for aquifer storage and waste disposal: University of South Florida, Tampa, Ph.D. dissertation, 322 p.

John, D., and Rose, J., 2005, Review of factors affecting microbial survival in groundwater: Environmental Science \& Technology, v. 39, p. 7345-7356.

Johnston, R., and Bush, P., 1988, Summary of the hydrology of the Floridan aquifer system in Florida and in parts of Georgia, South Carolina, and Alabama: U.S. Geological Survey Professional Paper, $1403-\mathrm{A}, 32 \mathrm{p}$. 
Kell, D., Kaprelyants, A., Weichart, D., Harwood, C., and Barer, M., 1998, Viability and activity in readily culturable bacteria-A review and discussion of the practical issues: Antonie van Leeuwenhoek, v. 73, p. 169-187.

Kenny, J., Barber, N., Hutson, S., Linsey, K., Lovelace, J., and Maupin, M., 2005, Estimated use of water in the United States in 2005: U.S. Geological Survey Circular 1344, 52 p.

Keswick, B., Gerba, C., Secor, S., and Cech, I., 1982, Survival of enteric viruses and indicator bacteria in groundwater: Journal of Environmental Science and Health. Part A: Environmental Science and Engineering, v. 17, p. 903-912.

Kirchman, D., 1993, Leucine incorporation as a measure of biomass production by heterotrophic bacteria, in Kemp, P., Sherr, B., Sherr, E., Cole, J., eds., Handbook of methods in aquatic microbial ecology: CRC Press, p. 509-512.

Kirchman, D., 2001, Measuring bacterial biomass production and growth rates from leucine incorporation in natural aquatic environments, chap. 12 in Paul J., ed., Marine microbiology: Academic Press, Methods in Microbiology, v. 30, p. 227-237.

Kirchman, D., and Ducklow, H., 1993, Estimating conversion factors for the thymidine and leucine methods for measuring bacterial production, in Kemp, P., Sherr, B., Sherr, E., Cole, J., eds., Handbook of methods in aquatic microbial ecology: CRC Press, p. 513-517.

Knittel, K., and Boetius, A., 2009, Anaerobic oxidation of methane: progress with an unknown process: Annual Review of Microbiology, v. 63, p. 311-334.

Koch, A., 1990, Diffusion: the crucial process in many aspects of the biology of bacteria: Advances in Microbial Ecology, v. 11, p. 37-70.

Krause, R., and Randolph, R., 1989, Hydrology of the Floridan aquifer system in southeast Georgia and adjacent parts of Florida and South Carolina: U.S. Geological Survey Professional Paper, 1403-D, 65 p.

Krieg, N., Ludwig, W., and Euzeby, J., Whitman, W., 2010, Phylum XIV. Bacteroidetes phy. nov., in Krieg, N.R., Ludwig, W., Whitman, W.B., Hedlund, B.P., Paster, B.J., Staley, J.T., Ward, N., Brown, D., and Parte, A., eds., Bergey's manual of systematic bacteriology ( $2 \mathrm{~d} \mathrm{ed})$, v. 4: The Bacteroidetes, Spirochaetes, Tenericutes (Mollicutes), Acidobacteria, Fibrobacteres, Fusobacteria, Dictyoglomi, Gemmatimonadetes, Lentisphaerae, Verrucomicrobia, Chlamydiae, and Planctomycetes : New York, Springer, p. 25-469.

Kristjansson, J., Schonheit, P., and Thauer, R., 1982, Different $\mathrm{K}_{\mathrm{s}}$ values for hydrogen of methanogenic bacteria and sulfate reducing bacteria: an explanation for the apparent inhibition of methanogenesis by sulfate: Archives of Microbiology, v. 131, p. 278-282.

Kuever, J., Rainey, F., and Widdel, F., 2005, Class IV. Deltaproteobacteria class nov., in Brenner, D.J., Krieg, N.R., and Staley, J.T., eds., Bergey's manual of systematic bacteriology (2d ed), v. 2, The Proteobacteria, part C, The Alpha-, Beta-, Delta, and Epsilonproteobacteria: Springer, p. 922-1144.

LeChevallier, M., Cameron, S., and McFeters, G., 1983, New medium for improved recovery of coliform bacteria from drinking water: Applied and Environmental Microbiology, v. 45, p. 484-492. 
Lee, S., and Fuhrman, J., 1987, Relationships between biovolume and biomass of naturally derived marine bacterioplankton: Applied and Environmental Microbiology, v. 53, p. 1298-1303.

Lin, L., Wang, P., Rumble, D., Lippmann-Pipke, J., Boice, E., Pratt, L., Lollar, B., Brodie, E., Hazen, T., Andersen, G., DeSantis, T., Moser, D., Kershaw, D., and Onstott, T., 2006, Long-term sustainability of a high-energy, low-diversity crustal biome: Science, v. 314, p. 479-482.

Lisle, J., 2005, Characterization of the native microbial communities in Floridan aquifer waters targeted for aquifer storage and recovery (ASR) applications, south central Florida: U.S. Geological Survey Open-File Report 2005-1036, 24 p.

Lisle, J., Broadaway, S., Prescott, A., Pyle, B., Fricker, C., and McFeters, G., 1998, Effects of starvation on physiological activity and chlorine disinfection resistance in Escherichia coli O157:H7: Applied and Environmental Microbiology, v. 64, p. 4658-4662.

Lisle, J., and Priscu, J., 2004, The occurrence of lysogenic bacteria and microbial aggregates in the lakes of the McMurdo Dry Valleys, Antarctica: Microbial Ecology, v. 47, p. 427-439.

Lisle, J., Pyle, B., and McFeters, G., 1999, The use of multiple indices of physiological activity to access viability in chlorine disinfected Escherichia coli O157:H7: Letters in Applied Microbiology, v. 29, p. 42-47.

Liu, Y., and Whitman, W., 2008, Metabolic, phylogenetic, and ecological diversity of the methanogenic archaea: Annals of the New York Academy of Sciences, v. 1125, p. 171-189.

Lovley, D., Dwyer, D., and Klug, M., 1982, Kinetic analysis of competition between sulfate reducers and methanogens for hydrogen in sediments: Applied and Environmental Microbiology, v. 43, p. 1373-1379.

Maslia, M., and Hayes, L., 1988, Hydrogeology and simulated effects of ground-water development of the Floridan aquifer system, southwest Georgia, northwest Floridan and southwest Alabama: U.S. Geological Survey Professional Paper 1403-H, 71 p.

Mathias, M., Lasse, R., Grieg, F., Vinni, H., and Ole, N., 2003, Virus-induced transfer of organic carbon between marine bacteria in a model community: Aquatic Microbial Ecology, v. 33, p. 1-10.

McDougald, D., Rice, S., Weichart, D., and Kjelleberg, S., 1998, Nonculturability-Adaptation or debilitation?: FEMS Microbiology Ecology, v. 25, p. 1-9.

McFeters, G., 1990, Enumeration, occurrence, and significance of injured indicator bacteria in drinking water, in McFeters, Gordon, ed., Drinking water microbiology: New York, Springer, p. 478-492.

McFeters, G., Bissonnette, G., Jezeski, J., Thomson, C., and Stuart, D., 1974, Comparative survival of indicator bacteria and enteric pathogens in well water: Applied Microbiology, v. 27, p. 823-829.

McFeters, G., and Stuart, D., 1972, Survival of coliform bacteria in natural waters -Field and laboratory studies with membrane-filter chambers: Applied Microbiology, v. 24, p. 805-811.

McFeters, G., and Terzieva, S., 1991, Survival of Escherichia coli and Yersinia enterocolitica in stream water-Comparison and field and laboratory exposure: Microbial Ecology, v. 22, p. 65-74. 
McKnight, D.M., Boyer, E.W., Westerhoff, P.K., Doran, P.T., Kulbe, T., and Andersen, D.T., 2001, Spectrofluorometric characterization of dissolved organic matter for indication of precursor organic material and aromaticity: Limnology and Oceanography, v. 46, p. 38-48.

Megonigal, J., Hines, M., and Visscher, P., 2003, Anaerobic metabolism-Linkages to trace gases and aerobic processes: Treatise on Geochemistry, v. 8, p. 317-424.

Meyer, F., 1989, Hydrogeology, ground-water movement, and subsurface storage in the Floridan aquifer system in southern Florida: U.S. Geological Survey Professional Paper, 1403-G, 64 p.

Middelboe, M., and Jørgensen, N., 2006, Viral lysis of bacteria-An important source of dissolved amino acids and cell wall compounds: Journal of the Marine Biological Association of the United Kingdom, v. 86, p. 605-612.

Miller, J., 1986, Hydrogeologic framework of the Floridan aquifer system in Florida and in parts of Georgia, Alabama, and South Carolina: U.S. Geological Survey Professional Paper, 1403-B, 98 p.

Miller, L., 1990, Ground water atlas of the United States: Alabama, Florida, Georgia, and South Carolina: U.S. Geological Survey Hydrologic Atlas, Section 730-G, 30 p.

Mirecki, J., 2006, Geochemical models of water-quality changes during aquifer storage recovery (ASR) cycle tests, phase I-Geochemical models using existing data:, U.S. Army Engineer Research \& Development Center, Vicksburg, Miss., ERDC/EL-TR-06-8, 64 p.

Mirecki, J., 2013, Lake Okeechobee ASR pilot project technical data report:, U.S. Army Corp of Engineers, Jacksonville, Fla., 300 p.

Mitterer, R., 2010, Methanogenesis and sulfate reduction in marine sediments-A new model: Earth and Planetary Science Letters, v. 295, p. 358-366.

Mitterer, R., Malone, M., Goodfriend, G., Swart, P., Wortmann, U., Logan, G., Feary, D., and Hine, A., 2001, Co-generation of hydrogen sulfide and methane in marine carbonate sediments: Geophysical Research Letters, v. 28, p. 3931-3934.

Noble, R., and Fuhrman, J., 1999, Breakdown and microbial uptake of marine viruses and other lysis products: Aquatic Microbial Ecology, v. 20, p. 1-11.

Nystrom, T., 2004, Stationary-phase physiology: Annual Review of Microbiology, v. 58, p. 161-181.

Onstott, T., 2005, Impact of $\mathrm{CO}_{2}$ injections on deep subsurface microbial ecosystems and potential ramifications for the surface biosphere, in Benson, S., Oldenburg, C., Hoversten, M., Imbus, S., eds., Carbon Dioxide Capture for Storage in Deep Geologic Formations-Results from the $\mathrm{CO}_{2}$ Capture Project: Elsevier, p. 1207-1239.

Onstott, T., Lin, L., Davidson, M., Mislowack, B., Borcsik, M., Hall, J., Slater, G., Ward, J., Lollar, B., Lippmann-Pipke, J., Boice, E., Pratt, L.M., Pfiffner, S., Moser, D., Gihring, T., Kieft, T., Phelps, T., Vanheerden, E., Litthaur, D., DeFlaun, M., Rothmel, R., Wanger, G., and Southam, G., 2006, The origin and age of biogeochemical trends in deep fracture water of the Witwatersrand Basin, South Africa: Geomicrobiology Journal, v. 23, p. 369-414. 
Pedersen, K., 2012, Subterranean microbial populations metabolize hydrogen and acetate under in situ conditions in granitic groundwater at $450 \mathrm{~m}$ depth in the Äspö Hard Rock Laboratory, Sweden: FEMS Microbiology Ecology, v. 81, p. 217-229.

Phelps, T., Murphy, E., Pfiffner, S., and White, D., 1994, Comparison between geochemical and biological estimates of subsurface microbial activities: Microbial Ecology, v. 28, p. 335-349.

Plummer, N., and Sprinkle, C., 2001, Radiocarbon dating of dissolved inorganic carbon in groundwater from confined parts of the Upper Floridan aquifer, Florida, USA: Hydrogeology Journal, v. 9, p. $127-150$.

Poiencot, B., and Brown, C., 2011, An optimal centralized carbon dioxide repository for Florida, USA: International Journal of Environmental Research and Public Health, v. 8, p. 955-975.

Reasoner, D., and Geldreich, E., 1985, A new medium for the enumeration and subculture of bacteria from potable water: Applied and Environmental Microbiology, v. 49, p. 1-7.

Reese, R., and Alvarez-Zarikian, C., 2006, Hydrogeology and aquifer storage and recovery performance in the Upper Floridan aquifer, southern Florida: U.S. Geological Survey Scientific Investigations Report 2006-5239, 74 p.

Reese, R., and Richardson, E., 2008, Synthesis of the hydrogeological framework of the Floridan aquifer system and delineation of a major Avon Park permeable zone in central and southern Florida: U.S. Geological Survey Scientific Investigations Report 2007-5207, 60 p.

Renken, R., Cunningham, K., Zygnerski, M., Wacher, M., Shapiro, A.M., Harvey, R.W., Metge, D.W., Osborn, C., and Ryan, J.N., 2005, Assessing the vulnerability of a municipal well field to contamination in a karst aquifer: Environmental and Engineering Geoscience, v. 11, p. 319-331.

Robbins, L., Hansen, M., Kleypas, A., and Meylan, S., 2010, CO2calc-A user-friendly seawater carbon calculator for Windows, Max OS X, and iOS (iPhone): U.S. Geological Survey Open-File Report 2010-1280, 17 p.

Robinson, J., and Tiedje, J., 1984, Competition between sulfate-reducing and methanogenic bacteria for $\mathrm{H}_{2}$ under resting and growing conditions: Archives of Microbiology, v. 137, p. 26-32.

Roszak, D.B., and Colwell, R.R., 1987, Survival strategies of bacteria in the natural environment: Microbiological Reviews, v. 51, p. 365-379.

Russell, J.B., and Cook, G.M., 1995, Energetics of bacterial growth: balance of anabolic and catabolic reactions: Microbiological Reviews, v. 59, p. 48-62.

Ryder, P., 1985, Hydrology of the Floridan aquifer system in west-central Florida: U.S. Geological Survey Professional Paper 1403-F, 72 p.

Schink, B., 1997, Energetics of syntrophic cooperation in methanogenic degradation: Microbiology and Molecular Biology Reviews, v. 61, p. 262-280.

Schleifer, K., 2009, Phylum XIII. Firmicutes Gibbons and Murray 1978, 5 (Firmacutes [sic] Gibbons and Murray 1978, 5), in Vos, P., Garrity, G., Jones, D., Krieg, N.R., Ludwig, W., Rainey, F.A., 
Schleifer, K.-H., and Whitman, W.B., eds., Bergey's manual of systematic bacteriology (2d ed), v. 3, The Firmicutes: New York, Springer, p. 19-1317.

Schonheit, P., Kristjansson, J., and Thauer, R., 1982, Kinetic mechanism for the ability of sulfate reducers to out-compete methanogens for acetate: Archives of Microbiology, v. 132, p. 285-288.

Schulz, H., and Jorgensen, B., 2001, Big bacteria: Annual Review of Microbiology, v. 55, p. 105-137.

Shade, A., Read, J., Welkie, D., Kratz, T., Wu, C., and McMahon, K., 2011, Resistance, resilience and recovery-Aquatic bacterial dynamics after water column disturbance: Environmental Microbiology, v. 13 , p. 2752-2767.

Sidhu, J., and Toze, S., 2012, Assessment of pathogen survival potential during managed aquifer recharge with diffusion chambers: Journal of Applied Microbiology, v. 113, p. 693-700.

Simon, M., and Azam, F., 1989, Protein content and protein synthesis rates of planktonic marine bacteria: Marine Ecology Progress Series, v. 51, p. 201-213.

Sjostrom, J., Koch-Schmidt, P., Pontarp, M., Canback, B., Tunlid, A., Lundberg, P., Hagstrom, A., and Riemann, L., 2012, Recruitment of members from the rare biosphere of marine bacterioplankton communities after an environmental disturbance: Applied and Environmental Microbiology, v. 78, p. 1361-1369.

Spiers, A., Buckling, A., and Rainey, P., 2000, The causes of Pseudomonas diversity: Microbiology, v. 146, p. 2345-2350.

Sprinkle, C., 1989, Geochemistry of the Floridan aquifer system in Florida and in parts of Georgia, South Carolina, and Alabama: U.S. Geological Survey Professional Paper, 1403-I, 111 p.

Szulczewski, M., MacMinn, C., Herzog, H., and Juanes, R., 2012, Lifetime of carbon capture and storage as a climate-change mitigation technology: Proceedings of the National Academy of Sciences, v. 109 , p. $5185-5189$.

Terzieva, S., and McFeters, G., 1991, Survival and injury of Escherichia coli, Campylobacter jejuni, and Yersinia enterocolitica in stream water: Canadian Journal of Microbiology, v. 37, p. 785-790.

Teske, A., and Sørensen, K., 2007, Uncultured archaea in deep marine subsurface sediments-Have we caught them all?: International Society for Microbial Ecology Journal, v. 2, p. 3-18.

Thauer, R., Jungermann, K., and Decker, K., 1977, Energy conservation in chemotrophic anaerobic bacteria: Bacteriological Reviews, v. 41, p. 100-180.

Thauer, R., and Shima, S., 2008, Methane as fuel for anaerobic microorganisms: Annals of the New York Academy of Sciences, v. 1125, p. 158-170.

Tibbals, C., 1990, Hydrology of the Floridan aquifer system in east-central Florida: U.S. Geological Survey Professional Paper, 1403-E, 110 p.

U.S. Army Corps of Engineers and South Florida Water Management District, 1999, Central and Southern Florida Project Comprehensive Review Study: Final Integrated Feasibility Report and Programmatic Environmental Impact Statement: U.S. Army Corps of Engineers, Jacksonville, Fla., and South Florida Water Management District, West Palm Beach, Fla., 4034 p. 
U.S. Environmental Protection Agency, 2002, Method 1603: Escherichia coli (E. coli) in water by membrane filtration using modified membrane-thermotolerant Escherichia coli agar (modified mTEC): p. 1-13.

Ward, N., 2010, Phylum XXV. Planctomycetes Garrity and Holt 2001, 137 emend. Ward (this volume), in Krieg, N.R., Ludwig, W., Whitman, W.B., Hedlund, B.P., Paster, B.J., Staley, J.T., Ward, N., Brown, D., and Parte, A., eds., Bergey's manual of systematic bacteriology ( $2 \mathrm{~d}$ ed), v. 4, The Bacteroidetes, Spirochaetes, Tenericutes (Mollicutes), Acidobacteria, Fibrobacteres, Fusobacteria, Dictyoglomi, Gemmatimonadetes, Lentisphaerae, Verrucomicrobia, Chlamydiae, and Planctomycetes: New York, Springer, p. 879-925.

Weishaar, J.L., Aiken, G.R., Bergamaschi, B.A., Fram, M.S., Fujii, R., and Mopper, K., 2003, Evaluation of specific ultraviolet absorbance as an indicator of the chemical composition and reactivity of dissolved organic carbon: Environmental Science \& Technology, v. 37, p. 4702-4708.

Whitman, W., Coleman, D., and Wiebe, W., 1998, Prokaryotes-The unseen majority: Proceedings of the National Academy of Sciences, v. 95, p. 6578-6583.

Wright, R., 1978, Measurement and significance of specific activity in the heterotrophic bacteria of natural waters: Applied and Environmental Microbiology, v. 36, p. 297-305.

Wright, R., and Burnison, B., 1979, Heterotrophic activity measured with radiolabelled organic substrates, in Costerton, J., and Colwell, R., eds., Native aquatic Bacteria-Enumeration, activity, and ecology: ASTM Special Technical Publication 695, p. 140-155.

Wright, R., and Hobbie, J., 1966, Use of glucose and acetate by bacteria and algae in aquatic ecosystems: Ecology, v. 47, p. 447-464.

Xiong, R., Xie, G., Edmondson, A., and Sheard, M., 1999, A mathematical model for bacterial inactivation: International Journal of Food Microbiology, v. 46, p. 45-55.

Zaske, S., Dockins, W., and McFeters, G., 1980, Cell envelope damage in Escherichia coli caused by short-term stress in water: Applied and Environmental Microbiology, v. 40, p. 386-390.

Zimbro, M., Power, D., Miller, S., Wilson, G., and Johnson, J., 2009, Difco \& BBL manual-Manual of microbiological culture media (2d ed): Sparks, Md., BD Diagnostics, p. 1-686. 


\section{Appendix}

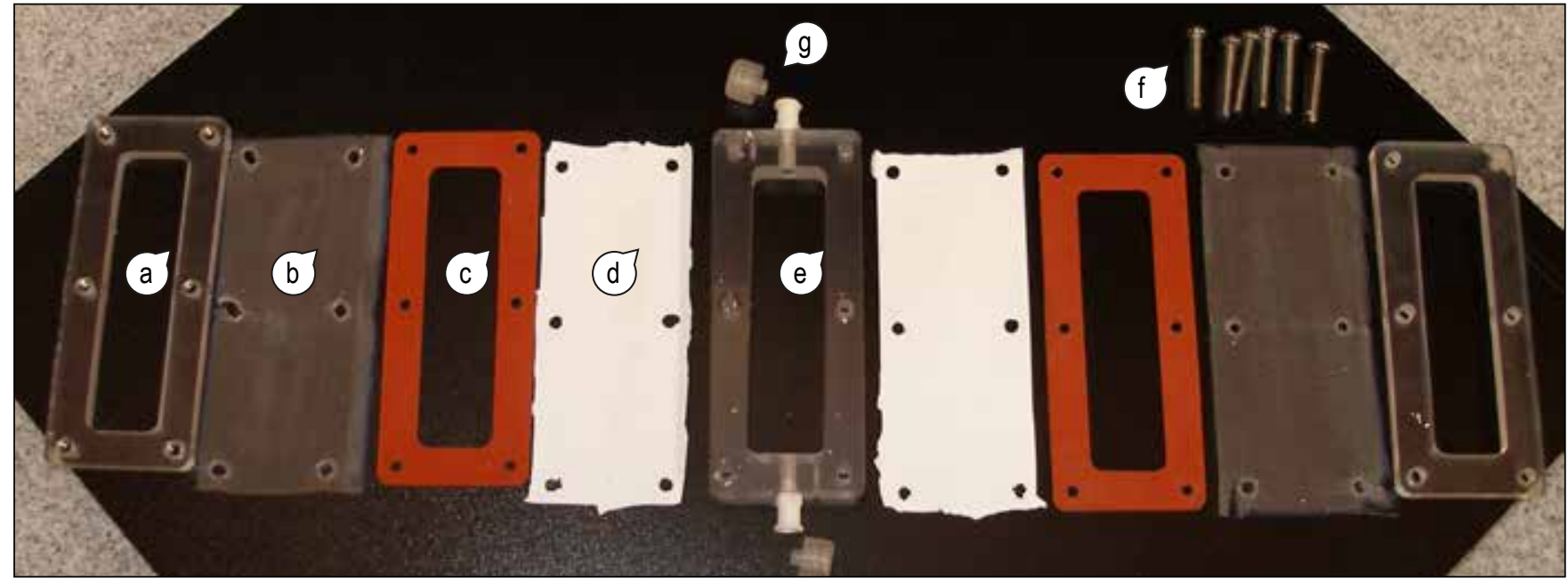

Figure 1-1. Diffusion chamber design: Each diffusion chamber was constructed by placing a membrane filter (d) on the central chamber (e), on which a silicon gasket (c) was placed. A polycarbonate screen (b) was placed on the gasket and the top chamber plate (a) placed on the screen. The same process was repeated for the other side of the central chamber and the completed chamber fastened and sealed with the six stainless steel bolts (f). The nylon syringe fittings on either end of the central chambers were closed using threaded polycarbonate caps (g).

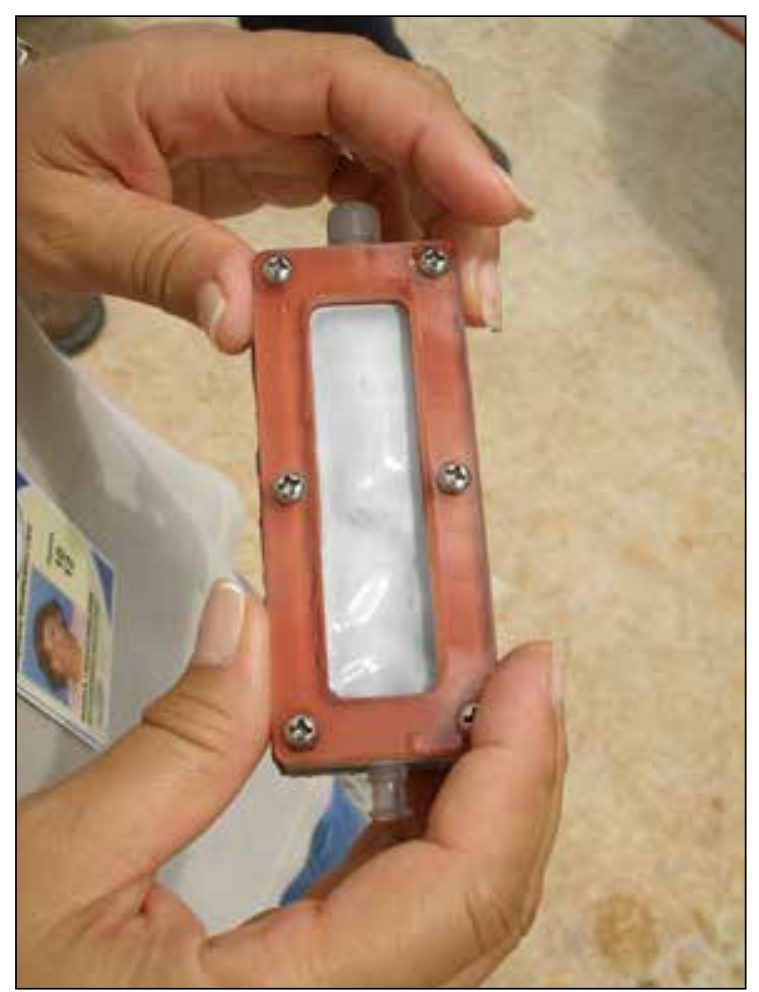

Figure 1-2. A completed diffusion chamber.

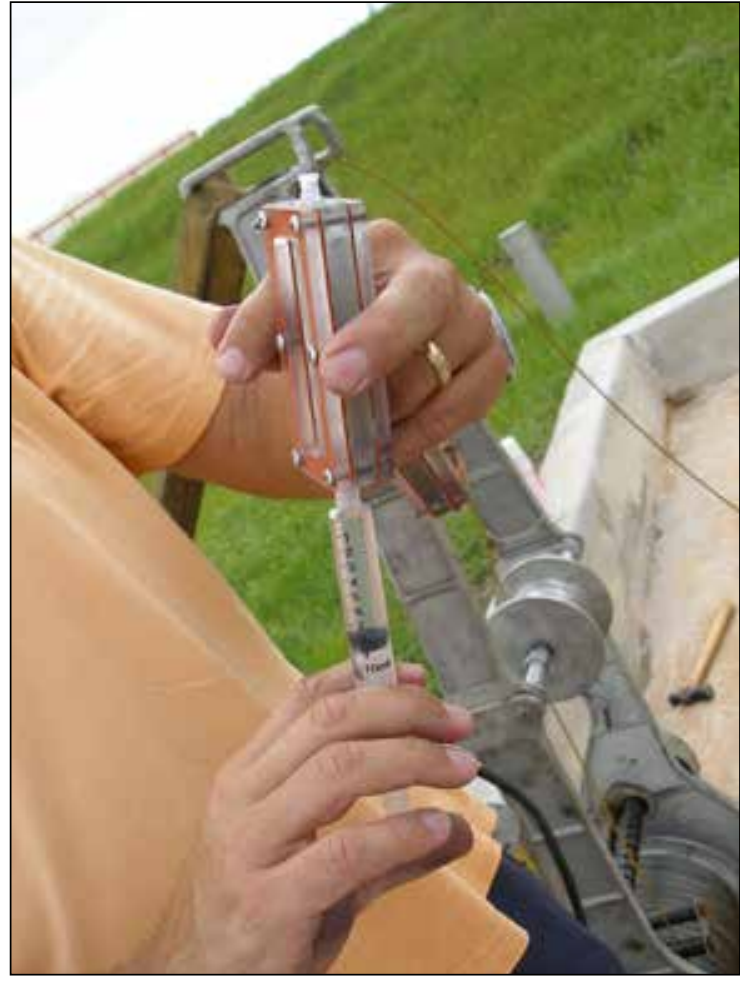

Figure 1-3. Loading a diffusion chamber with a culture of bacteria using a syringe. 


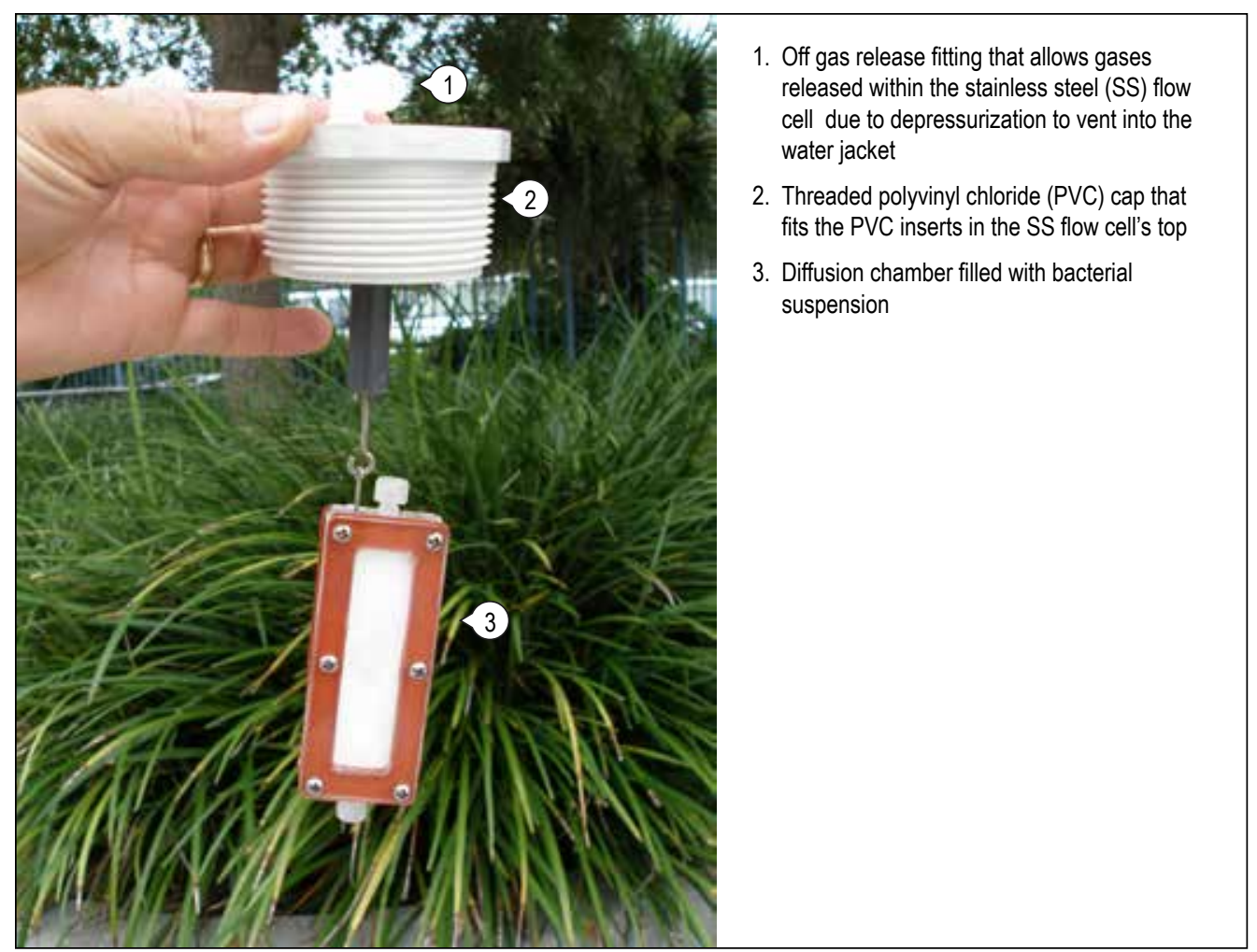

Figure 1-4. A diffusion chamber containing the bacterial culture suspended from a cap from the stainless steel flow-through chamber (See Figure 1-9).

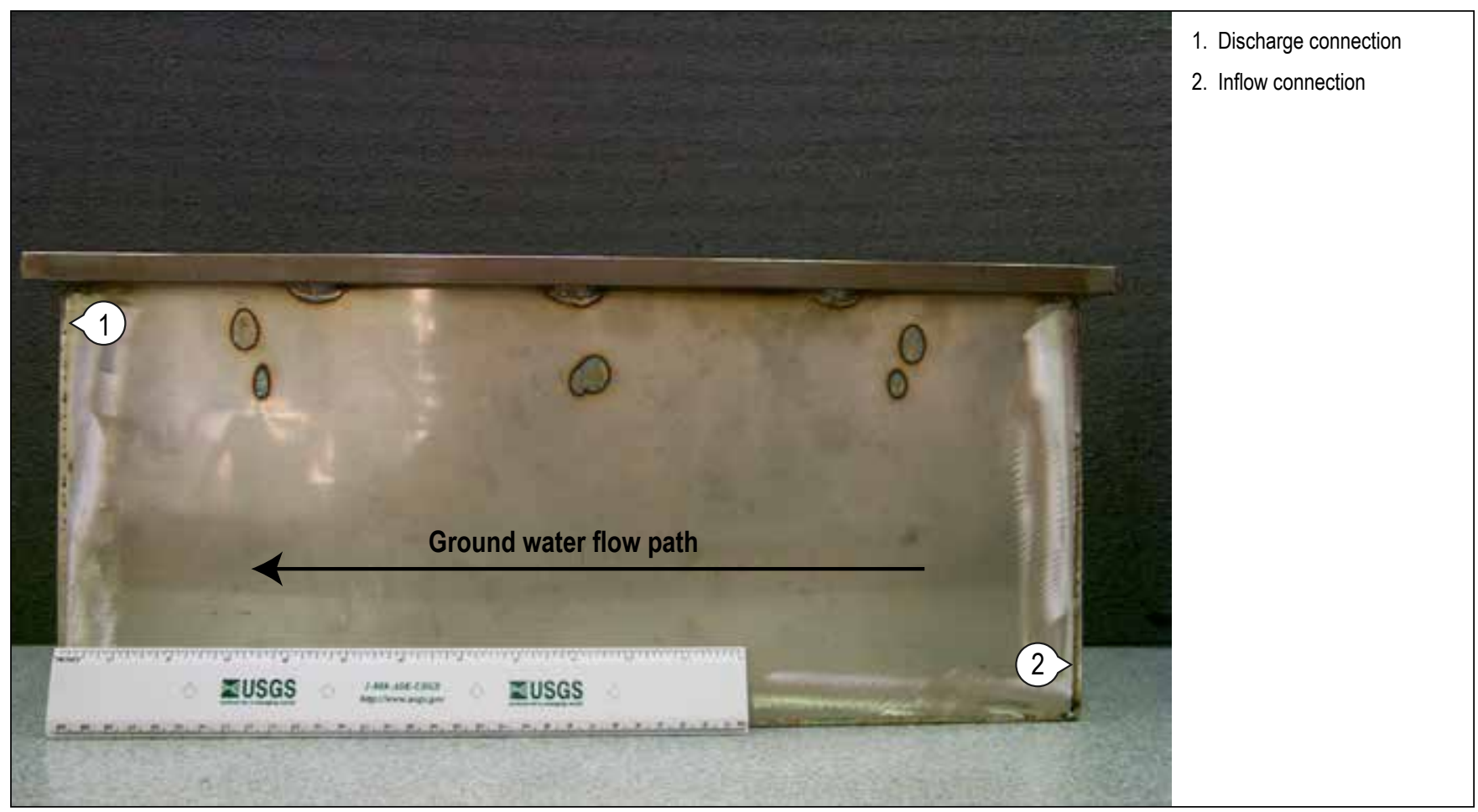

Figure 1-5. The stainless steel flow-through chamber (side view). 


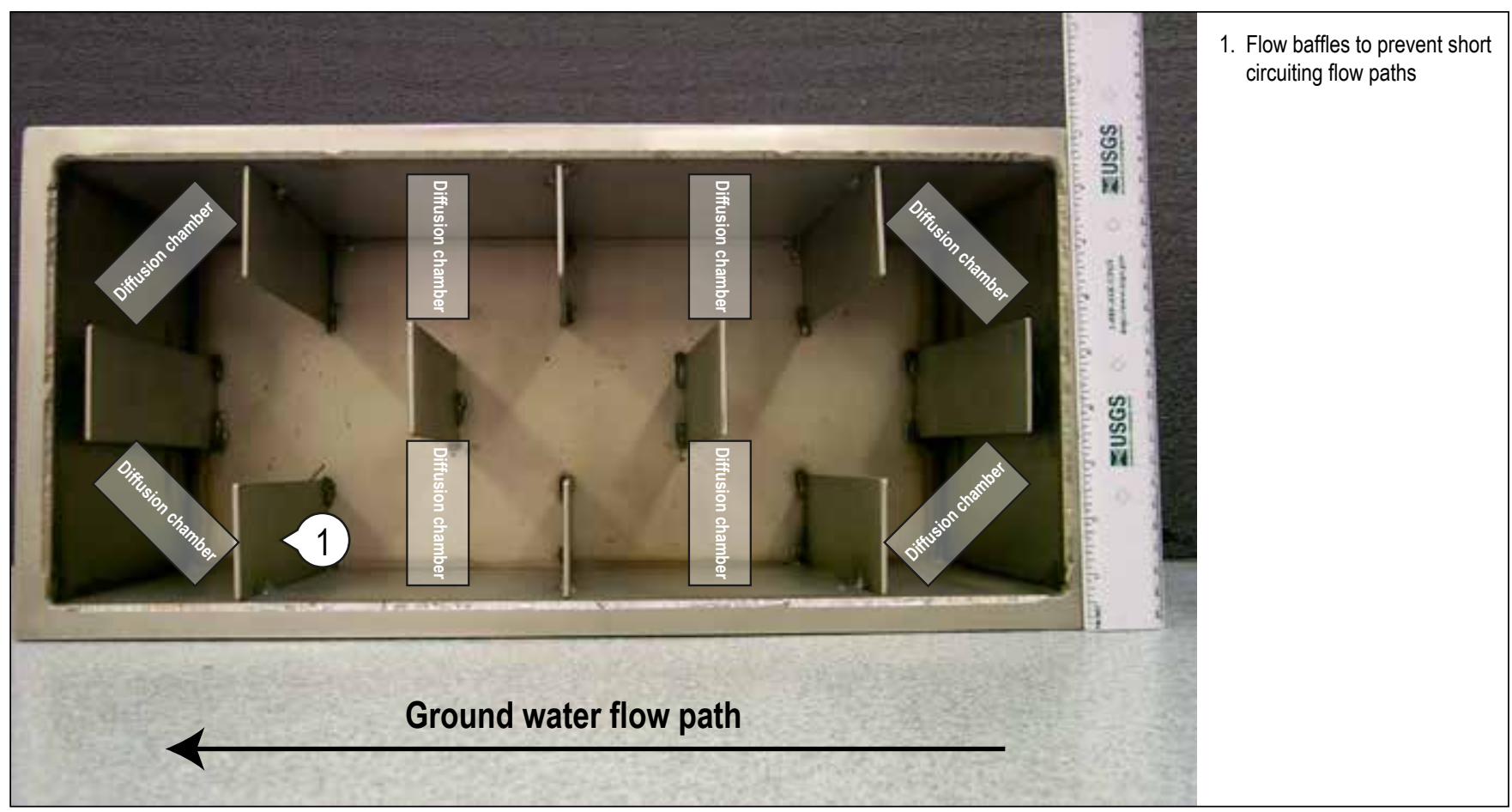

Figure 1-6. The stainless steel flow-through chamber showing the baffles and positions of the diffusion chambers (top view).

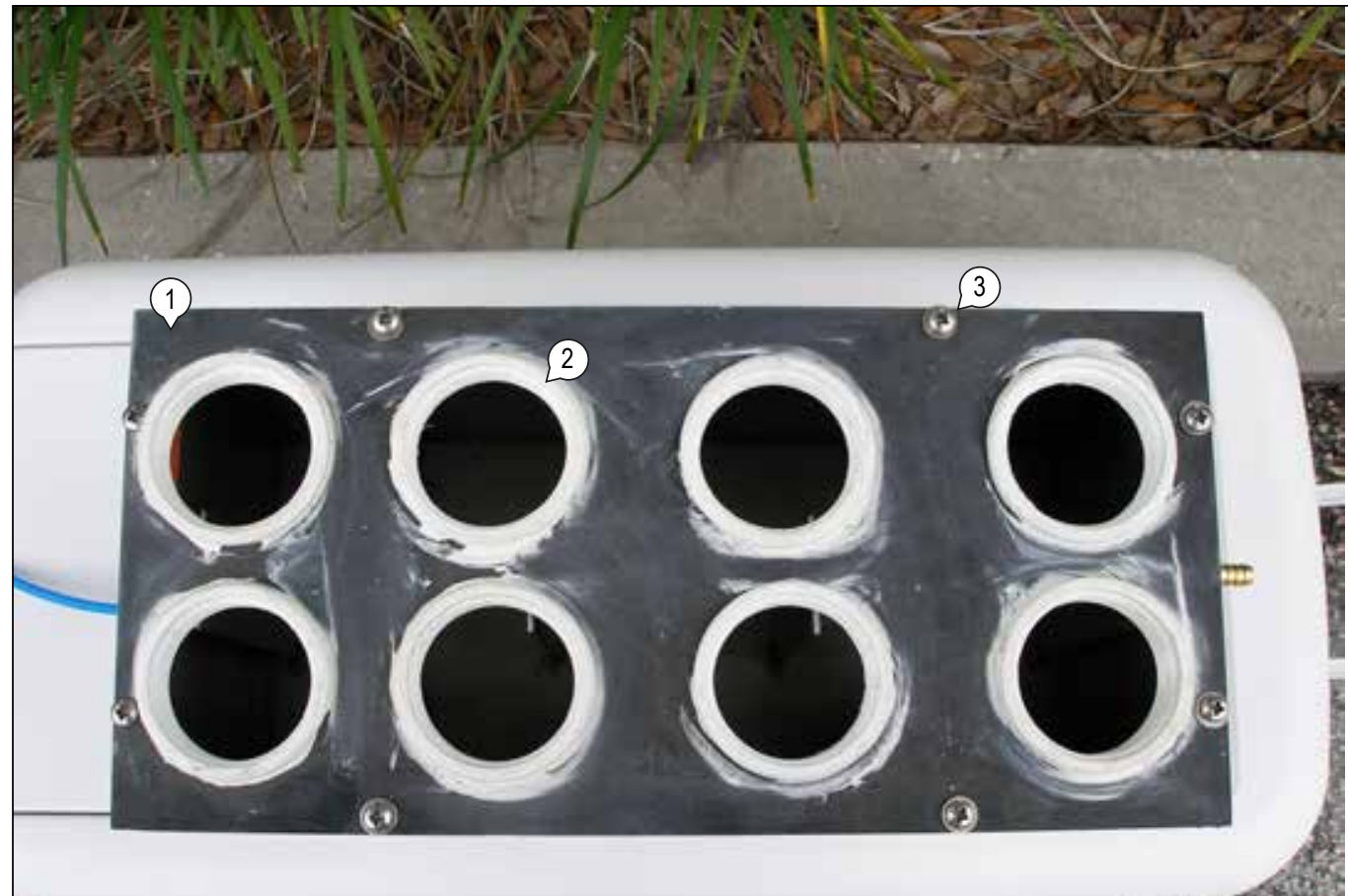

1. Inert polymer top

2. Threaded PVC insert for cap with diffusion chamber (see figure 1-4)

3. SS bolts to secure polymer top to SS flow cell

Figure 1-7. The stainless steel flow-through chamber showing the inert polymer top into which the caps that hold the diffusion chambers are inserted (top view). 


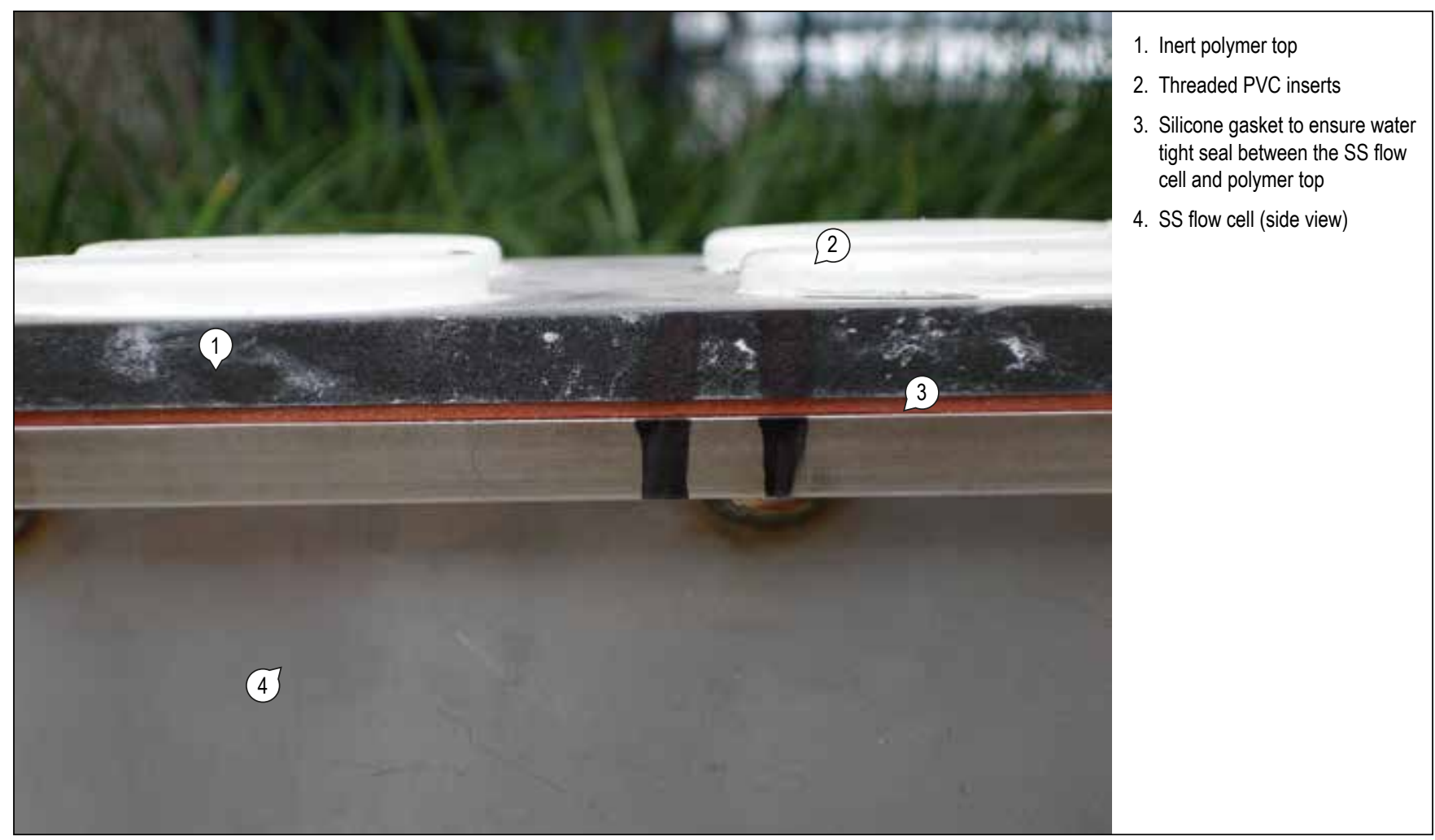

Figure 1-8. The stainless steel flow-through chamber showing the silicon gasket that seals the connection between the polymer top and the stainless steel chamber (side view). This gasket prevents the source water in the outer flow-through chamber from leaking into this chamber.

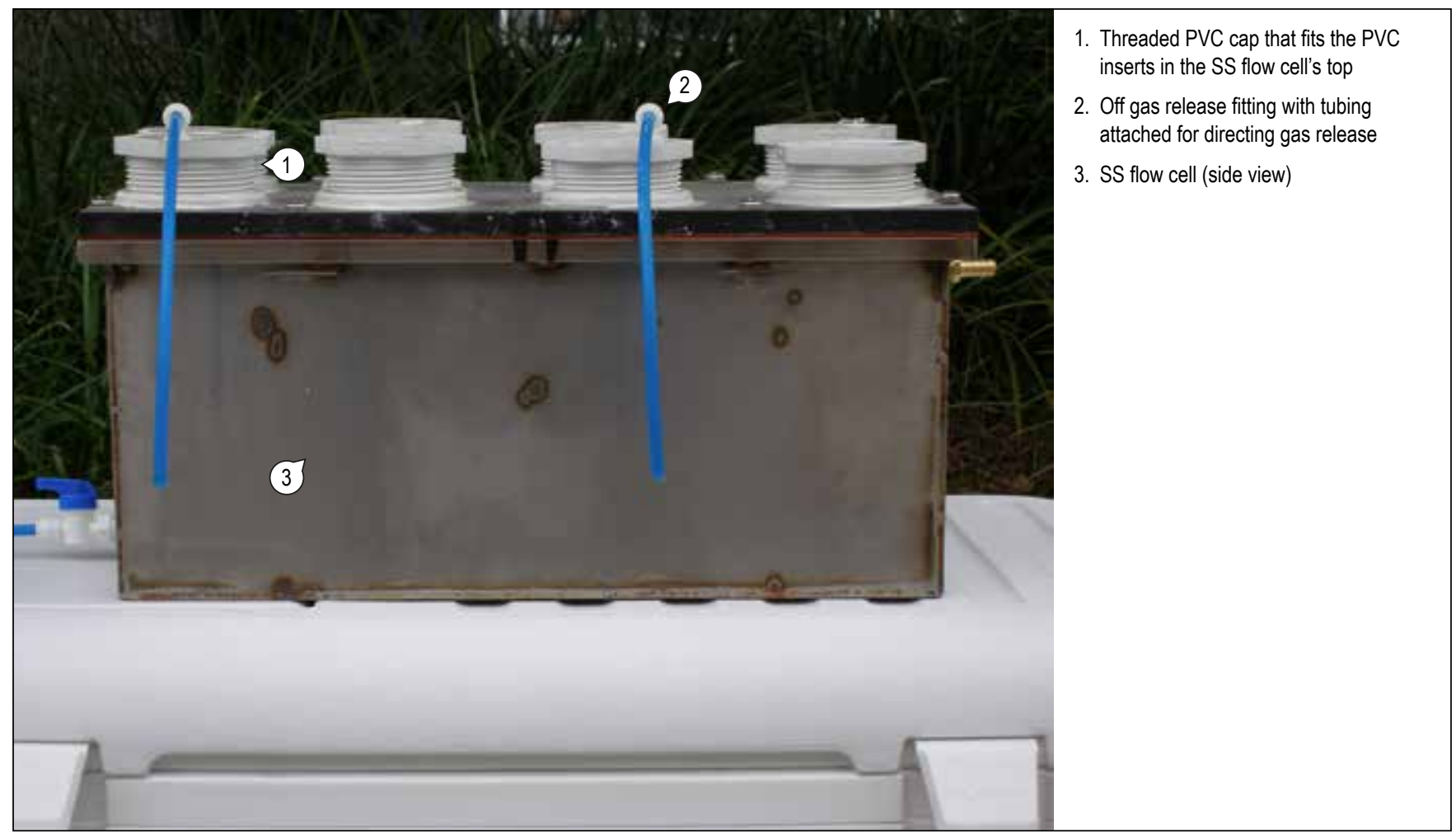

Figure 1-9. The complete stainless steel flow-through chamber with diffusion chambers inserted (side view). 


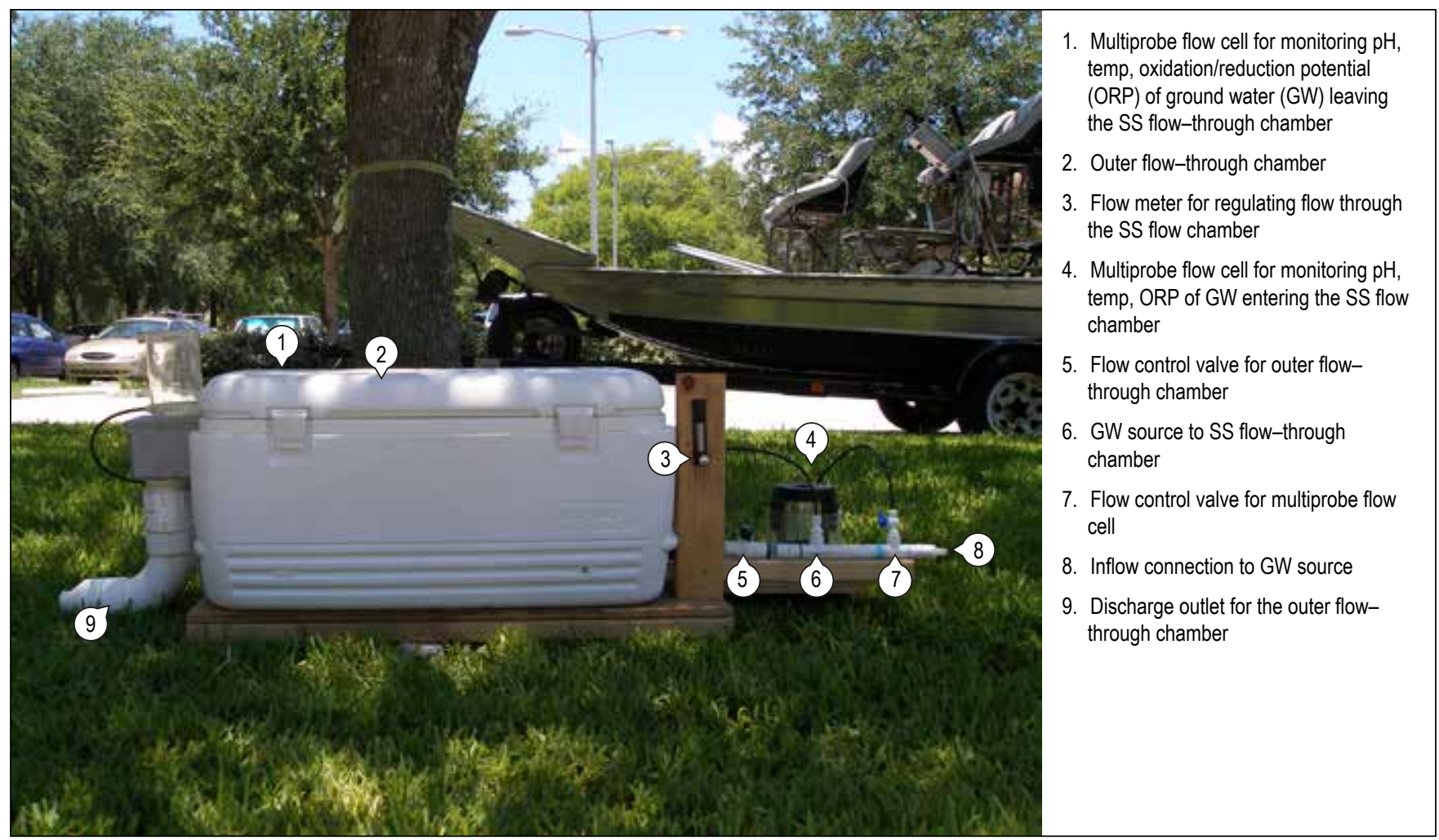

Figure 1-10. The outer flow-through chamber, flow rate controls and connections for the multiprobe attachment fittings.

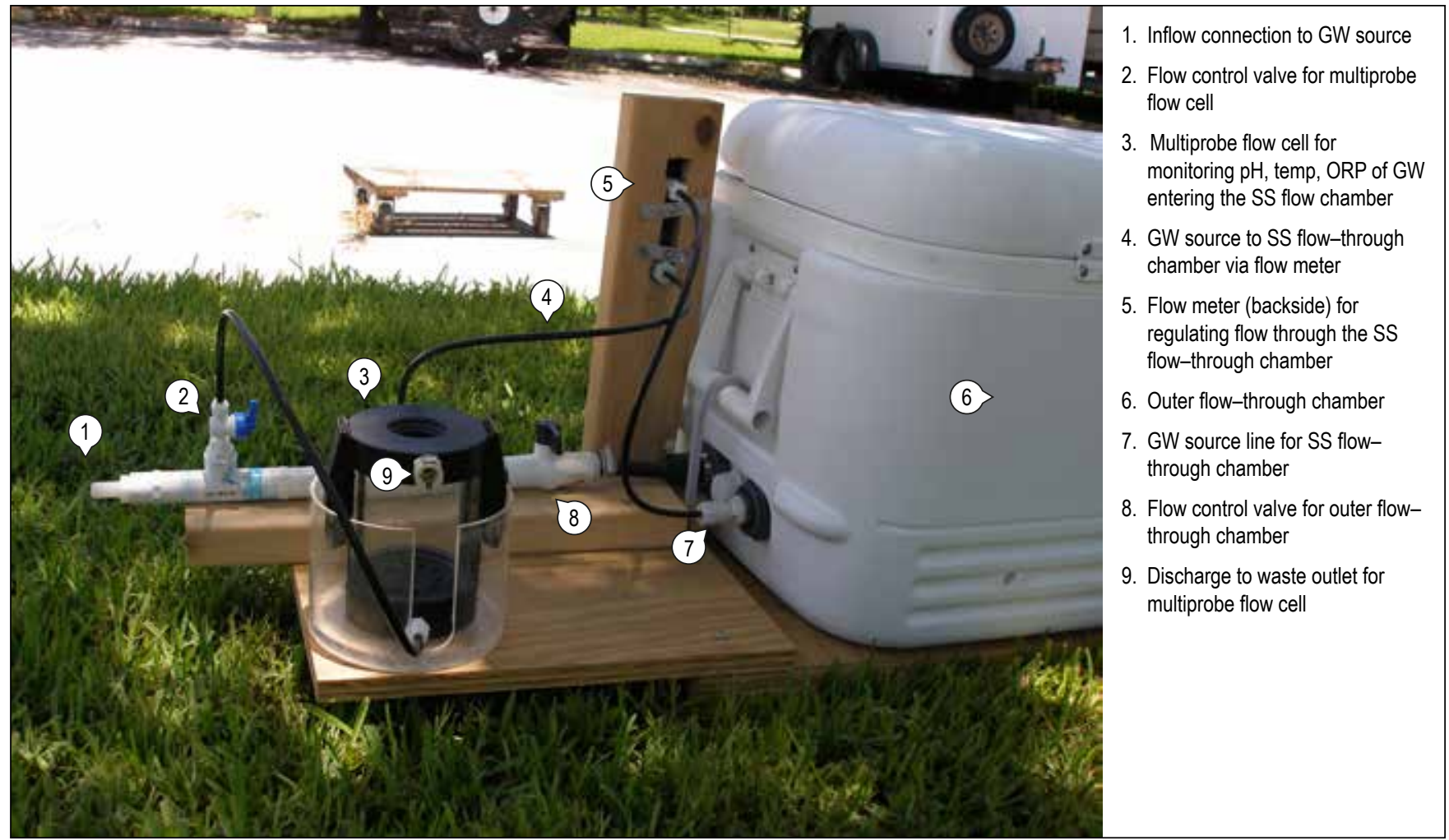

Figure 1-11. The outer flow-through chamber flow rate controls and multiprobe attachment fittings (rear view). 


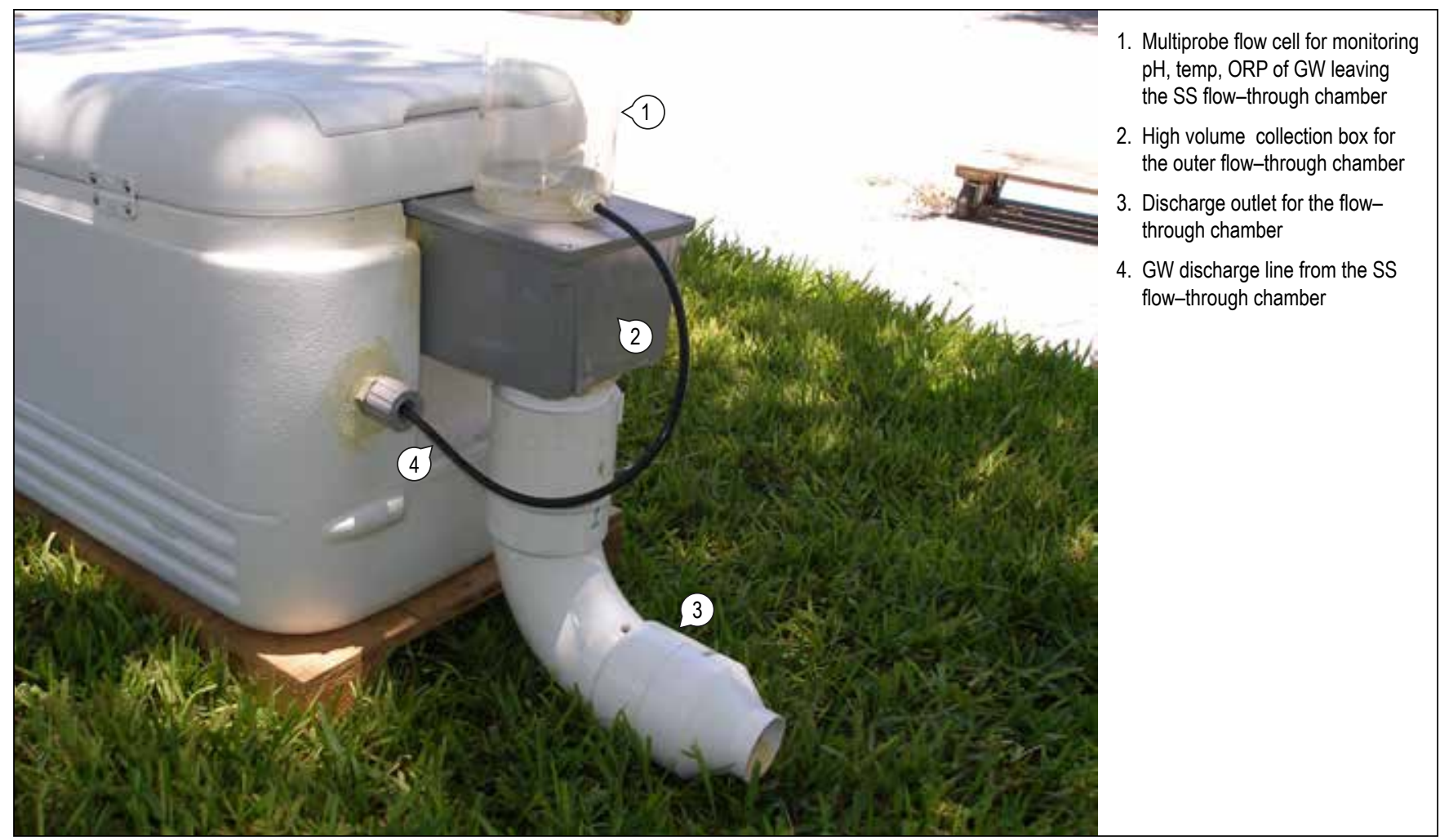

Figure 1-12. The outer flow-through chamber discharge and multiprobe fittings.

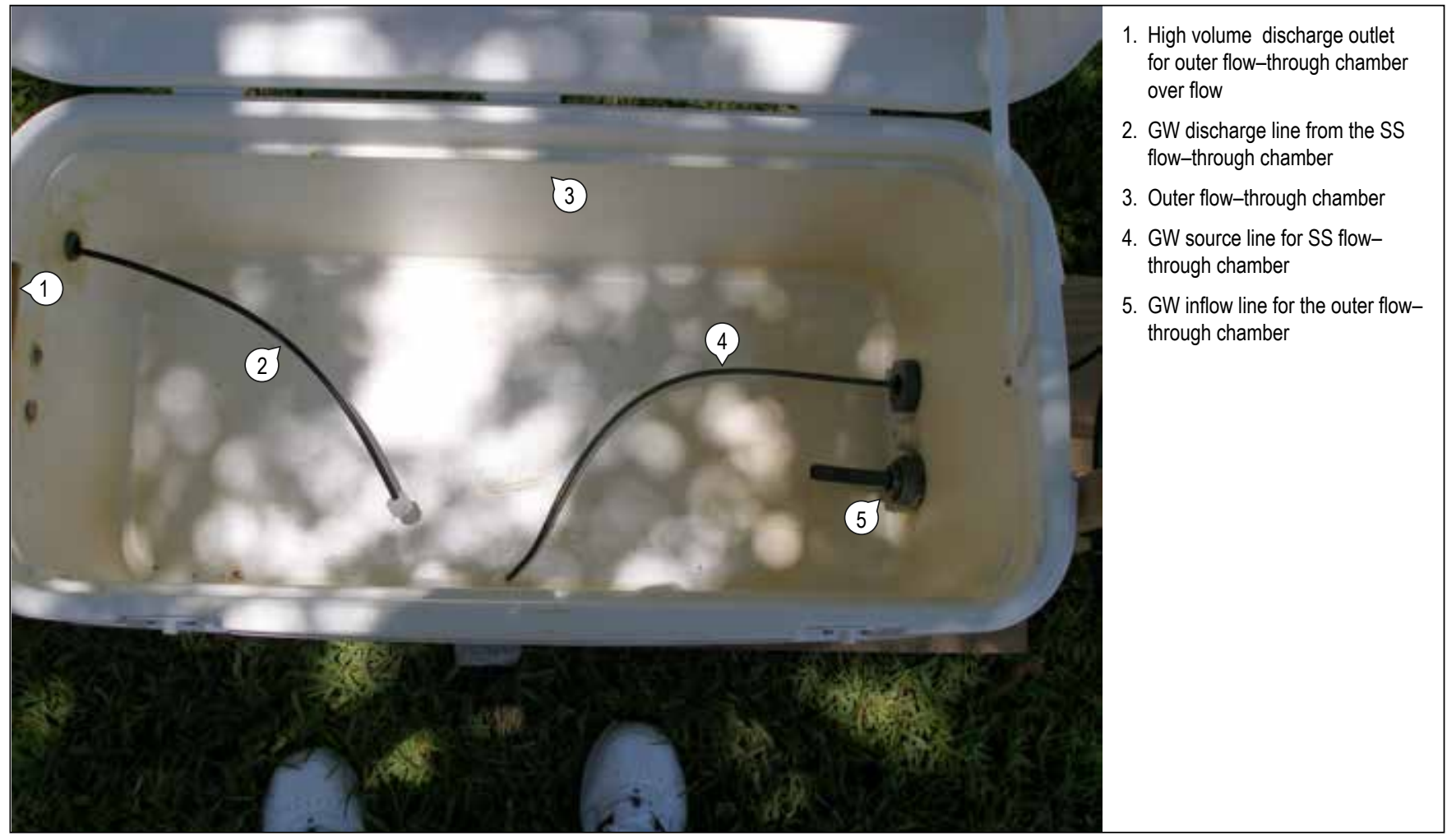

Figure 1-13. An empty outer flow-through chamber showing the connections for the stainless steel flow-through chamber that contains the diffusion chambers. 


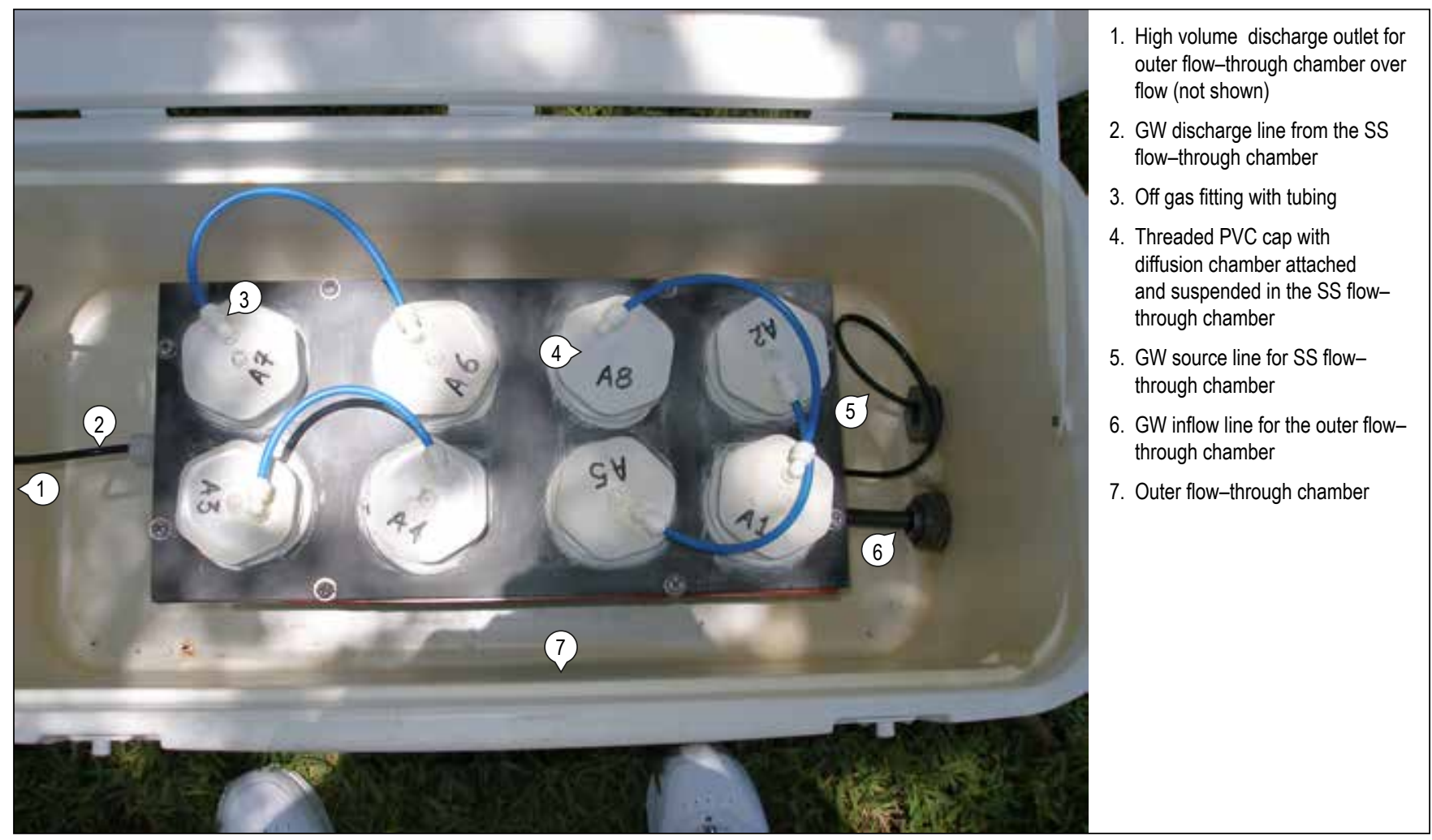

Figure 1-14. The complete aboveground flow-through microcosm.

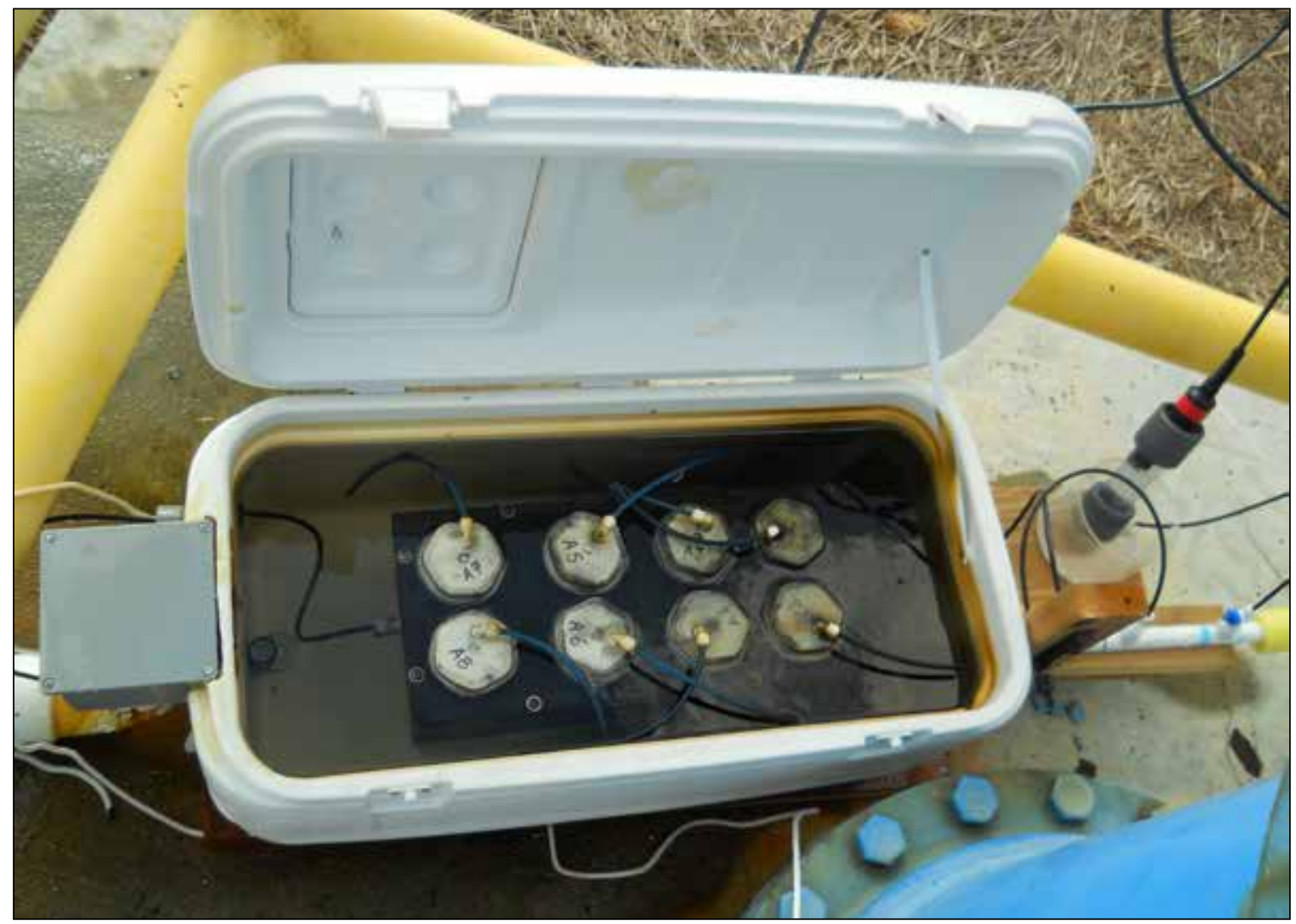

Figure 1-15. The above ground flow through microcosm in the field. 